\title{
UTILIZACÃO DE SORO DE QUEIJO NA DIGESTÃO ANAERÓBICA
}

\author{
Tais Helena Martins Lacerda \\ Quimica Industrial
}

Dissertação apresentada à Escola Superior de Agricultura "Luiz de Queiroz", da Universidade de São Pau1o, para obtenção de Título de Mestre em Agronomia, Ärea de Concentração: Tecnologia de Alimentos.

PIRACICABA

ESTADO dE SÃo PAUULO - BRASIL

DEZEMBRO/1987 
Lacerda, Ta is Helena Martins

L137u

Utilização do soro de queijo na digestão anaerōbica. Piracicaba, 1988.

$85 \mathrm{p}$.

Diss. (Mestre) - ESALQ

Bibliografia.

1. Digestão anaerōbica 2. Queijo - Subprodu to 3. Soro de queijo - Uso I. Escola Superior de Agricultura Luiz de Queiroz", Piracicaba. 


\section{UTILIZACÃO DE SORO DE QUEIJO NA DIGESTÃO ANAERÓBICA}

tais Helena Martins Lacerda

Aprovado em 08/02/1988.

Comissão JuTgadora:

Prof. Dr. Antonio Joaquim de 01 iveira - ESALQ/USP

Prof. Dr. Luiz Carlos Basso- ESALQ/USP

Prof. Dr. João Gustavo Brasil Caruso - ESALQ/USP

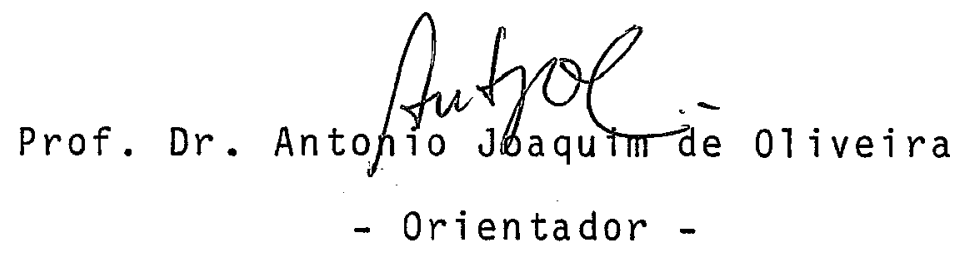


Aos meus pais

\section{OFEREÇO}

Ao meus sobrinhos e irmãos 
Ao Prof. Dr. Antonio Joaquim de 01 iveira

Ao Prof. Dr. João Gustavo Brasil Caruso

Ao Prof. Ms. Cläudio Rosa Gallo

Ao Prof. Dr. Paulo Roberto Cantarelli

Aos Engenhei ros Agrōnomos José Marcos Gryschek e Franklin Rosa Belo

A Drạ Rosana Novaes

A Secretäria Sandra de Marchi

As Tēcnicas Cleomar M. Carvalho, Ivani Moreno e Ana Maria Zani Moura

A Escola Superior de Agricultura "Luiz de Queiroz" da Universidade de São Paulo

Aos Professores do Curso de Pös-Graduação em Tecnologia de Alimentos da E.S.A. "Luiz de Queiroz" - USP

A BRASMETANO, Tecnologia Integradas

Ao Departamento de Tecnologia Rural da E.S.A. "Luiz de Quei roz"' - USP

A CETESB - Companhia de Tecnologia de Saneamento Ambiental. 


\section{INDICE}

Pägina

LISTA DE FIGURAS............................. $\mathrm{i} i \mathrm{i}$

LISTA DE TABELAS............................ v

RESUMO $\ldots \ldots \ldots \ldots \ldots \ldots \ldots \ldots \ldots \ldots \ldots \ldots \ldots \ldots \ldots \ldots \ldots \ldots \ldots \ldots$

SUMMARY $\ldots \ldots \ldots \ldots \ldots \ldots \ldots \ldots \ldots \ldots \ldots \ldots \ldots \ldots \ldots \ldots \ldots \ldots \ldots \ldots \ldots \ldots \ldots \ldots \ldots$

1. INTRODUÇÃO ............................... 1

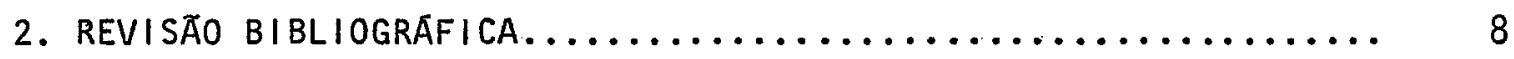

2.1. Generalidades......................... 8

2.2. Etapas da Biossintese de Metano................... 11

2.3. Parâmetros que Afetam a Digestão Anaeróbica............ 14

2.4. Tipos de Biodigestores...................... 17

2.4.1. Concepção convencional .................. 18

2.4.2. Concepção não-convencional .................. 19

2.4.2.1. Filtros anaeröbicos.............. 20

2.4.2.2. Biodigestores de contato........... 21

2.4.2.3. Biodigestor de fluxo ascendente....... 21

2.5. Digestão Anaeróbica do Soro de Queijo.............. 23

3. MATERIAIS E METOdos........................... 30

3.1. Materiais................................... 30

3.1 .1 . Biodigestores............................. 30

3.1.2. Inóculo.......................... 31

3.1.3. Substrato........................... 31

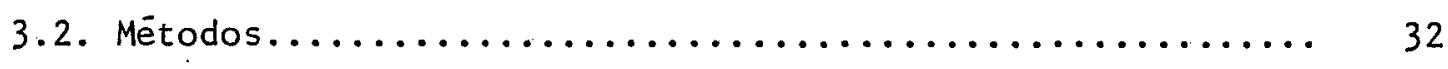

3.2.1. Condições gerais do experimento........... 32 
Pägina

3.2.2. Condução do experimento................ 34

3.2.2.1. Aclimatação do inōculo............ 34

3.2.2.2. Operação normal dos biodigestores...... 34

3.2.3. Parāmetros para acompanhar e avaliar o processo da digestão anaeröbica................... 35

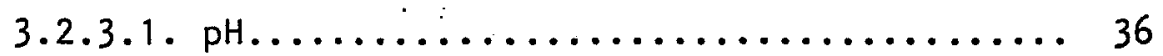

3.2.3.2. Volume de gases produzidos.......... 36

3.2.3.3. Composição de gases............... 36

3.2 .3 .4 . Ācidos voläteis...................... 37

3.2 .3 .5$. Alcal inidade................. 37

$3 \cdot 2 \cdot 3 \cdot 6$. Demanda química de oxigênio (DQO) ...... 38

4. RESULTADOS E DISCUSSÃO ....................... 40

4.1. Variação do pH, Acidez Volätil e Alcalinidade da Digestão Anaerōbica do Soro de Quei jo Com e Sem Correação de pH................................. 41

4.1.1. Biodigestores alimentados com soro sem correção

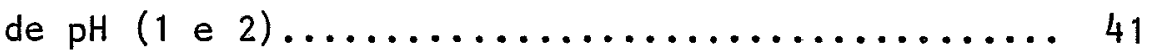

4.1.2. Biodigestores alimentados com soro com $\mathrm{pH}$ corrigi-

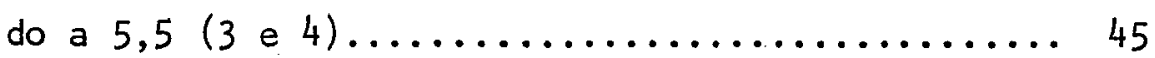

4.1.3. Biodigestores alimentados com soro com $\mathrm{pH}$ corrigi-

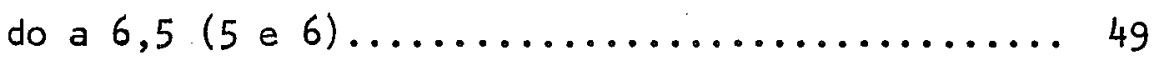

4.2. Eficiência da Digestão Anaerōbica do Soro de Queijo em Relação à Remoção de DQO e Produção de Biogās.......... 53

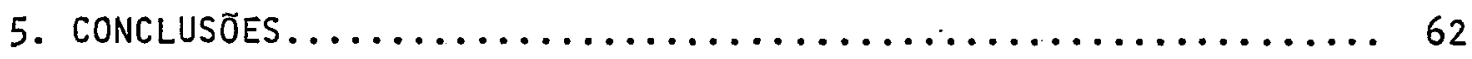

6. REFERENCIAS BIBLIOGRÄFICAS....................... 64

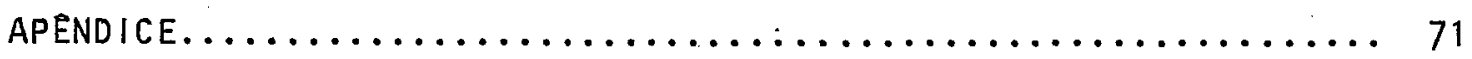




\section{LISTA DE FIGURAS}

Pāgina

Figura 1: Esquema de 3 estägios da digestão anaeröbica........ 12

Figura 2: Esquema do biodigestor convencional............. 19

Figura $3:$ Filtro anaerōbico...................... 20

Figura 4: Esquema do biodigestor de contacto.............. 21

Figura $5:$ Biodigestor tipo fluxo ascendente.............. 22

Figura 6: Esquema do biodigestor utilizado.............. 30

Figura 7: Esquema do sistema utilizado no experimento........ 33

Figura 8: Valores de $\mathrm{pH}(-)$, acidez volātil expressa em $\mathrm{mg}$ $\mathrm{CH}_{3} \mathrm{COOH} / 1$ (--) e alcalinidade expressa em $\mathrm{mg} \mathrm{CaCO}_{3} / 1$

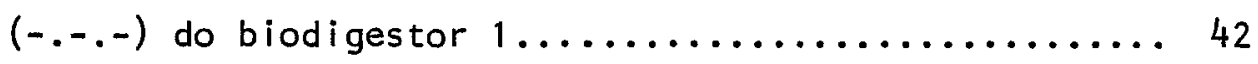

Figura 9: Valores de $\mathrm{pH}(-)$, acidez volätil expressa em $\mathrm{mg}$ $\mathrm{CH}_{3} \mathrm{COOH} / 1$ (--) e alcalinidade expressa em $\mathrm{mg} \mathrm{CaCO}_{3} / 1$

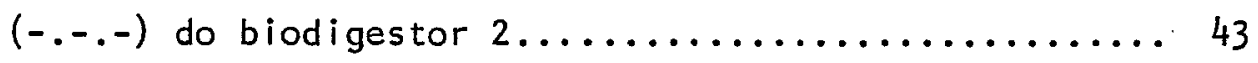

Figura 10: Valores de $\mathrm{pH}(-)$, acidez volātil expressa em mg $\mathrm{CH}_{3} \mathrm{COOH} / 1$ (--) e alcalinidade expressa em $\mathrm{mg} \mathrm{CaCO}_{3} / 1$ $(-.-$.$) do biodigestor 3 \ldots \ldots \ldots \ldots \ldots \ldots \ldots \ldots \ldots$

Figura 11: Valores de $\mathrm{pH}(-)$, acidez volätil expressa em $\mathrm{mg}$

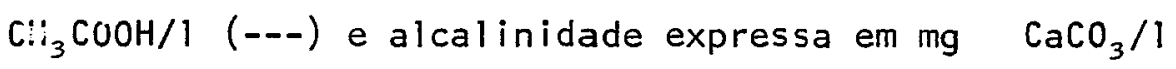
$(-. .-)$ do biodigestor $4 \ldots \ldots \ldots \ldots \ldots \ldots \ldots \ldots . \ldots . \ldots 48$

Figura 12: Valores de $\mathrm{pH}(-)$, acidez volätil expressa em $\mathrm{mg}$ $\mathrm{CH}_{3} \mathrm{COOH} / 1$ (--) e alcalinidade expressa em $\mathrm{mg} \mathrm{CaCO}_{3} / 1$

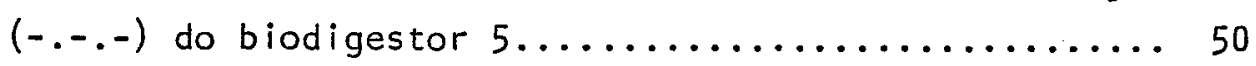


Figura 13: Valores de $\mathrm{pH}(-)$, acidez volātil expressa em $\mathrm{mg}$ $\mathrm{CH}_{3} \mathrm{COOH} / 1$ (--) e alcalinidade expressa em $\mathrm{mg} \mathrm{CaCO}_{3}$ $(-.-$.$) do biodigestor 6 \ldots \ldots \ldots \ldots \ldots \ldots \ldots \ldots \ldots \ldots \ldots$

Figura 14: Produção de biogás $(-)$, teor de metano no biogás (-) e grama de DQO removida em função do tempo (-.-.-) ut $1 \mathrm{izando} 5,38 \mathrm{~g} \mathrm{DQO} / \mathrm{dia}$ de soro, no biodigestor $1 \ldots \ldots$

Figura 15: Produção de biogäs ( $(-)$, teor de metano no biogās (--) e grama de DQO removida em função do tempo (-.-.-) utilizando $5,38 \mathrm{~g} \mathrm{DQO/dia} \mathrm{de} \mathrm{soro,} \mathrm{biodigestor.}$

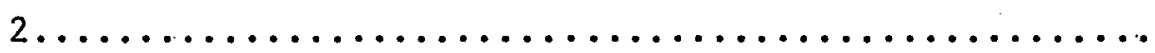

Figura 16: Produção de biogäs (-), teor de metano no biogās (---) e grama de DQO removida em função do tempo (-.-.-) utilizando $5,38 \mathrm{~g}$ DQO/dia de soro, no biodiges

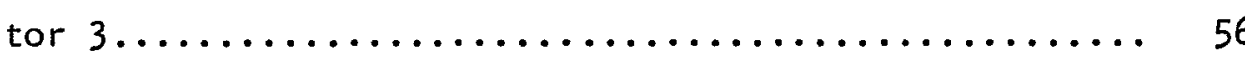

Figura 17: Produção de biogās ( $(-)$, teor de metano no biogās (--) e grama de DQO removida em função do tempo (-.-.-) utilizando $5,38 \mathrm{~g}$ DQO/dia de soro, no biodiges

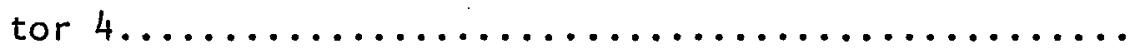

Figura 18: Produção de biogās $(\longrightarrow)$, teor de metano no biogās (--) e grama de DQO removida em função do tempo (-.-.-) utilizando $5,38 \mathrm{~g}$ DQO/dia de soro, no biodiges

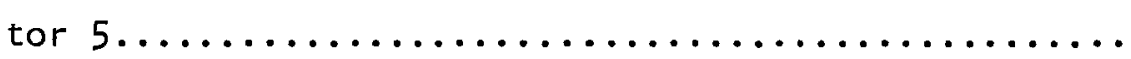

Figura 19: Produção de biogās (-), teor de metano no biogās (--) e grama de DQO removida em função do tempo (-.-.-) utilizando $5,38 \mathrm{~g} \mathrm{DQO/dia}$ de soro, no biodiges

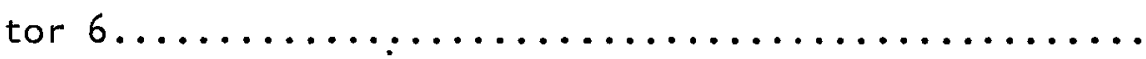




\section{LISTA DE TABELAS}

Pägina

Tabela 1: Composição química percentual do soro para caseína e

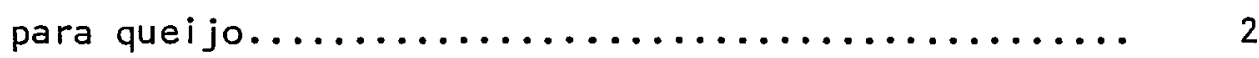

Tabela 2: Equivalência de $1 \mathrm{~m}^{3}$ de biogás $\left(5.000 \mathrm{kcal} / \mathrm{m}^{3}\right) \ldots \ldots$

Tabela 3: Quantidade mëdia de găs produzido a partir de diferen

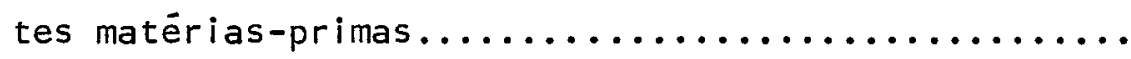

Tabela 4: Anälises físico-químicas do soro de queijo..........

Tabela 5: Tratamentos utilizados no ensaio................

Tabela 6: Sistemas de alimentação utilizado em cada TR........

Tabela 7: Acidez voláti 1, alcalinidade e pH dos biodigestores 1

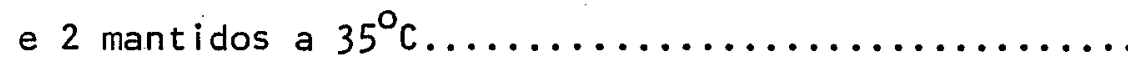

Tabela 8: Acidez volätil, alcalinidade e pH dos biodigestores 3 e 4 mantidos a $35^{\circ} \mathrm{C}$

Tabela 9: Acidez volätil, alcalinidade e pH dos biodigestores 5 e 6 mantidos

a $35^{\circ} \mathrm{C}$

Tabela 10: Remoção de DQO obtida na digestão anaerōbica do soro de queijo utilizando uma carga diäria de $5,38 \mathrm{~g}$ DQO nos biodigestores 1 e $2 \ldots \ldots \ldots \ldots \ldots \ldots \ldots \ldots \ldots$

Tabela 11: Remoção de DQO obtida na digestão anaeróbica do soro de queijo utilizando uma carga diäria de $5,38 \mathrm{~g}$ DQO nos biodigestores 3 e $4 \ldots \ldots \ldots \ldots \ldots \ldots \ldots \ldots \ldots \ldots \ldots \ldots \ldots \ldots$ 
Tabela 12: Remoção de DQO obtida na digestão aneróbica do soro de queijo utilizando uma carga diäria de $5,38 \mathrm{~g}$ DQO nos biodigestores 5 e $6 \ldots \ldots \ldots \ldots \ldots \ldots \ldots \ldots \ldots$

Tabela 13: Produção de biogás (1) nos biodigestores $1,2,3,4$, 5 e 6 mantidos à temperatura de $35^{\circ} \mathrm{C}$ e al imentados com $5,38 \mathrm{~g} \mathrm{DQO} / \mathrm{dia}$ no primeiro tempo de retenção........

Tabela 14: Produção de biogās (1) nos biodigestores 1, 2, 3, 4, 5 e 6 mantidos à temperatura de $35^{\circ} \mathrm{C}$ e alimentados com $5,38 \mathrm{~g} \mathrm{DQO} / \mathrm{dia}$ no primeiro tempo de retenção.....

Tabela 15: Produção de biogās (1) nos biodigestores $1,2,3,4$, 5 e 6 mantidos à temperatura de $35^{\circ} \mathrm{C}$ e alimentados com $5,38 \mathrm{~g} \mathrm{DQO/dia} \mathrm{no} \mathrm{primeiro} \mathrm{tempo} \mathrm{de} \mathrm{retenção....}$

Tabela 16: Produção de biogás (1) nos biodigestores $1,2,3,4$, 5 e 6 mantidos à temperatura de $35^{\circ} \mathrm{C}$ e alimentados com $5,38 \mathrm{~g}$ DQO/dia no primeiro tempo de retenção....

Tabela 17: Eficiência da digestão anaeróbica de soro de queijo sem correção de $\mathrm{pH}$ a $35^{\circ} \mathrm{C}$ (Biodigestores 1 e 2).....

Tabela 18: Eficiência da digestão anaeróbica de soro de queijo sem correção de $\mathrm{pH}$ a 5,5 e mantidos a $35^{\circ} \mathrm{C}$ (Biodiges

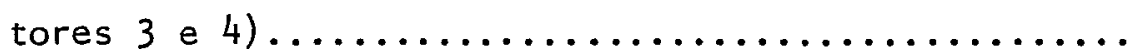

Tabela 19: Eficiência da digestão anaeróbica de soro de queijo com correção de $\mathrm{pH}$ a 6,5 e mantidos a $35^{\circ} \mathrm{C}$ (Biodiges

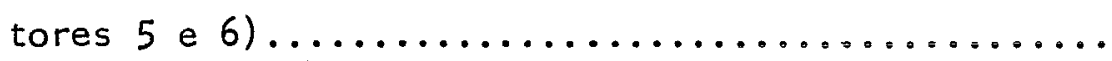

Tabela 20: Remoção total de DQO em cada TR mantidos a $35^{\circ} \mathrm{C}$ e uti

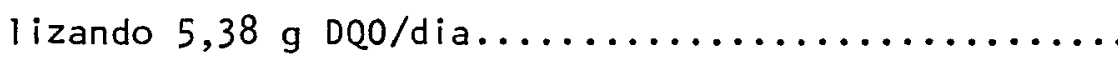




\section{UTILIZAÇ̃̃O DE SORO DE QUEIJO NA DIGESTÃO ANAERÓBICA}

Autora: TAIS HELENA MARTINS LACERDA Orientador: Prof. Dr. ANTONIO JOAQUIM DE OLIVEIRA

\section{RESUMO}

o principal objetivo deste trabalho consistiu em avaliar a digestão anaeröbica do soro de quejo $(68.000$ $\mathrm{mg} D Q 0 / 1)$ com e sem correção de $\mathrm{pH}$ utilizando bicarbonato de sōdio, em digestores semicontínuos de escala laboratorial e mantidos à temperatura de $35^{\circ} \mathrm{C}$.

Foi utilizado como inōculo esterco bovino, com teor de sölidos totais igual a $8 \%$.

o experimento foi desenvolvido num período de 100 dias, onde os primeiros 20 dias foram caracterizados pela aclimatação do inóculo e quatro tempos de retenção (TR) de 20 dias. Uma carga mäxima de al imentação de 5,38 g DQO/dia foi adicionada a cada digestor.

No 19TR a alimentação foi adicionada nos digestores em intervalos de 8 horas. No $29 T R$ a carga foi dividida em 2 partes e adicionada aos digestores em interva- 
los de 12 horas. No 39 TR intervalos de 6 horas para a alimentação foi utilizado, com a divisão da carga em 4 partes. 0 49TR foi caracterizado pela alimentação sem divisão da carga nos digestores.

Para um controle do experimento, anälises de ácidos graxos voläteis, alcalinidade e pH, juntamente com a produção de biogās foram realizadas. A composição do biogās foi determinada em cromatōgrafo a gäs com coluna Porapak $N$ e anälise da demanda química de oxigênio (DQO) no efiuente foi tambëm determinada.

Os resultados do presente trabalho mostram que o sistema de alimentação afetou o desenvolvimento da digestão anaeróbica, e consequentemente a produção de metano. A māxima produção de metano foi obtida quando se fez a correção do $\mathrm{pH}$ do soro de alimentação e não houve diferença entre os dois níveis de correção do $\mathrm{pH}(5,5$ e 6,5$)$. 


\title{
ANAEROBIC DIGESTION UTILIZING CHEESE WHEY
}

\author{
Author: TAIS HELENA MARTINS LACERDA \\ Adviser: Prof. Dr. ANTONIO JOAQUIM DE OLIVEIRA
}

\section{SUMMARY}

The main objetive of this work was to evaluate the anaerobic digestion of cheese whey. $(68.000 \mathrm{mg}$ DQ0/1) with and without correction of the whey pH by sodium bicarbonate, in semi-continous laboratory soad digestors with the temperature kept at $35^{\circ} \mathrm{C}$.

$$
\text { A cattle seed manure was utilized with } 8 \%
$$

total solids.

The experiment was developed in a period of 100 days, in which the first 20 days period was characterized for acclimatization of seed manure and four 20 days hidraulic retention times. A maximum loading of $5,38 \mathrm{~g}$ DQO/day was feed to each digestor.

In the first hidraulic retention time the loading was feed to the digestors at intervals of 8 hours. In the second hidraulic retention time the loading was divided in two portions and feed to the digestors at intervals of 12 hours. For the third retention time a 6 hours 
interval for feeding. were used, being the loading divided in four portions. The forth retention time was characterized by feeding the total loading. in the digesters only once.

For a experimental control, volatile fatty acids, alkalinity, $\mathrm{pH}$ and the volume of biogas produced were monitored. The biogas composition was determined by gas chromatography using a Porapak $N$ column. The chemical oxigen demand (COD) in the effuent was also mearured.

The results obtained show that there was some influence of the feeding: systems on the anaerobic digestion of the whey and also on the metane production. The maximum methane production was achieved when the feeding whey had the $\mathrm{pH}$ corrected and there was no difference between the levels of $\mathrm{pH}$ correction $(5,5$ and 6,5$)$. 


\section{INTRODUÇÃO}

o soro de queijo é um residuo altamente poluidor obtido da fabricação de queijos e caseína.

A produção de soro depende principalmente da manufatura e do tipo de queijo produzido, que corresponde a aproximadamente 91 de soro por $\mathrm{kg}$ de queijo; deste modo as regiōes que contém laticínios possuem um grande problema em relação a disposição final do resíduo (BARFORD et alii, 1986; ZEIKUS, 1986).

No Brasil, a demanda de queijos para o ano de 1984 foi estimada em 225.590 toneladas, correspondendo a uma disponibilidade de 2.000 .000 toneladas de soro (INDI, 1981).

O soro de queijo contém parte das proteinas do leite (lactoalbumina e lactoglobulina), a maioria das vitaminas hidrossolúveis (riboflavina e tiamina), lactose e alguns sais minerais (BARFORD et alii, 1986); a poluição que - soro causa é devida principalmente à lactose, responsāvel por $80 \%$ desta polui ção contra $20 \%$ devida à fração protéica (FERRAT, 1980). Na Tabela $1 \vec{e}$ apresentada a composição química do soro. 
Tabela 1: Composição química percentual do soro para caseína e para queijo

\begin{tabular}{lcc}
\hline \multicolumn{1}{c}{ Componentes } & Soro para caseina \% & Soro para quei jo \% \\
\hline Lactose & 4,6 & 4,9 \\
Ácido lä́tico & 0,4 & 0,2 \\
Cinzas & 0,7 & 0,6 \\
Proteínas & 0,9 & 0,9 \\
Gordura & 0,1 & 0,3 \\
\hline Matéria seca total & 6,7 & 6,9 \\
Âgua & 93,3 & 93,1 \\
\hline
\end{tabular}

Fonte: BYLUND (1975)

Se este soro for descartado em cursos d'água, prätica comum em muitas Indüstrias, constituir-se-ä em um dos mais potentes resíduos industriais, devido a sua elevada demanda química de oxigênio $(D Q 0=60.000$ a $80.000 \mathrm{mg} / 1)$, passando a ser um problema adicional para as industrias de laticínios, alēm da grande perda representada pelo seu descarte (VIEIRA et alii, 1985).

Vārios mētodos para tratamento e utilização do soro vem sendo propostos a fim de reduzir o nível de poluịão, que estão descritos à seguir:

- Secagem do soro para utilizaça como ali-. 
mento animal ou aditivo alimentar (KOSIKOWSKI, 1967); entretanto a quantidade de energia gasta para a secagem torna-o anti-econômico;

- Recuperação da lactose por cristalização e futura utilização em alimentos infantis e produtos farmacēuticos; mas os mercados são bastante limitados e geralmente utilizam outros carboidratos mais baratos (BARFORD et alii, 1986).

- Recuperação de proteína e lactose por osmose reversa ou por ultrafiltração (ZEIKUS, 1986); estes processoṣ são anti-econômicos e geralmente ocorre contaminações nas proteinas;

- Produção de proteína microbiana ou fermentação alcoölica (IZAGUIRRE \& CASTILHO, 1982, 1986; REESEN \& STRUBE, 1978); esses processos requerem secagem do soro no armazenamento para utilização como substrato, o que não ocorre com outros substratos alternativos como o melaço.

Dos tratamentos citados anteriormente, exceto de osmose reversa, continuam gerando efluentes com elevadas cargas poluidoras e em alguns casos para a disposição do resíduo final hà necessidade de tratamentos auxiliares.

Os sistemas de tratamento biológico de resíduos (aeröbicos, anaeröbicos ou em conjunto), vem sendo bas- 
tánte utilizado. A degradação aeröbica consiste na. conversão bacteriana do material orgānico em produtos finais sölidos, em contraste com a degradação anaeróbica que converte os poluentes via uma sērie de reações metabölicas em produtos finais gasosos, principalmente metano e diöxido de carbono que pode ser utilizado como fonte de energia (DIETCHFIELD, 1986).

No Brasil, os mētodos convencionais de tratamento de residuos líquidos industriais são basicamente aeróbicos, apesar de incluir uma fase anaeröbica de digestão de sólidos, separados durante o tratamento aeróbico. Os processos aeröbicos que vêm sendo utilizados são as plantas de lodo ativado (mas que as tornam inviävel economicamente para o tratamento de resíduos líquidos com elevado teor de matéria orgânica como o soro de queijo, porque requerem grandes quantidades de energia para a aeração e agitação) e lagoas de estabilização (CEREDA et alii, 1986).

A digestão anaerōbica de resíduos industriais líquidos oferece um excelente controle de poluição e produz energia alternativa, o biogàs, o qual poderá abastecer parte da energia necessária à instalação, como aquecimento de caldeiras, acionar motores e geradores (energia elétrica) etc., assim competindo diretamente com os derivados do petróleo e energia elētrica (LO \& LIAO, 1986a).

Na Tabela 2 é mostrado a equivalência de $1 \mathrm{~m}^{3}$ de biogās com poder calorifico superior a $5.000 \mathrm{kcal} / \mathrm{m}^{3}$, com 
outros combustiveis.

Tabela 2: Equivalência de $1 \mathrm{~m}^{3}$ de biogās $\left(5.000 \mathrm{kcal} / \mathrm{m}^{3}\right)$

\begin{tabular}{|c|c|c|c|c|}
\hline Combustivel & Peso específico & $\begin{array}{c}\operatorname{rCS} * \\
(\mathrm{kcal} / \mathrm{kg})\end{array}$ & $\begin{array}{l}\text { Quantida } \\
\text { equivale }\end{array}$ & $\begin{array}{l}\text { lade } \\
\text { ente }\end{array}$ \\
\hline Gasolina & 0,73 & 11.100 & 0,62 & 1 \\
\hline Querosene & 0,79 & 10.900 & 0,58 & 1 \\
\hline ôleo díesel & 0,82 & 10.900 & 0,56 & 1 \\
\hline $\begin{array}{c}\text { Gás liquefeito } \\
\text { de petróleo }\end{array}$ & 0,54 & 11.90 .0 & 0,42 & 1 \\
\hline Gäs encanado & - & $4.750\left(\mathrm{kcal} / \mathrm{m}^{3}\right)$ & 1,05 & $m^{3}$ \\
\hline oleo combustível & 0,96 & 10.400 & 0,48 & $\mathrm{~kg}$ \\
\hline Lenha & - & 3.250 & 1,54 & $\mathrm{~kg}$ \\
\hline Carvão vegetal & - & 6.790 & 0,74 & $\mathrm{~kg}$ \\
\hline Etanol & $\cdot \quad-$ & 7.100 & 0,7 & $\mathrm{~kg}$ \\
\hline Metanol & - & 5.400 & 0,93 & $\mathrm{~kg}$ \\
\hline$x$ is to & - & 1.458 & 3.43 & $\mathrm{~kg}$ \\
\hline
\end{tabular}

Fonte: DANESE (1981)

E de fundamental importância, reduzir os preços de energía atravēs da substituição parcial ou total por fontes de baixo custo. No período de 1980 a 1983 , cerca de 300 biodigestores a nível de produção rural foram instalados no Brasil (SILVA, 1984); com isso a energia obtida a partir de resíduos agrícolas conseguiu suprir parte da energia necessāria nestes locais. 
A quantidade de gás produzida, assim como a sua composição, depende das condições em que se realiza o processo e o tipo de substrato utilizado (DANESE, 1981).

Na Tabela 3 são mostradas as quantidades médias de gás produzidas a partir de diferentes matérias-primas.

Tabela 3: Quantidade média de gäs produzido a partir de diferentes matérias-primas

\begin{tabular}{lc}
\hline Residuo & $m^{3}$ biogás/ton residuo \\
\hline Lodo primário & $28 *$ \\
Lixo (parte orgānica) & $75 *$ \\
Lixo + lodo primärio $(80: 20)$ & $155 \%$ \\
Esterco bovino & $38 *$ \\
Esterco de galinha & $62 * \%$ \\
Esterco suíno & $78 \%$ \\
Vinhaça & $10 \%$ \\
Rama de mandioca + esterco bovino $(80: 20)$ & $70 *$ \\
\hline
\end{tabular}

* Resultados do IPT (Instituto de Pesquisas Tecnológicas) ** Techniche Universität Berlin

Fonte: DANESE (1981)

Atravēs de estudos detalhados da digestão anaeróbica do soro de queijo em escala laboratorial e posteriormente em plantas piloto, poder-se-á então avaliar o 
potencial de produção de energia desse subproduto da indūstria de laticínios, visando a implantação de projetos em escala industrial. 


\title{
2. REVISÃO BIBLIOGRÁFICA
}

\author{
2. 1. Generalidades
}

A digestão anaeróbica vem sendo utilizada a quase 100 anos no tratamento de resíduos, principalmente lodo de esgoto. Na atualidade, poucas informações químicas e microbiológicas sobre este processo fermentativo são disponiveis, embora pesquisas neste campo venham aumentando nas ültimas décadas (CEREDA, 1986).

No Brasil, os estudos com biogás foram iniciados de maneira mais intensa a partir de 1976, entretanto, os resultados: alcançados asseguram um bom domínio tecnológico, concluindo que estamos qualificados a desenvolver um vasto programa a nivel nacional combiogás, tanto no setor agrícola como no industrial (BATISTA, 1981).

0 processo da digestão anaeróbica, consiste na degradação de compostos orgânicos em substâncias mais simples como metano $\left(\mathrm{CH}_{4}\right)$ e diōxido de carboño $\left(\mathrm{CO}_{2}\right)$, através da interação de diferentes microrganismos que atuam na ausência de oxigènio (GONÇALVES, 1982). 
Segundo HUGHES, (1980) e costA (1986), dos tratamentos biológicos de residuos, a digestão anaeróbica concorre com très aspectos relevantes:

- Estabilização do material orgânico pela degradação das moléculas, onde faz com que haja uma diminuição da poluição (reduções DQO e DBO);

- Produção de biogãs, fonte alternativa de energia, pela metabolização do substrato;

- Produção do biofertilizante.

A composição volumētrica do biogás proveniente dos biodigestores varia entre 50 a $70 \%$ de metano e entre 30 e $50 \%$ de diöxido de carbono, contendo ainda pequenas quantidades de hidrogênio $\left(\mathrm{H}_{2}\right)$, amónia $\left(\mathrm{NH}_{3}\right)$, vapor d'água no estado saturado e traços de sulfeto de hidrogênio $\left(H_{2} S\right)$. A quantidade de $\mathrm{CO}_{2}$ presente no gás reduz seu contẹ̣do' de energia, tornando seu custo de armazenagem mais dispendioso em relação ao metano puro; o biogás è muito pouco. solüvel em água, possibilitando assim seu aproveitamento como combustivel sem maiores tratamentos (DANESE, 1981).

o potencial de produção e utilização do biogäs deve ser analisado em função das disponibilidades locais das matērias-primas passiveis de serem transformadas. Em zonas rurais as matérias-primas disponíveis são as prove- 
nientes de dejetos animais e resíduos agrícolas, onde irão atender as necessidades energëticas bäsicas como cocção de alimentos, iluminação, geração de energia elétrica, etc.; nos centros urbanos, o 1 ixo e o esgoto doméstico, coletados diariamente representam o grande potencial de uso dos produtos resultantes, e o gás poderia ser encanado para suprir residências de bairros mais carentes; em indūstrias, o potencial de produção e consequente utilização de biogás depende da disponibilidade de efluentes biodegradáveis gerados em seus processos industriais. Dentre estas, destacam-se indústrias de açūcar e álcool, laticínios, matadouros, cervejarias etc. (DANESE, 1981).

ZINDER (1984) define alguns pontos preliminares sobre a bioconversão do material a ser digerido em metano:

- Especificação metabōlica dos anaerōbicos. No caso de cultura pura de aeróbicos, a mineralização da celulose a $\mathrm{CO}_{2}$ é completa, porēm a conversão anaeróbica da celulose ou outros compostos em $\mathrm{CH}_{4}$ e $\mathrm{CO}_{2}$ requer uma interação cooperativa de vārias espécies microbianas;

- A maior parte de energia livre presente: no substrato pode ser verificada no metano que foi produzido;

- muitos dos mais importantes microrganismos envolvidos são estritamente anaeröbicos. 
2.2. Etapas da Biossíntese de Metano

0 processo da digestão anaerōbica envolve uma. grande variedade de microrganismos simbiöticos. Essas formas complexas de associações, metabolizam continuamente o material orgânico em metano e diōxido de carbono. Para a explicação deste processo, ạ digestão anaerōbica é dividida em três estāgios, como mostra a Figura 1 (DITCHFIELD, 1986 ; TOERIEN et ali i, 1970).

Os trēs grandes grupos de microrganismos envolvidos nestes estägios são:

- Bactërias hidroliticas fermentativas, (1)

- Bactērias acetogénicas produtoras de hidrogênio, (11)

- Bactērias metanogēnicas (111)

o primeiro estägio envolve bactērias hidrolíticas fermentativas, que hidrolizam polissacarídeos, 1 ipídeos e proteínas a produtos mais simples como àcidos orgânicos (ácidos acético, propiônico e butírico), álcoois, $\mathrm{H}_{2}$ e $\mathrm{CO}_{2}$ (BRYANT, 1979).

o segundo estāgio envolve bactērias acetogênicas produtoras de hidrogênio, onde todos os ácidos graxos saturados (exceto o acetato) são oxidados nesta fase do processo a acetato e $\mathrm{H}_{2}$ e descarboxilam o propionato a ace- 


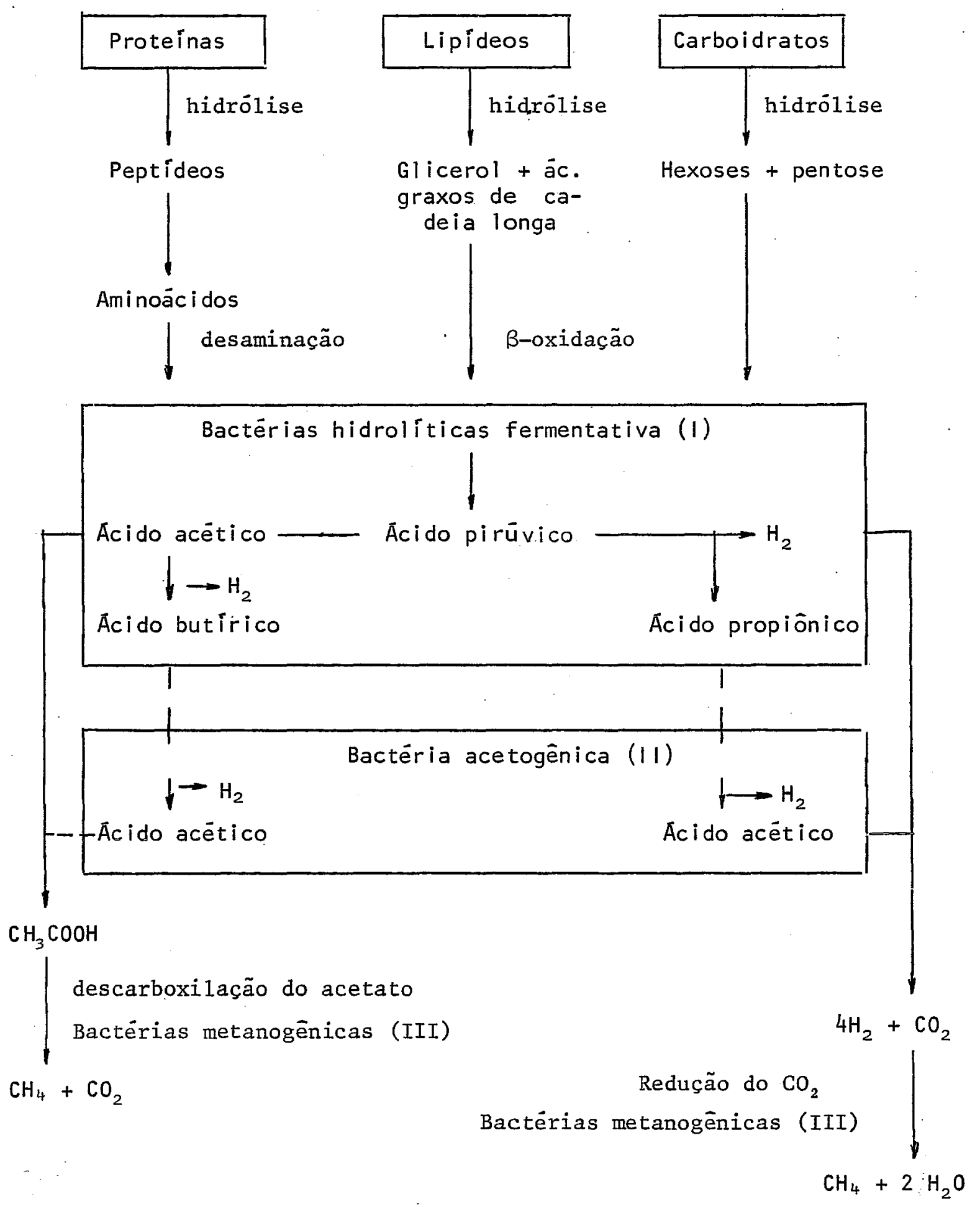

Figura 1: Esquema de 3 estāgios da digestão anaerōbica Fonte: DITCHEFIELD (1986) 
tato, $\mathrm{CO}_{2}$ e $\mathrm{H}_{2}$. Os álcoois formados no primeiro estágio são oxidados a acetato ou outros ácidos, dando produção de $\mathrm{H}_{2}$ (BRYANT, 1979; DITCHFIELD, 1986).

o terceiro estágio envolve as bactérias metanogênicas as quais utilizam os produtos do primeiro e segundo estágio $\left(\mathrm{H}_{2} / \mathrm{CO}_{2}\right.$ e/ou acetato $)$ na produção de $\mathrm{CH}_{4}$ e $\mathrm{CO}_{2}$. Este grupo de microrganismo è bastante heterogêneo em sua forma e estrutura, sendo a característica comum entre eles a forma de obtenção de energia para crescimento que leva a formação de metano. Estes necessitam de condições extremamente rigorosas de anaerobiose e podem crescer somente quando o potencial de redox do meio for menor que $-300 \mathrm{mV}$ (WOLFE, 1981; KUBIAK \& DUBUIS, 1985).

Suas necessidades nutricionais são bastante simples, sendo que a maioria requer alguns sais minerais, $\mathrm{CO}_{2}$, amônia como fonte de nitrogenio e sulfeto como fonte de enxofre. Algumas espécies requerem a adição de acetato, vitaminas do grupo B, 2 -metil butirato ou fatores de crescimento proveniente de líquido ruminal ou biodigestores de esgoto (BRYANT, 1979 \& PERES, 1982).

Dos grupos de microrganismos encontrados nos biodigestores, as bactérias metanogenicas são as mais susceptíveis à variações ambientais e possuem velocidades de crescimento bem baixas, o que torna limitante para o processo (DITCHFIELD, 1986). 
Cerca de $70 \%$ do metano formado nos biodigestores provēm da descarboxilação do acetato; esse nível pode aumentar de 4 a $6 \%$ com a hidrölise de lipideos e proteínas, isto é explicado pela reação acetogênica $\left(\mathrm{H}_{2}+\mathrm{CO}_{2} \rightleftarrows\right.$ Acetato $\left.+\mathrm{H}_{2} \mathrm{O}\right)$ (PERES, 1982; MAH et ali $\left.\mathrm{i}, 1977\right)$.

Atravēs de estudos obtidos por värios pesquisadores sobre a enumeraçăo das populaçōes bacterianas de biodigestores, foram encontradas bactērias hidrolíticas tota $1\left(10^{8}-10^{9} / \mathrm{ml}\right.$; a maioria bastonetes Gram negativos); bactērias proteolfticas $\left(10^{7 /} \mathrm{ml}\right.$; principalmente o gēnero Eubacterium); bactērias celulolíticas $\left(10^{5} / \mathrm{ml}\right.$, gênero clostridium); bactērias acetogênicas produtoras de hidrogênio $\left(10^{6} / \mathrm{m} 1\right.$, foram identificados bastonetes Gram negativos); bactérias homoacetogènicas $\left(10^{5}-10^{6} / \mathrm{ml}\right.$; os gêneros clostridium e Acetobacterium); e as bactērias metanogēnicas $\left(10^{6}-10^{8} / \mathrm{ml}\right.$, principalmente Methanobacterium, Methanospirillum, Methanosarcina e "Methanothrix". (ZEIKUS, 1977; ZEIKUS, 1980).

2.3. Parâmetros que Afetam a Digestão Anaeróbica

A digestāo anaerōbica è bastante sensível à variações ambientais, qualquer alteração que ocorra no processo acarretará desequilíbrios entre as populações bacterianas afetando diretamente o rendimento e a velocidade do processo (SOUZA, 1982a). 
PERES (1982) cita ser extremamente dificil analizar os efeitos químicos e físicos em qualquer sistema biolögico e em um biodigestor os principais parāmetros que devem ser constantemente analisados são: temperatura, pH, composição da matēria orgânica; taxa de alimentação e composição inorgânica do substrato.

A digestão anaeróbica pode se dar em temperaturas superiores a $10^{\circ} \mathrm{C}$ e inferiores a $65^{\circ} \mathrm{C}$. Nessas condições, a produção de metano tem duas situações ōtimas, uma em fase mesofílica em torno de $40^{\circ} \mathrm{C}$, a outra em zona termofillica em torno de $50-55^{\circ} \mathrm{C}$ (KUBIAK \& UUBUIS, 1985). SOUZA (1982a) relata ser extremamente importante manter a temperatura constante e operar sem variações significativas.

A faixa de pH ötima para o crescimento de muitos microrganismos se encontra entre 6,4 a 7,2 . Se houver uma diminuição do pH pode resultar numa elevação na concentração de ácidos graxos voláteis e portanto inibição da metanogēnese, se o pH estiver acima de 8,0 leva a uma maior formação de hidrogênio e amônia (BARKER, 1956). 0 equilíbrio do $\mathrm{pH}$ è essencialmente assegurado pelos bicarbonatos dissolvidos e sua concentração deve ser pelo menos igual ou maior que $1.500 \mathrm{mg} / 1$ para garantir os níveis necessārios de biodigestão (KUBIAK \& DUBUIS, 1985).

A composição química da matēria orgânica afe- ta grandemente a biodigestão. De uma maneira geral, o mate- 
rial orgānico a ser degradado são carboidratos, iipídeos e proteinas. Existem certos grupos de componentes que se encontram inacessiveis ao complexo enzimātico das bactérias (celulose impregnada de lignina como nas madeiras, proteinas dos cabelos); tornando-os assim um substrato pouco biodigradável. Outra forma de se analisar este parâmetro é a necessidade nutricional de cada bactēria; Por exemplo, as bactērias acidogēnicas tem uma grande flexibilidade quanto a utilização de nutrientes, podendo assim, metabolizar uma gama vasta de materiais; jā as bactērias metanogênicas necessitam de poucos nutrientes para o seu crescimento (COSTA, 1986).

As condições de funcionamento estabelecidas (tipo de processo escolnido, temperatura etc.) afeta diretamente as populaçöes microbianas e obviamente reflete na produção de metano. (PERES, 1982). Estes parâmetros estão diretamente relacionados com o tempo de retenção hidräulica (TR) que é o parämetro normalmente utilizado para expressar a velocidade do processo, onde este é definido como volume do digestor/vazão do resíduo. Há exemplos de processos de digestão anaerōbica operando com TR desde algumas dezenas de dias até algumas poucas horas. Por exemplo, para um resíduo que contiver lg de matēria orgânicall o outro $10 \mathrm{~g} / 1$, a digestão anaeröbica do residuo mais concentrado deve ocorrer com uma velocidade 10 vezes maior, em relação 
a digestão anaeróbica do resíduo menos concentrado sob o mesmo TR, isto para obter-se igual eficiência (souzA, 1982a).

SILVA (1977), mostra valores indicativos de uma digestão para lodo de esgoto:

- pH nunca menor que 7,2;

- Biogás com teor de metano acima de $65 \%$;

- Biogās com teor de $\mathrm{CO}_{2}$ mäximo de $30 \%$;

- temperatura entre 28 a $35^{\circ} \mathrm{C}$ (faixa mesofilica);

- ácidos voláteis abaixo de $500 \mathrm{mg} / 1$. Um sūbito aumento de 200 a $300 \mathrm{mg} / 1$ no teor normal, indica sinal de perigo, tendo como solução reduzir a alimentação;

- alcalinidade total maior que $1.500 \mathrm{mg} / 1 \mathrm{co-}$ mo $\mathrm{CaCO}_{3}$

- não deve haver excesso de espumas no topo do nivel liquido.

2.4. Tipos de Biodigestores

Os biodigestores podem assumir diversas formas construtivas e a escolha dentre os diferentes tipos de- 
pende da aplicação especifica a que se destina, dos substratos empregados e dos recursos disponiveis para sua implantação (BARBOSA, 1982).

os biodigestores de uso mais generalizado (modelo Indiano e Chinês), possuem eficiência relativamente baixa, e têm como vantagem a utilização em meios rurais em pequenas propriedades, gerando soluções a curto prazo para os problemas de energia (COSTA, 1986).

\subsubsection{Concepção convencional}

A digestão anaeróbica pelo processo convencional, consiste em um tanque fechado, com ou sem agitação, podendo ou não ter um sistema de aquecimento ou apenas um isolante térmico. Este processo exige grandes volumes de biodigestão porque utilizam tempos de retenção bastante grandes (12 a 60 dias).

Na Figura 2 é mostrado o esquema de biodigestores convencionais.

Estes biodigestöres são empregados em resíduos semi-sólidos devido ao seu elevado conteúdo de sólidos em suspensão como é o caso do lodo de esgoto e resíduos agrícolas (souza, 1982b, Craveiro, 1980). 


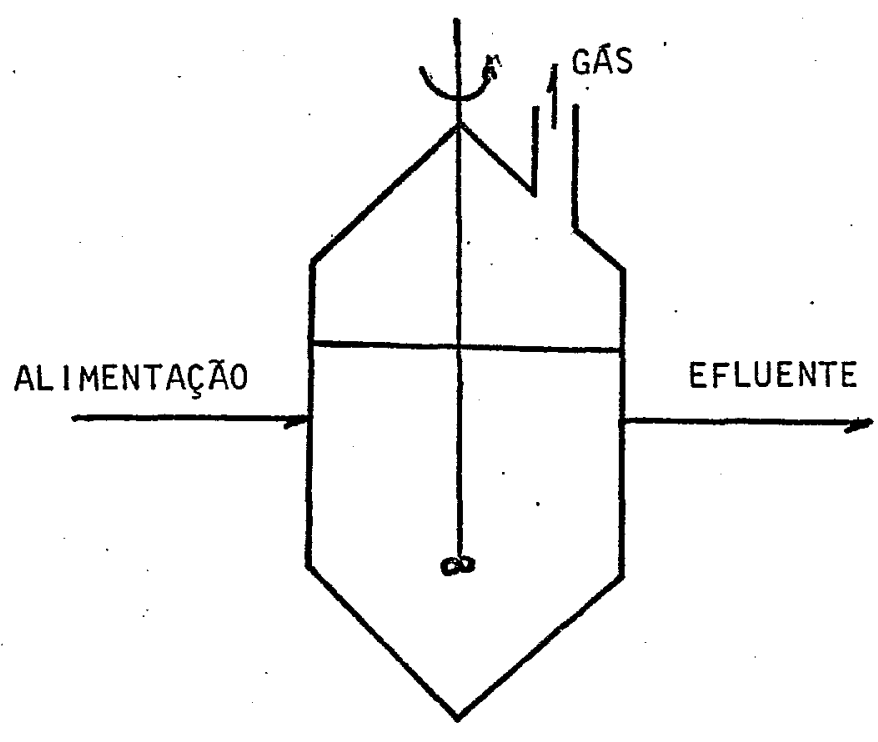

Figura 2: Esquema do biodigestor convencional

2.4.2. Concepção não-convencional

Utilizados em tratamentos de resíduos líquidos industriais onde o conteüdo de sólidos em suspensão é bem menor.

Os biodigestores não-convencionais operam em tempos de retenção bem baixo ( 5 a 50 horas), com isso os volumes dos biodigestores são bastante reduzidos. O princípio bä́sico desses biodigestores consiste em reter no sistema parte do lodo formado e assim as bactérias responsäveis pelo processo, impedindo sua eliminação com o efluente (SOUZA, 1982 b). 


\subsubsection{Filtros anaeröbicos}

São biodigestores constituídos de um leito com material de enchimento adequado (pedras, anéis de Rasching, feixe de tubos etc.), o qual fica completamente imerso no líquido. 0 residuo a ser tratado é alimentado geralmente pela extremidade:inferior do filtro e é descartado pela extremidade superior. (COSTA, 1986).

Parte do lodo adere-se ao material de enchimento e parte fica retida nos intersticios de enchimento; assim, o material de enchimento atua como uma barreira física para evitar que o lodo deixe o sistema (Figura 3 ).

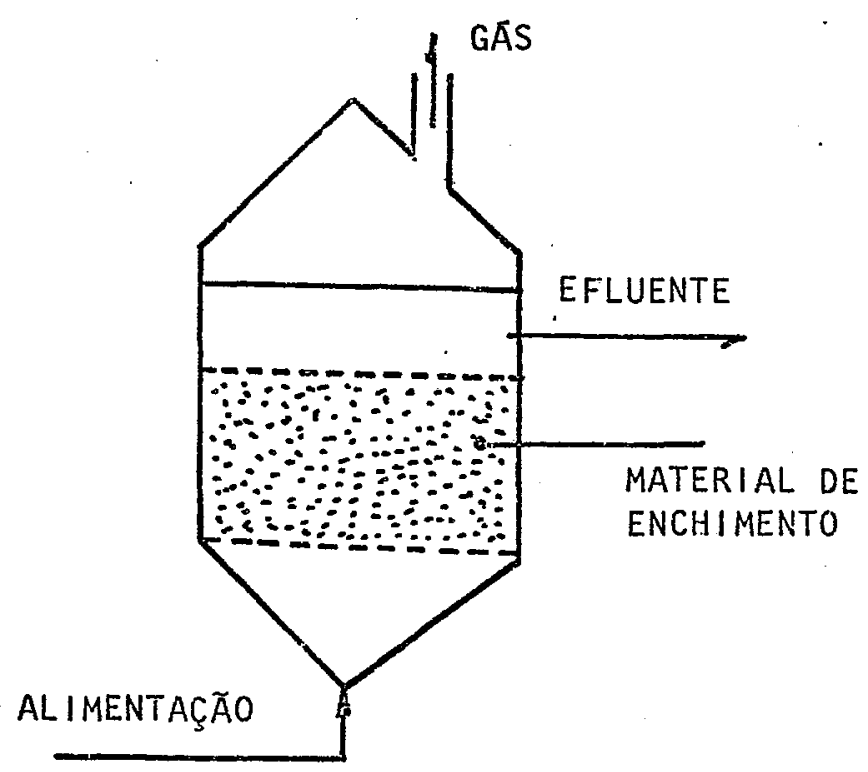

Figura 3: Filtro anaeróbico 


\subsubsection{Biodigestores de contato}

São biodigestores providos de sistema de agitação interna alèm de decantação externa do efluente, permitindo que o lodo decantado, ou parte dele, retorne ao reator num mecanismo de reinoculação contínua ou intermitente (Figura 4) (COSTA, 1986).

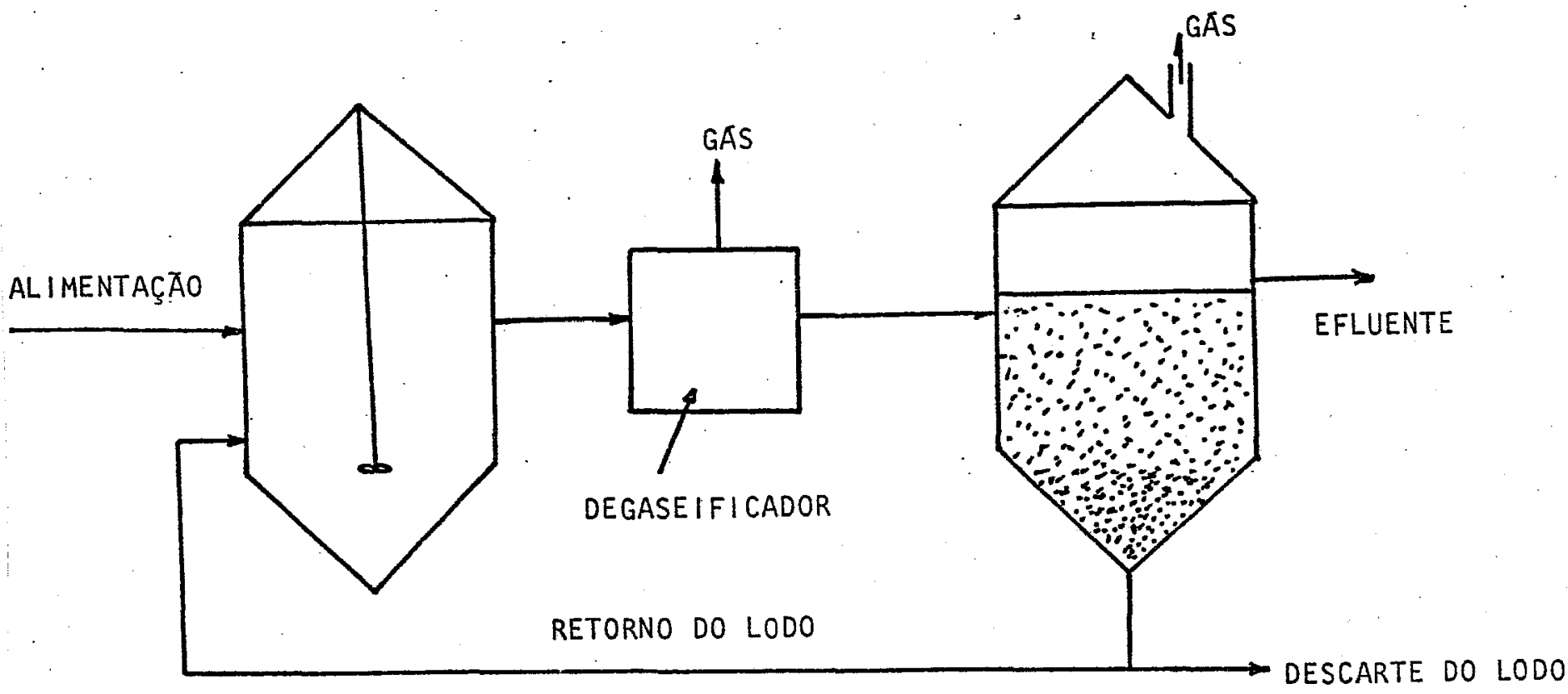

Figura 4: Esquema do biodigestor de contacto

2.4.2.3. Biodigestor de fluxo ascendente

São biodigestores de reciclo gravitacional 
contínuo de lodo, o qual efetua a concentração da biomassa ativa sem necessidade de intervenção de partes mecânicas, de modo que não hã destruição dos aglomerados de lodos formados. Desta forma, apenas as particulas de lodo mais leves deixam o biodigestor, permanecendo ao longo do tempo, uma elevada e ativa população microbiana. Na Figura 5 é esquematizado um biodigestor modelo. Fluxo ascendente. (COSTA, 1986).

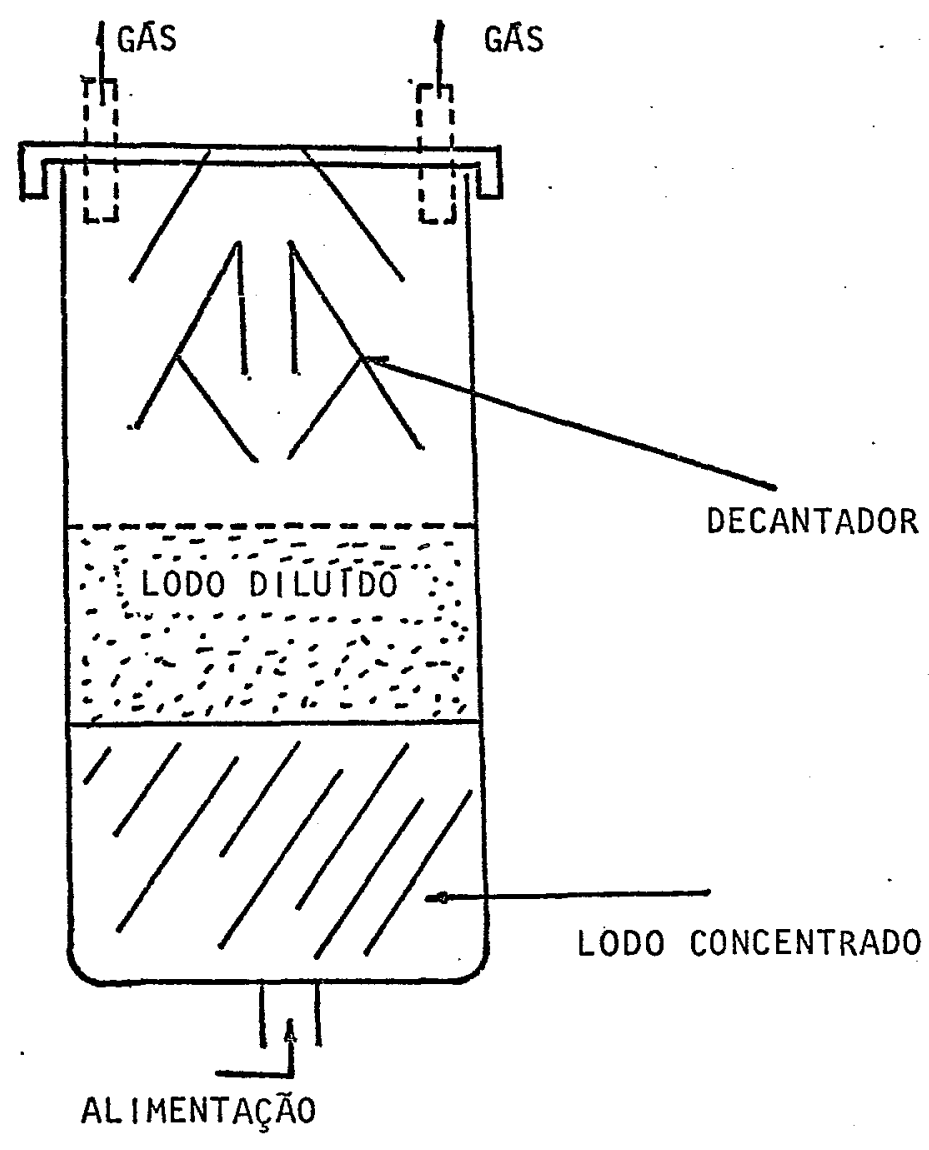

Figura 5: Biodigestor tipo Fluxo ascendente. 
2.5. Digestão Anaerōbica do Soro de Queijo

A digestão anaeróbica tem sido empregada em tratamentos de residuos semi-sölidos (lodos de esgoto, lixo doméstico e. estrume) e nesses casos os biodigestores utilizados são tanques sem recirculação do lodo e os tempos de retenção variam de 15 a 60 dias. Quando os despejos são 1 íquidos, os biodigestores contém-um sistema de recirculação de inöculo (lodo biolögico) e consequentemente os tempos de retenção para esses 1 íquidos podem ser reduzidos para 2 a 5 dias (VIEIRA \& SOUZA, 1981).

SOUZA (1982b) demonstra que os processos anaeróbicos vêm tornando-se uma alternativa nobre para o tratamento direto de efluentes líquidos industriais e cita tambēm que industrias como os laticinios onde geram efluentes com elevada carga orgânica, poderiam aplicar a biodigestão yisando tratamento de resíduo e produção de biogās.

Cerca de $40 \%$ do soro produzido não vem sendo aproveitado mas sim descarregados em rios ou cörregos. Devido ao seu elevado conteūdo de matéria orgânica (DBO $=40.000$ $\mathrm{mg} / \mathrm{L})$ faz com que este se torne um dos mais potentes residuos das Indústrias de Alimentos (Cerca de $10 \overline{\mathrm{kg}}$ de soro 1 íquido equivale ao resíduo disponivel de 45 pessoas) 1986 
Basicamente, as características de um determinado resíduo industrial que devem ser consideradas para se prever a viabilidade tēcnica e econōmica de seu tratamento por digestão anaeróbica são as seguintes: grau de biodegradabilidade, concentração de nutrientes (Nitrogênio e Fösforo), pH e concentração de compostos töxicos (souzA, 1982a).

Em relação ao grau de biodegradabilidade, um resíduo pode ser considerado biodegradāvel quando suas demandas químicas e biolōgicas de oxigênio obedecerem a relação $D Q O / D B O=2$ a 3 ; No caso do soro de queijo a relação se encontra na faixa de $2-3$, com isso evidentemente mais fácil e eficiente será seu tratamento por processos biológicos $\left(D B O=30\right.$ a $40 \mathrm{~g} D B O_{5} / 1$ de soro, $D Q O=60$ a $80 \mathrm{~g} \mathrm{DQO} / 1$ de soro) (BYLUND, 1975; SOUZA, 1982a).

Para que a digestão anaeróbica de um resíduo ocorra com uma boa performance, este residuo deve conter concentrações adequadas de nitrogênio e fósfono disponiveis. Certos resíduos necessitam de correções ou controles desses nutrientes. No caso do soro de queijo, a composição química deste 1\% de (proteínas e presença da maioria dos sais minerais) è suficiente para tornar o processo viável (LO \& LIAO, 1982a e b; VIEIRA E SOUZA, 1981).

Certos residuos, com pH bem baixo permitem a utilização deste sistema devido à capacidade de tamponamen- 
to sem que haja necessidade de adição de älcalis; o soro dependendo da manufatura e o tipo de queijo pode ter ou não $\mathrm{pH}$ ácido. No caso do queijo tipo cottage, o soro obtido tem $\mathrm{pH}$ àcido $(4,7)$ jā no quéijo tipo cheddar, o soro obtido tem pH próximo a neutralidade $(6,1)$. Nos resíduos com pH ácidos há necessidade de correções para manter o controle do pH na faixa ötima do funcionamento do biodigestor ( 1986; ARAÚJo et ali i, 1986).

A digestão anaeróbica do soro de queijo vem sendo estudada por inümeros pesquisadores e a eficiência deste tratamento ē grandemente afetada pelo tipo de resíduo e biodigestor.

ARAUJO et alii (1986) utilizaram dois biodigestores em escala de bancada para a produção de biogās a partir de soro de queijo utilizando tempo de retenção hidráulica de 20 a 30 dias, onde a temperatura foi mantida à $36^{\circ} \mathrm{C}$. Nesse experimento, conseguiram atingir a produção de 1,1 litros de biogàs por grama de sölidos volàteis adicionados; a carga máxima aplicada foi de 1,8 grama de sólido voläteis por litro de biodigestor.

COSTA \& LACAVA (1986) estudaram observações preliminares da digestão anaeröbica do soro de queijo tipo frescal sob diversas condições de cultura. Processaram a digestão do soro à pequenos volumes $(50 \mathrm{ml})$ em frascos de 
$225 \mathrm{ml}$, inoculados com mais de $5 \%$ de esterco bovino digerido, estando estes frascos sob atmosfera de $\mathrm{N}_{2}$ e submetidos a diferentes condições resultantes da combinação dos parámetros $\mathrm{pH}$ e temperatura. As melhores condições de digestão observadas foram a temperatura de $37^{\circ} \mathrm{C}$, principalmente com $\mathrm{pH} 6,2$ nas concentraçōes de $10 \%$ e $50 \%$ do soro.

LO \& LIAO (1986 a e b) utilizaram um biodigestor em escala laboratorial rotatório de contato para produção de biogás a partir de soro de queijo. Foi estudada a digestão continua de soro à temperatura mesofilica $\left(35^{\circ} \mathrm{C}\right)$ e tempos de retenção de 11 a 5 dias. A produção de metano alcançada foi de 1,68 a $3,261 \mathrm{CH}_{4} 1$ biogás ${ }^{-1} \cdot$ dia $^{-1}$, com uma remoção de 76 a $93 \%$ da DQ0. Como o soro possui elevado teor orgânico, houve necessidade de fazer diluição quando foi utilizado $T R=5$ dias. Um sistema de biodigestäo de dois estägios uti lizando biodigestores de contato foi tambēm estudado, os resultados alcançaram uma eficiência de $89,5 \%$ de remoção de DQO.

HARISCHANDRA \& SAVENA (1969), utilizando biodigestores com sistema de agitação conseguiram reduzir $83 \%$ de DBO com uma carga de $2,92 \mathrm{~kg} D B O \mathrm{~m}^{3^{-1}} \cdot \mathrm{dia}^{-1}$.

FOLLMANN \& MARKL (1979a) conseguiram reduzir $98 \%$ de DQO do efluente centrifugado com uma carga adicionada nos biodigestores de $5,6{\mathrm{~kg} \mathrm{DQO} \mathrm{m}^{-1}}^{-1} \mathrm{dia}^{-1}$ mesmos 
autores estudando em escala laboratorial a digestão anaeróbica do soro, conseguiram produzir 36,81 de biogás/l de soro. Neste trabalho foram necessärios 35 dias para a estabilização e o pH controlado ao redor de 7,0 com um tempo de retenção de 12,5 dias.

Holder \& Sewards, citado por BARFORD et alii (1986), utilizaram um biodigestor de contato em escala laboratorial para estudar a digestão anaeróbica de soro de queijo; a redução de DQO conseguida foi de aproximadamente $90 \%$ utilizando uma alimentação de $4,0 \mathrm{~kg} D Q 0 / \mathrm{m}^{3}{ }^{-1}$. dia.

Parker, citadoipor BARFORD et alii (1986) utilizando tratamento similar de HOLDER \& SEWARDS, conseguiu obter uma boa eficiencia no tratamento do soro de queijo utilizando uma carga de $6,0 \mathrm{~kg} \mathrm{~m}^{3}{ }^{-1} \cdot \mathrm{dia}^{-1}$.

HICKEY \& OWENS (1980) utilizando biodigestores de leito fluidizado para estudar a digestão do soro, conseguiram reduzir $83,6 \%$ de DQO utilizando $13,4 \mathrm{~kg} \mathrm{DQO} \mathrm{m}^{3^{-1}}$.dia ${ }^{-1}$ num tempo de retenção de 1,4 dia.

BARFORD et alii (1986), estudaram a digestão anaeróbica de soro de queijo em escala laboratorial utilizando uma carga máxima de $16,1 \mathrm{~kg}$ DQO $\mathrm{m}^{3^{-1}} \cdot$ dia $^{-1}$; foi obtido uma remoção de DQO de aproximadamente $99 \%$; neste mesmo trabalho os autores avaliaram a eficiência da adição de floculantes quimicos com a finalidade de elevar a quantidade de biomassa 
nos biodigestores e conseguiram um aumento desta em relação à um biodigestor controle.

SUTTOW E LI (1981) alimentando um biodigestor de leito fluidizado com uma carga de soro de $5,3-7,4 \mathrm{~kg}$ $D Q O / m^{3}$.dia conseguiram remover aproximadamente $82 \%$ de DQO. Switzen Baum E Dankin, citado por BARFORD et alii (1986), utilizaram um biodigestor de leito fluidizado no tratamento de soro de queijo, neste trabalho a remoção de DQO foi de aproximadamente $92 \%$ com uma carga adicionada ao biodigestor de 8,2 $\mathrm{kg} \mathrm{DQO} / \mathrm{m}^{3} \cdot \mathrm{dia}$.

BOENING \& LARSEN (1982) estudaram o tratamento do soro obtido da fabricação de caseína na digestão anaerōbica utilizando biodigestores de leito fluidizado. A eficiência alcançada foi de aproximadamente $90 \%$ de remoção de DQO adicionando uma carga de $7,7 \mathrm{~kg} \mathrm{DQO} / \mathrm{m}^{3} . \mathrm{dia}$ e $70 \%$ de remoção de $D Q O$ adicionando $19,5 \mathrm{~kg} \mathrm{DQO} / \mathrm{m}^{3} . \mathrm{dia}$, ambos tratados a $35^{\circ} \mathrm{C}$. Neste trabalho foi mostrado que a eficiência da remoção do material orgânico diminui com o aumento da carga de DQO de alimentação. Outro exemplo deste acontecimento ë citado por BARFORD et ali $\mathrm{i}(1986)$ onde adicionaram $37,6 \mathrm{~kg}$ $D Q 0 / m^{3}$.dia ao biodigestor e um $T R=4,9$ dias; conseguiram remover somente $72 \%$ DQO.

Assim, o tratamento de residuos das Indūstrias de Laticínios pela digestão anaeröbica vem mostrando ser 
eficiente remoção da DQO do material orgânico; futuramente estudos destes tratamentos devem tentar diminuir o tempo de retenção do resíduo sem afetar a eficiência do tratamento. 


\title{
3. MATERIAIS E METODOS
}

\author{
3.1. Materiais
}

3.1.1. Biodigestores

Foram utilizados seis biodigestores semicontínuos de material PVC (capacidade $=2$ litros) como mostra a Figura 6 .

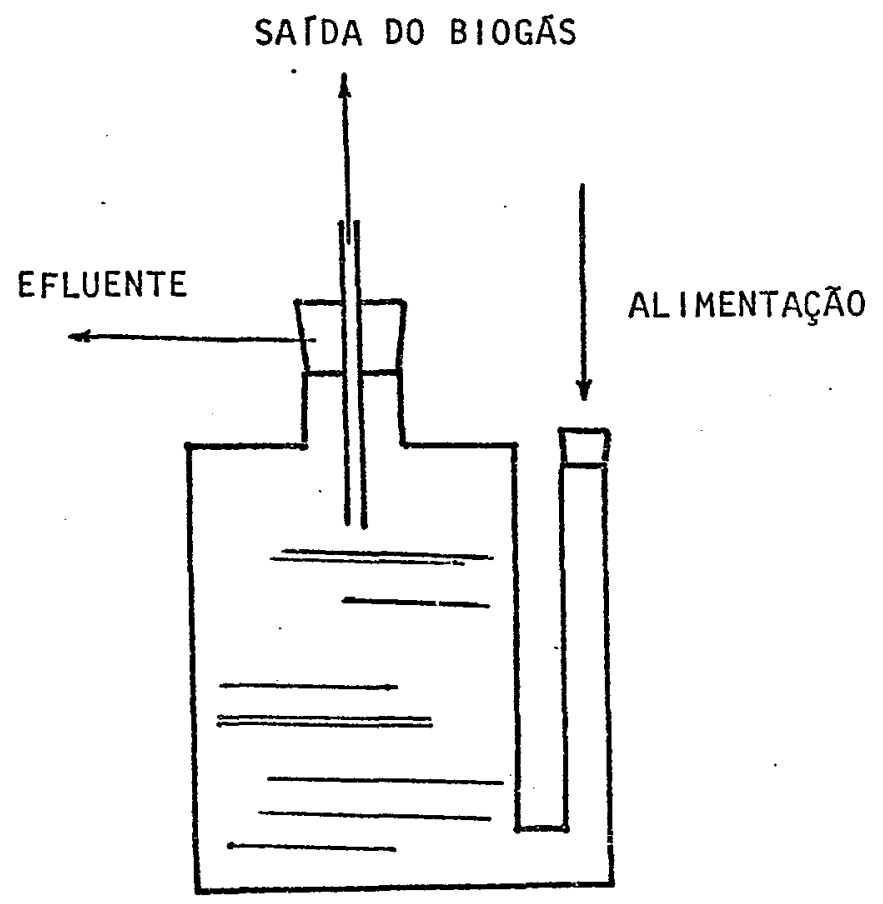

Figura 6: Esquema do biodigestor utilizado. 
3.1.2. Inöculo

Cada biodigestor foi inoculado com 1,6 l de uma flora mista (esterco bovino) coletada de um biodigestor em funcionamento cedido pela BRASMETANo Tecnologias Integradas - Piracicaba (SP). o inōculo foi previamente diluído a aproximadamente $8 \%$ de sólidos totais (ST).

\subsubsection{Substrato}

A alimentação dos biodigestores foi efetuada com soro de queijo obtido da fabricação de queijo tipo Minas Frescal na Escola Superior de Agricultura "Luiz de Queiroz". $\mathrm{Na}$ Tabela 4 são mostrados os: resultados das anälises físico-químicas do soro de queijo utilizado no experimento.

$\begin{aligned} & \text { Tabela 4: Características físico-químicas do soro de } \\ & \text { queijo utilizado }\end{aligned}$
$\begin{array}{lr}\text { Parámetro } & 4,5-4,6 \\ \text { PH } & 67.000-68.000 \mathrm{mg} \mathrm{DQ0} / 1 \text { soro } \\ \text { DQO } & 5,43 \% \\ \text { ST } & 50,94 \% \\ \text { SV }\end{array}$

0 armazenamento do soro de queijo para subsequente utilização foi realizado sob refrigeração à tempera- 
tura de $2^{\circ} \pm 1,0^{\circ} \mathrm{C}$.

\subsection{Mëtodos}

\subsubsection{Condições gerais do experimento}

Para os ensaios foram utilizados 6 biodigestores, com um volume de inóculo igual a 1,61 , mantidos em banho-maria à $35^{\circ} \mathrm{C} \pm 0,5$. A operação foi realizada em regime semicontínuo, com alimentação diāria dos biodigestores (sendo a carga orgânica de $5,38 \mathrm{~g}$ DQO/dia). Os biodigestores, contendo o material em digestão, eram agitados manualmente após cada alimentação e estavam acoplados a um gasômetro de deslocamento de líquidos. Na Figura 7 é esquematizado o sistema operacional do experimento.

o pH do soro de queijo utilizado na alimentação dos biodigestores foram corrigidos com bicarbonato de sódio diariamente como mostram os tratamentos da Tabela 5; nesta Tabela é mostrado também a carga de DQO do soro de alimentação.

Tabela 5: Tratamentos utilizados no ensaio

\begin{tabular}{|c|c|c|c|}
\hline Tratamento & Biodigestores & $\mathrm{pH}$ do soro de quei jo & carga adicionada \\
\hline 1 & 1 e 2 & 4,5 (normal) & 5,38 \\
\hline 2 & 3 e 4 & 5,5 & 5,38 \\
\hline 3 & 5 e 6 & 6,5 & 5,38 \\
\hline
\end{tabular}




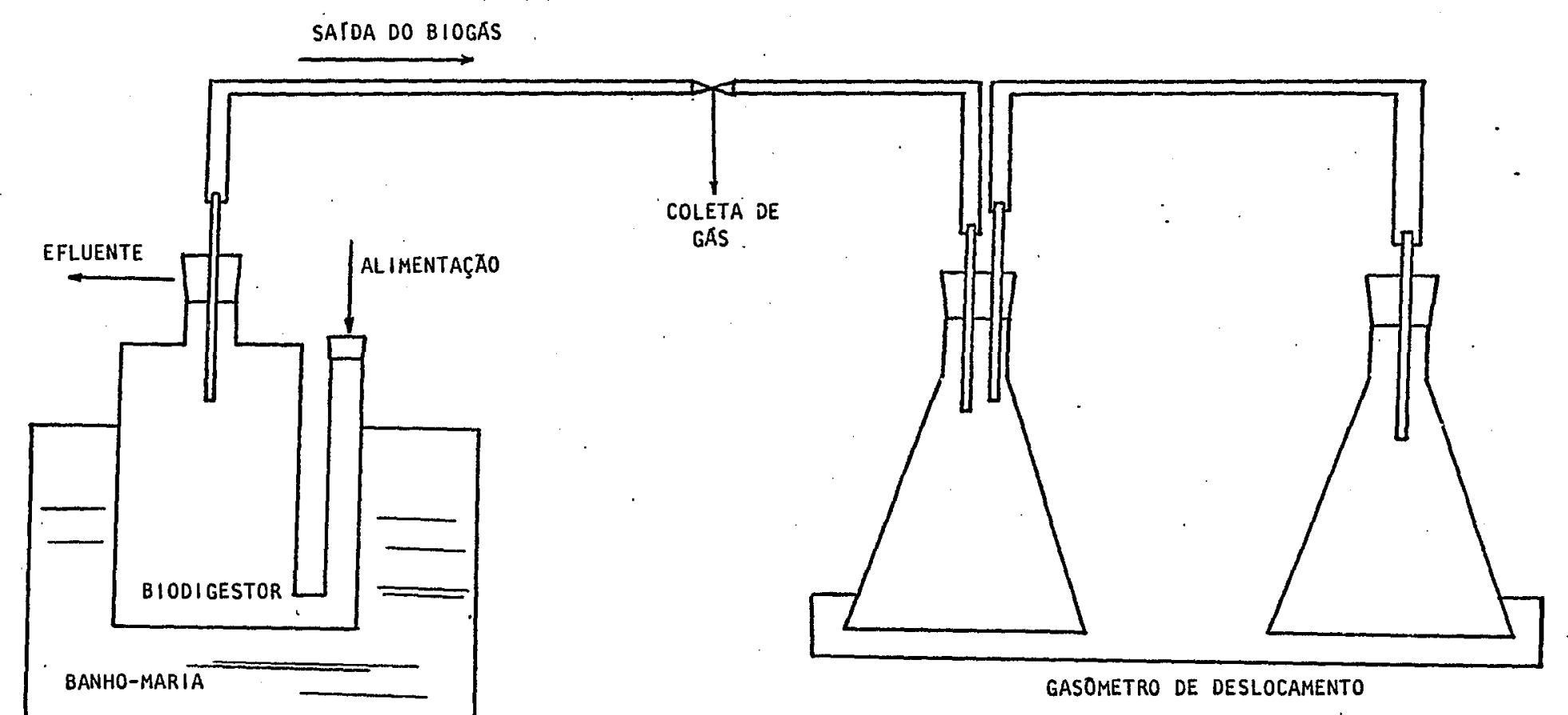

Figura 7: Esquema do sistema utilizado no experimento. 


\subsubsection{Condução do experimento}

A digestão anaeröbica do soro de quejo

foi conduzida num período de 100 dias, dividido em 2 estágios.

\subsubsection{Aclimata:ção do inōculo}

A aclimatação do inóculo corresponde a uma fase ou período em que deve haver uma adaptação da flora microbiana ao novo substrato empregado. Paratal, os biodigestores foram alimentados com uma carga orgânica correspondente a $1,3 \mathrm{~g}$ DQO/dia em relação a carga final prevista $(5,38 \mathrm{~g} \mathrm{DQO} / \mathrm{dia})$, com um aumento gradual desta em relação à eficiência da remoção da carga orgânica, a fim de permitir uma adaptação do inōculo ao soro de queijo. No presente trabalho, foram necessärios 20 dias para aclimatação do inöculo.

3.2.2.2. Operação normal dos biodigestores

Apōs atingir a aclimat ação do inōculo, os biodigestores foram alimentados diariamente com $5,38 \mathrm{~g}$. DQO ( $80 \mathrm{ml}$ de soro de queijo), de modo que o tempo de retenção (TR) do sistema foi fixado então em 20 dias.

Na Tabela 6 são apresentados os quatro tempos 
de retenção com os respectivos sistemas de alimentação utilizados no experimento.

Tabela 6: Sistemas de alimentação utilizados em cada TR.

\begin{tabular}{c|c|c|c|}
\hline $\begin{array}{c}\text { Tempo de } \\
\text { retenção }\end{array}$ & $\begin{array}{c}\text { Carga diária } \\
\text { adicionada }\end{array}$ & $\begin{array}{c}\text { Parcelamento do volume de } \\
\text { soro adicionado durante } \\
\text { o dia }\end{array}$ & $\begin{array}{l}\text { Intervalo de } \\
\text { tempo (h) para } \\
\text { a adição do soro }\end{array}$ \\
\hline
\end{tabular}

TR

g DQO

19

$(10-200$ dia $) \quad 5,38$

29

$(219-40$ e dia)

5,38

$40: 40$

12

39

$(419-609$ dia $)$

5,38

$20: 20: 20: 20$

6

49

$(619-809$ dia)

5,38

80

24

A cada alimentação efetuada foi retirado simultaneamente pelo topo amostras do efluente, para avaliar o tratamento.

3.2.3. Parâmetros para acompanhar e avaliar o processo da digestão anaeróbica 


$$
3 \cdot 2 \cdot 3 \cdot 1 \cdot \mathrm{pH}
$$

Esta medida foi realizada diariamente, no substrato e efluente, utilizando o medidor de $\mathrm{pH}$ modelo DMPH-2/ /Digimed calibrado com solução tampão 7,0 e 4,0.

Para a determinação do $\mathrm{pH}$, uma amostra do efluente de cada biodigestor foi coletada e logo após feito a leitura para evitar alterações desta medida com a perda de $\mathrm{CO}_{2}$. Foi considerado o valor minimo observado (VIEIRA \& SOUZA, 1981.).

\subsubsection{Volume de gases produzidos}

A produção de gás foi monitorada diariamente utilizando-se para essa medida um gasômetro de deslocamento de líquido com uma solução salina acidulada (solução de $\mathrm{Na}_{2} \mathrm{SO}_{4}, 25 \%$ e $\mathrm{H}_{2} \mathrm{SO}_{4}, 5 \%$ ) (STANDARD METHODS FOR EXAMINATION OF WATER AND WASTE WATER, 1976).

$3 \cdot 2 \cdot 3 \cdot 3$. Composição do gäs

A composição do gäs foi monitorada de 3 em 3 dias: A amostra foi retirada pelo coletor com uma seringa, atravēs de um tubo com septo de silicone (tubos new väcuo) e injetadas no cromatógrafo em fase gasosa (VIEIRA \& SOUZA, 1981), com coluna N Porapak. 
3.2.2.4. Äcidos voläteis

A determinação da quantidade de ácidos voláteis existentes no biodigestor foi efetuada segundo VIEIRA \& SOUZA (1981).

Ao efluente centrifugado foi adicionado $\mathrm{H}_{2} \mathrm{SO}_{4}$ $0,1 \mathrm{~N}$ pela titulação até $\mathrm{pH} 3,3$.

Para liberação do $\mathrm{CO}_{2}$; a amostra foi fervida. durante 3 minutos e resfriada em ägua fria.

Em seguida, o pH da amostra foi corrigido a $4,0 \mathrm{com} \mathrm{NaOH} 0,1 \mathrm{~N}$ e deste ponto foi continuada a titulação até $\mathrm{pH} 7,0$ e anotado 0 volume gasto de $\mathrm{NaOH} 0,1 \mathrm{~N}$ para correção do $\mathrm{pH}$ de 4,0 a 7,0 .

A concentração de ácidos voláteis, expressa em mg $\mathrm{CH}_{3} \mathrm{COOH} / 1$ foi calculada como mostra a fórmula a seguir:

$$
\text { Acidez }\left(\mathrm{mg} \mathrm{CH} \mathrm{CH}_{3} \mathrm{COOH} / \mathrm{l}\right)=\frac{\mathrm{ml} \mathrm{NaOH} \times \mathrm{N} \times 60.000}{\mathrm{ml} \text { da amostra }}
$$

\subsubsection{Alcalinidade}

A alcalinidade foi conduzida pela titulação da amostra centrifugada $\mathrm{Com} \mathrm{H}_{2} \mathrm{SO}_{4} 0,1 \mathrm{~N}$ atè $\mathrm{pH}$ 4, 0 , anotando-se - volume de solução gasta (VIEIRA \& SOUZA, 1981). 
A alcalinidade expressa eii mg $\mathrm{CaCO}_{3} / 1$ foi calculada como mostra a fórmula a seguir:

Alcal inidade total $\left(\mathrm{mg} \mathrm{CaCO}_{3} / \mathrm{L}\right)=\frac{\mathrm{ml} \mathrm{de} \mathrm{H}_{2} \mathrm{SO}_{4} \times \mathrm{N} \times 50.000}{\mathrm{ml} \mathrm{da} \mathrm{amostra}}$

3.2.2.6. Demanda química de oxigênio (DQO)

A DQO é o parâmetro que demonstra o conteúdo de matēria orgânica do resíduo a ser digerido e expressa a eficiência de remoção do material orgânico no efluente.

O mëtodo utilizado para determinar a DQO no substrato e efluente é o método segundo STANDARD METHODS FOR EXAMINATION OF WATER AND WASTE WATER, 1976.

Foi colocado cerca de $0,4 \mathrm{~g}$ de sulfato de mercürio em balão de $500 \mathrm{ml}$ de fundo chato juntamente com a amostra do efluente centrifugado e completado o volume a $20 \mathrm{ml}$ mais $10 \mathrm{ml}$ de solução de dicromato de potássio $0,25 \mathrm{~N}$.

Vagarosamente foram adicionados ao balão 30 ml da solução àcido sulfürico, sulfato de prata e adicionado algumas pérolas de vidro, em seguida conectado ao condensador de refluxo.

A amostra foi refluxada por um período de duas horas e em seguida foi colocada para resfriar e adicionado água destilada até cerca de $140 \mathrm{ml}$. 
0 mesmo procedimento foi utilizado para

prova em branco.

Apōs a adição de 3 gotas de indicador ferroin foram titulados a amostra e o branco com a solução de sulfato ferroso amoniacal com normalidade padronizada.

Para calcular a DQO do efluente centrifugado a fórmula utilizada foi a seguite:

$$
\frac{(a-b) \times c \times 8.000}{m 1 \text { da amostra }}=\mathrm{mg} / 1 \text { de DQO }
$$

onde:

$a=m l$ de sulfato ferroso amoniacal gastos com o branco

$b=m l$ de sulfato ferroso amoniacal gastos com a amostra

$c=$ normalidade da solução de sulfato ferroso amoniacal 


\title{
4. RESULTADOS E DISCUSSÕES
}

\author{
o principal objetivo deste trabalho consis- \\ tiu em avaliar em escala laboratorial a digestão anaeróbi- \\ ca do soro de queijo em biodigestores semicontinuos manti- \\ dos a faixa mesofilica de $35^{\circ} \mathrm{C} \pm 0,5$.
}

A digestão anaeröbica foi caracterizada por um estägio inicial que durou aproximadamente 20 dias a fim de conseguir a aclimatação do inōculo e quatro tempos de retenção compreendidos num período de 80 dias.

Para uma indicação imediata do funcionamento do processo foram utilizados três parâmetros, pH, alcalinidade e acidez volätil, os quais estão interligados e devem ser observados o seu comportamento em conjunto.

Foi determinado nos biodigestores a eficiência do tratamento anaerōbico em relação à remoção do material orgânico no efluente pela anälise de DQO, acompanhados da medição do volume de gases produzidos. 
4.1. Variação do $\mathrm{pH}$, Acidez Volátil e Alcalinidade da dígestão anaerōbica do soro de queijo com e sem correção de $\mathrm{pH}$

os resultados obtidos para $\mathrm{pH}$, alcalinidade expressa em mg $\mathrm{CaCO}_{3} / 1$ e acidez expressa em $\mathrm{mg} \mathrm{CH}_{3} \mathrm{COOH} / \mathrm{l}$ nos biodigestores $1,2,3,4,5$ e 6 encontram-se nas Tabelas 7 , 8 e 9 do Apêndice e nos Gräficos das Figuras $8,9,10,11$, 12 e 13

\subsubsection{Biodigestores alimentados com soro sem cor- reção de $\mathrm{pH}\left(\begin{array}{lll}1 & \text { e } & 2\end{array}\right)$}

0s biodigestores tratados com soro de queijo sem correção de $\mathrm{pH}$ e mantidos a $35^{\circ} \mathrm{C}\left(\begin{array}{lll}1 & \text { e } & 2\end{array}\right)$ iniciaram o 1 ? TR com uma acidez volätil de $500 \mathrm{mg} \mathrm{CH} \mathrm{CH}_{3} \mathrm{COH} / 1$. No final deste TR, onde a alimentação foi efetuada em intervalos de $8 \mathrm{~h}$ a acidez foi de $800 \mathrm{mg} / 1$. No 2 QTR com intervalo de alimentação de 12 h (carga de DQO dividida em duas vezes) a acidez começou a aumentar gradualmente, alcançando níveis no final deste intervalo: de $2.500 \mathrm{mg} / 1$. No $39 \mathrm{TR}$ com a carga total de $D Q O$ foi dividida em quatro vezes (intervalos de alimentação de $6 \mathrm{~h})$, a acidez continou a crescer e no final do 4 ? TR onde a carga de DQO diāria foi adicionada de uma só vez, a acidez alcançou niveis entre 6.500-6.900 mg $\mathrm{CH}_{3} \mathrm{COOH} / 1$. 


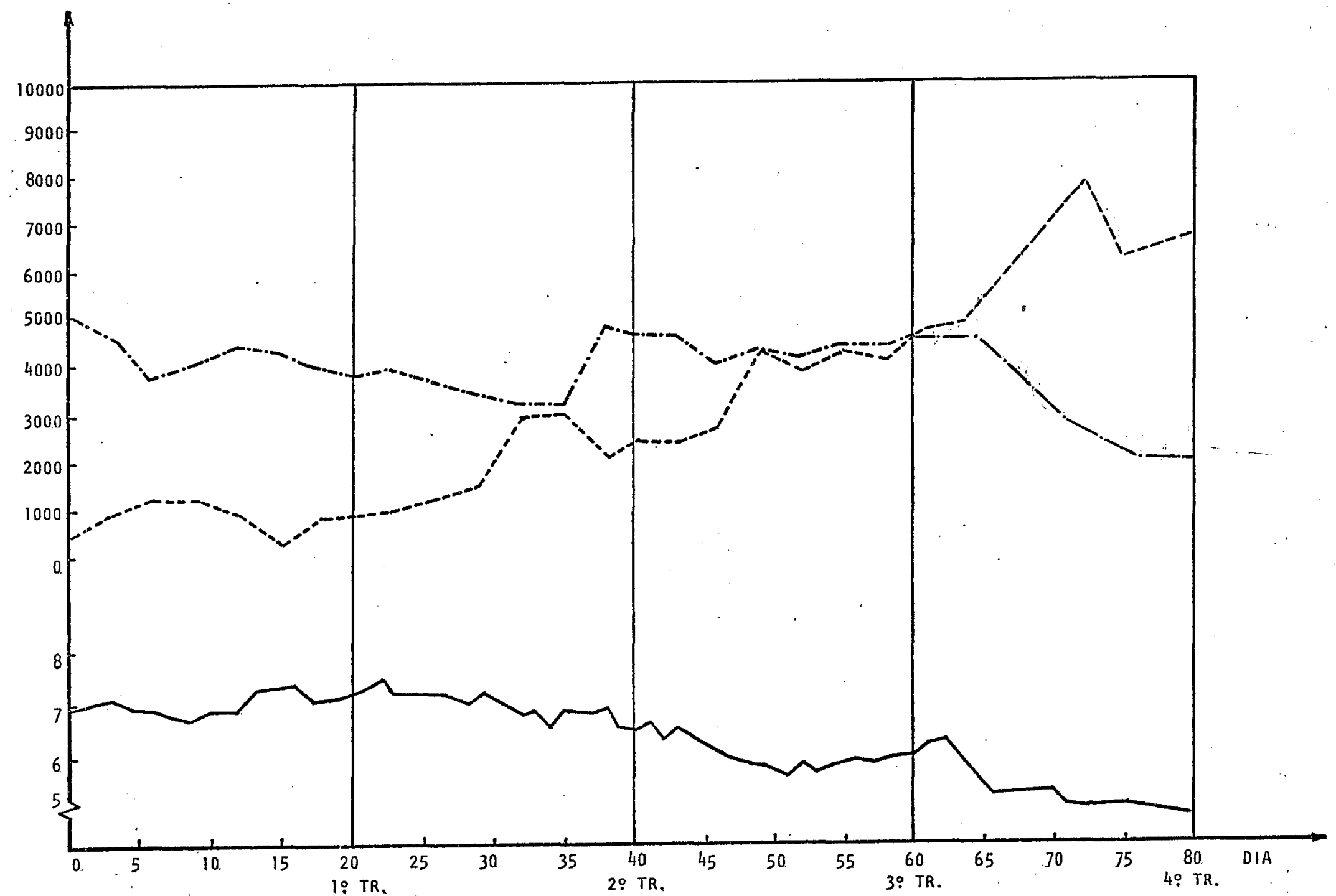

Figura 8: Valores de $\mathrm{pH}(-)$, acidez volätil expressa.em mg $\mathrm{CH}_{3} \mathrm{COOH} / 1$ (--) e alcalinidade expressa em $\mathrm{mg} \mathrm{CaCO} / 1$ (-...-) do biodigestor 1. 


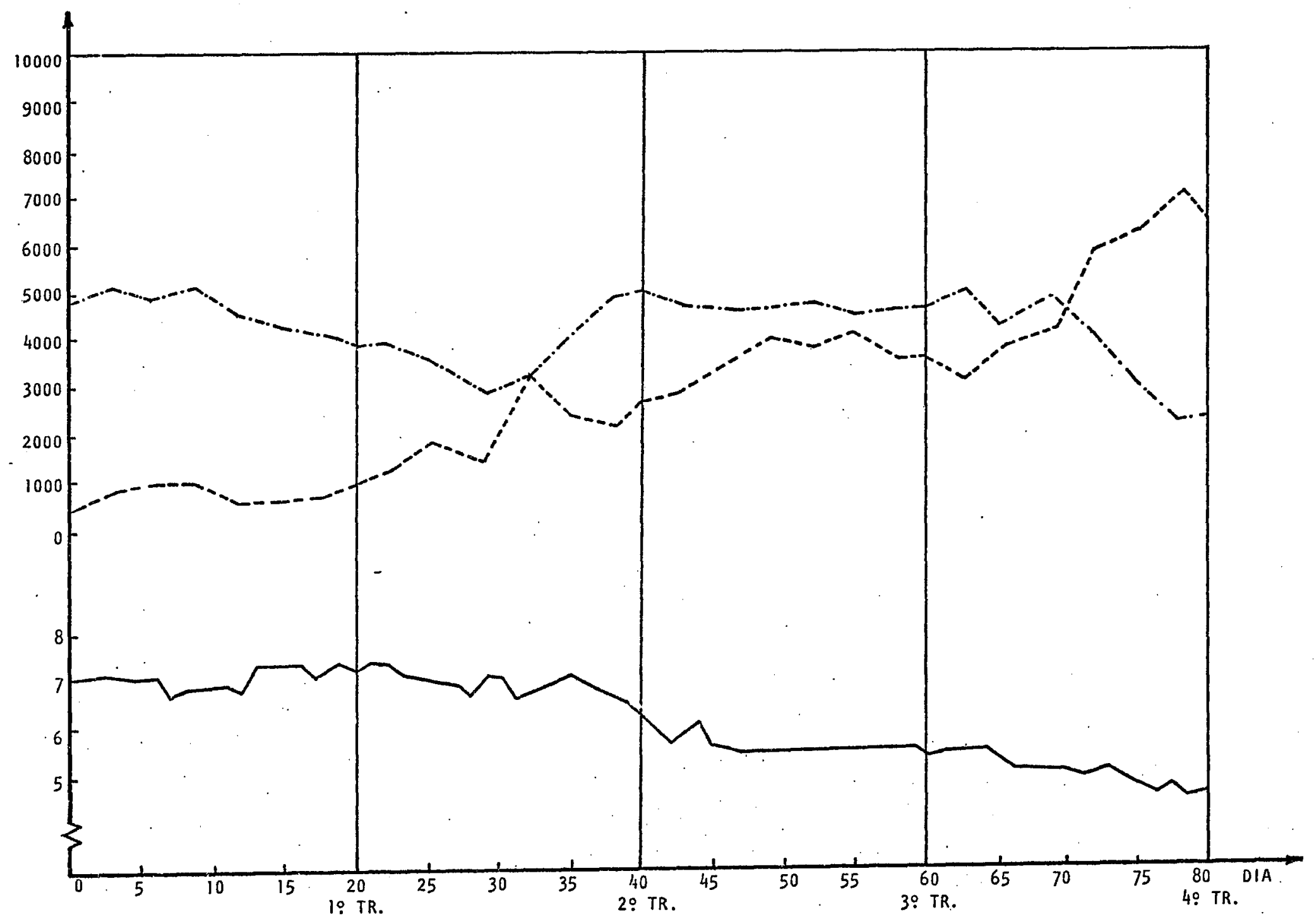

Figura 9: Valores de $\mathrm{pH}(-)$, acidez volátil expressa em $\mathrm{CH}_{3} \mathrm{COOH} / 1_{(---)}$e alcalinidade expressa em mg $\mathrm{CaCO}_{3} / 1(-. .-)$ do biodigestor 2 . 
De acordo com citação de SoUzA (1982a), nessas condições de acidez o processo não seria afetado desde que o pH não diminuisse, o que não ocorreu devido a produção de ácidos voláteis e possivelmente a alcanilidade do sistema não foi suficientemente elevada para evitar a queda do $\mathrm{pH}$ observado nesse tratamento.

No início do 39 TR $(409 \mathrm{dia})$ devido ao abaixamento do $\mathrm{pH}$, alēm das faixas ideais $6,8-7,2$ (McCARTY $\varepsilon$ MCKYNNEY, 1961) embora a acidez volätil (2.300-2.600 mg $\left.\mathrm{CH}_{3} \mathrm{COOH} / 1\right)$ não tivesse ainda atingido os limites de intolerância, esta tornou-se tōxica ao sistema, provocando a paralização completa da atividade microbiana nestes dois biodigestores, o que segundo McCARTY \& MCKYNNEY (1961) è devido ao acúmulo desses ácidos no meio, cujo efeito se faz sentir principalmente sobre as bactērias metanogènicas, uma vez que as bactērias acidogênicas de acordo com a citação de DE LA TORRE \& GOMA (1981) podem suportar atē $40.000 \mathrm{mg}$ de acidez volätil expressa em mg $\mathrm{CH}_{3} \mathrm{COOH} / \mathrm{l}$.

Por outro lado, a alcanilidade no 19TR inicialmente foi de 5.000 e $4.700 \mathrm{mg} \mathrm{CaCO} / 1(1 \mathrm{e} 2)$, e no final deste a alcanilidade decresceu acentuadamente. No 2 ? e 39TR a alcalinidade nos biodigestores oscilava entre 3.800$-4.500 \mathrm{mg} \mathrm{CaCO} / 1$, decrescendo bastante no 49TR, chegando no final deste a $2.300 \mathrm{mg} \mathrm{CaCO} / 1$. 
SOUZA (1982a) cita que um valor de alcalinidade de 2.500 a $5.000 \mathrm{mg} \mathrm{CaCO} / 1$ é desejável para o bom funcionamento da biodigestão, pois confere um poder de tamponamento ao meio em digestão. Entretanto, estes niveis podem variar com o substrato empregado. Por exemplo, VIEIRA $\varepsilon$ SOUZA (1981) citam que no caso do lodo primário, a faixa de alcalinidade ötima situa-se entre $2.500-4.000 \mathrm{mg} \mathrm{CaCO} / 1$, enquanto que para o restilo (resíduo da destilação do álcool) a alcalinidade deve variar entre 3.000 e $6.000 \mathrm{mg}$ $\mathrm{CaCO}_{3} / 1$. Já SILVA (1977) cita que a alcalinidade deve ser sempre superior à $1.500 \mathrm{mg} \mathrm{CaCO}_{3} / 1$.

Desta forma, nas condições do experimento sem correção do pH do soro de alimentação, ocorreu um aumento muito räpido da acidez volátil no 2 ọtR e a alcanilidade não foi suficiente para tamponar o meio nos próximos TR e criar boas condições para o desenvolvimento da biodigestão, o que vem de encontro como citado por SILVA (1977), que para um bom desempenho da digestão anaeróbica de esgoto, a acidez volätil deve se encontrar na faixa de $500 \mathrm{mg} \mathrm{CH} \mathrm{COOH}_{3}$, e um aumento de $300 \mathrm{mg} / 1$ no teor normal de acidez demonstra deficiència no tratamento.

4.1.2. Biodigestores alimentados com soro com pH corrigido a 5,5 ( 3 e 4$)$

Os biodigestores tratados com soro de queijo 
com pH corrigido a 5,5 com bicarbonato de sódio é mantidos a $35^{\circ} \mathrm{C}$, iniciaram o $19 \mathrm{TR}$ com uma concentração de àcidos voläteis semelhantes aos biodigestores 1 e $2(600$ e $360 \mathrm{mg} / 1)$ e no final deste TR a acidez oscilava entre 1.250-1.400 mg/ 11. A carga total de DQO neste TR foi dividida em trés parcelas, adicionadas em intervalos de 8 horas.

No início do 2oTR (alimentação de 12 em

horas) a acidez cresceu lentamente chegando alcançar níveis neste intervalo de 3.580 e $2.050 \mathrm{mg} / 1$. No 39 TR em que a carga total foi adicionada parceladamente de 6 em 6 horas, a acidez permaneceu semelhante ao $29 T R$ enquanto que no 49TR onde a carga total de DQO foi adicionada de uma só vez, a acidez oscilou entre $5.500-6.000 \mathrm{mg} \mathrm{CH}_{3} \mathrm{COOH} / 1$, como ocorrera no caso dos biodigestores 1 e 2 sem correção do $\mathrm{pH}$ inicial do soro, ocorrendo tambëm praticamente uma paralização da atividade microbiana causada pelo acúmulo de acidez no meio, como explicado anteriormente.

Em relação à alcalinidade, no lọR não houve grande modificação, onde esta alcançou níveis de $5.500 \mathrm{mg}$ $\mathrm{CaCO}_{3} / 1$ e, no final do $29 \mathrm{TR}$ a alcalinidade se elevou para 7.000 e $7.500 \mathrm{mg} \mathrm{CaCO} / 1$ (biodigestor 3 e 4 respectivamente), fazendo zom que a acidez do meio não afetassem o processo. No $39 T R$ a alcalinidade não oscilou e no início do 49TR esta decresceu lentamente, chegando ao final deste a uma concentração equivalente a inicial (5.700-5.400 $\left.\mathrm{mg} \mathrm{CaCO}_{3} / 1\right)$. 


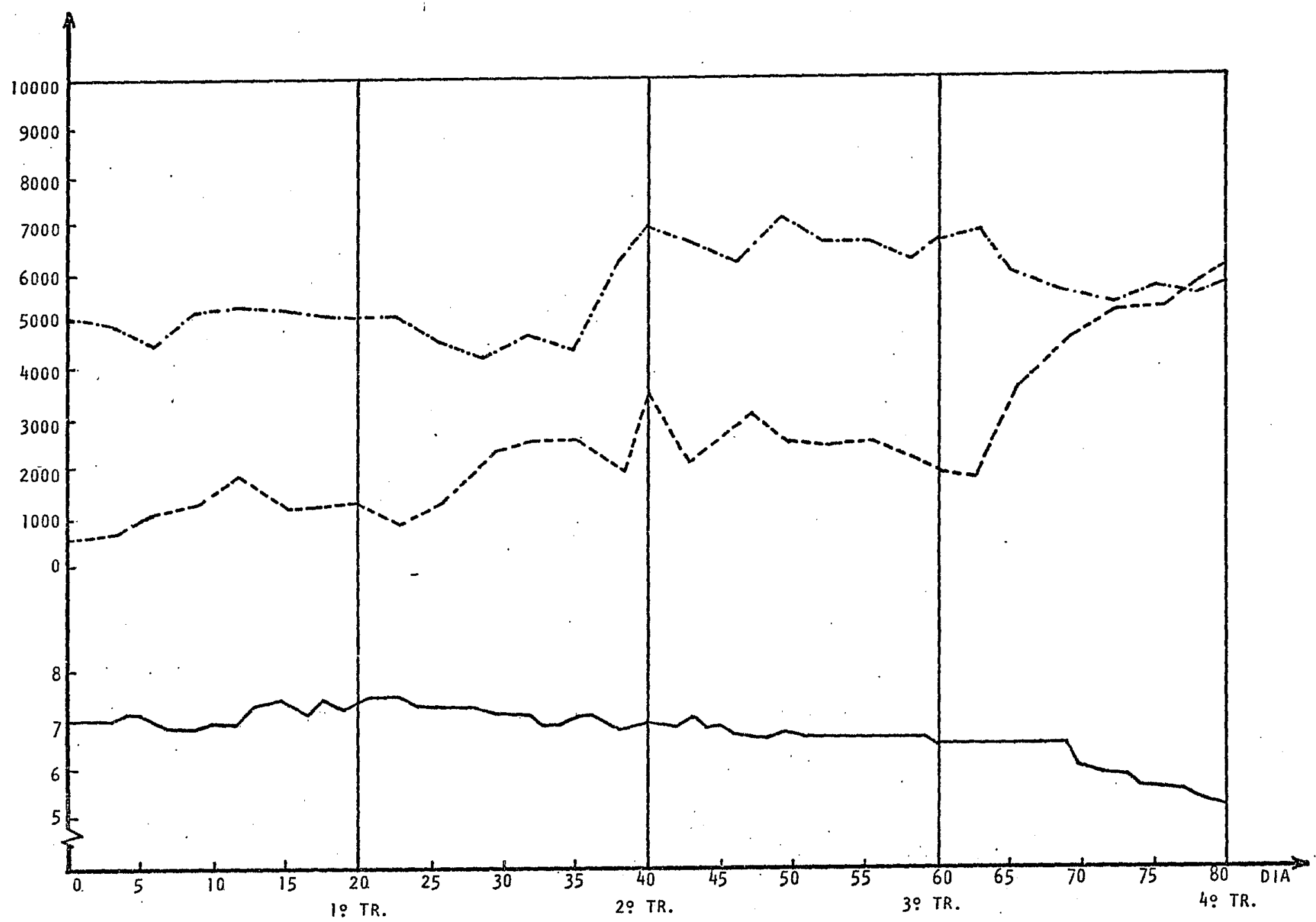

$\begin{aligned} \text { Figura 10: } & \text { Valores de } \mathrm{pH}(-) \text {, acidez volätil expressa em } \mathrm{mg} \mathrm{CH}_{3} \mathrm{COOH} / 1 \\ & \text { nidade expressa em } \mathrm{mg} \mathrm{CaCO} / 1(-\ldots .-) \text { do biodigestor } 3 .\end{aligned}$ 


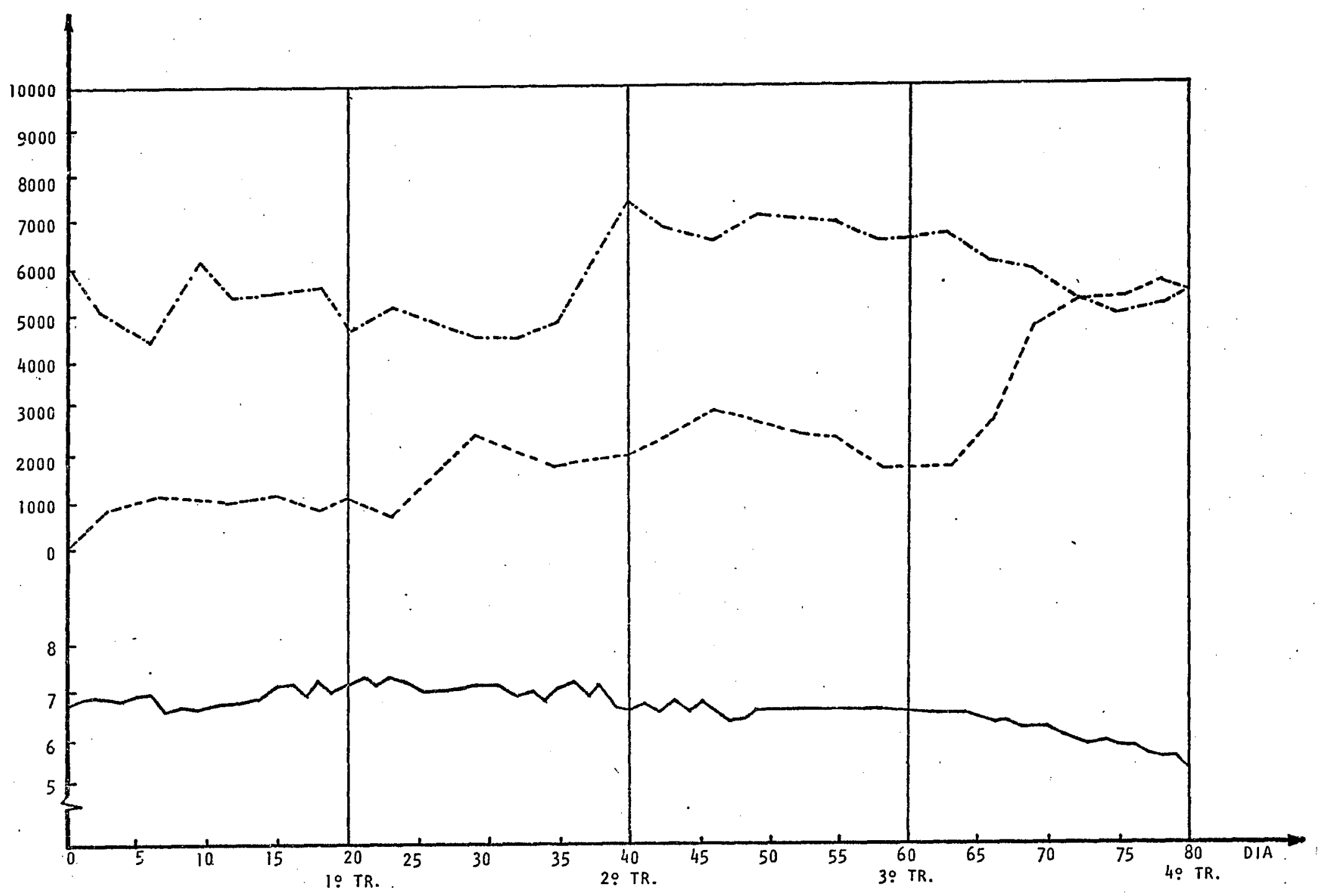

Figura 11: Valores de $\mathrm{pH}(-)$, acidez volätil expressa em mg $\mathrm{CH}_{3} \mathrm{COOH} / \mathrm{l}(--)$ e alcalinidade expressa em mg $\mathrm{CaCO}_{3} / 1(-.-$ - $)$ do biodigestor 4 . 
De acordo com a ci tação de SouzA (1982a) valores de alcanilidade para um bom funcionamento do processo se encontram entre 2.500 a $5.000 \mathrm{mg} \mathrm{CaCO} / 1$, o que ocorreu até o final do 39TR. Entretanto, no 49TR, a faixa de alcalinidade situava-se entre as faixas ideais, mas a acidez aumentou muito rápido com a alimentação adicionada de uma só vez juntamente com o declínio do pH.

Assim, no 40TR mesmo com a correção do pH do soro de queijo a 5,5, não foi conseguido o tamponamento do meio devido a acidez tornar-se tóxica quando a carga foi adicionada de uma só vez.

4.1.3. Biodigestores alimentados com soro com pH corrigido a 6,5 ( 5 e 6$)$

Os biodigestores tratados com soro de queijo com correção de pH a 6,5 com bicarbonato de sódio e mantidos a $35^{\circ} \mathrm{C}$, iniciaram o $19 \mathrm{TR}$ com uma acidez volätil semelhante aos tratamentos anteriores $\left(500\right.$ e $700 \mathrm{mg} \mathrm{CH}{ }_{3} \mathrm{COOH} / 1$ biodigestores 5 e 6 respectivamente) e no final deste tempo a acidez era de $2.000 \mathrm{mg} \mathrm{CH}_{3} \mathrm{COOH} / \mathrm{l}$. Neste intervalo (20 primeiros dias) a alimentação foi dividida em 3 partes (30-20-30) e adicionada em intervalos de 8 horas. $020 T R$, onde - intervalo de alimentação foi de 12 horas, a acidez alcançou niveis de 3.300 a $3.700 \mathrm{mg} \mathrm{CH} \mathrm{CH}_{3} \mathrm{COOH} / 1$ respectivamente (5 


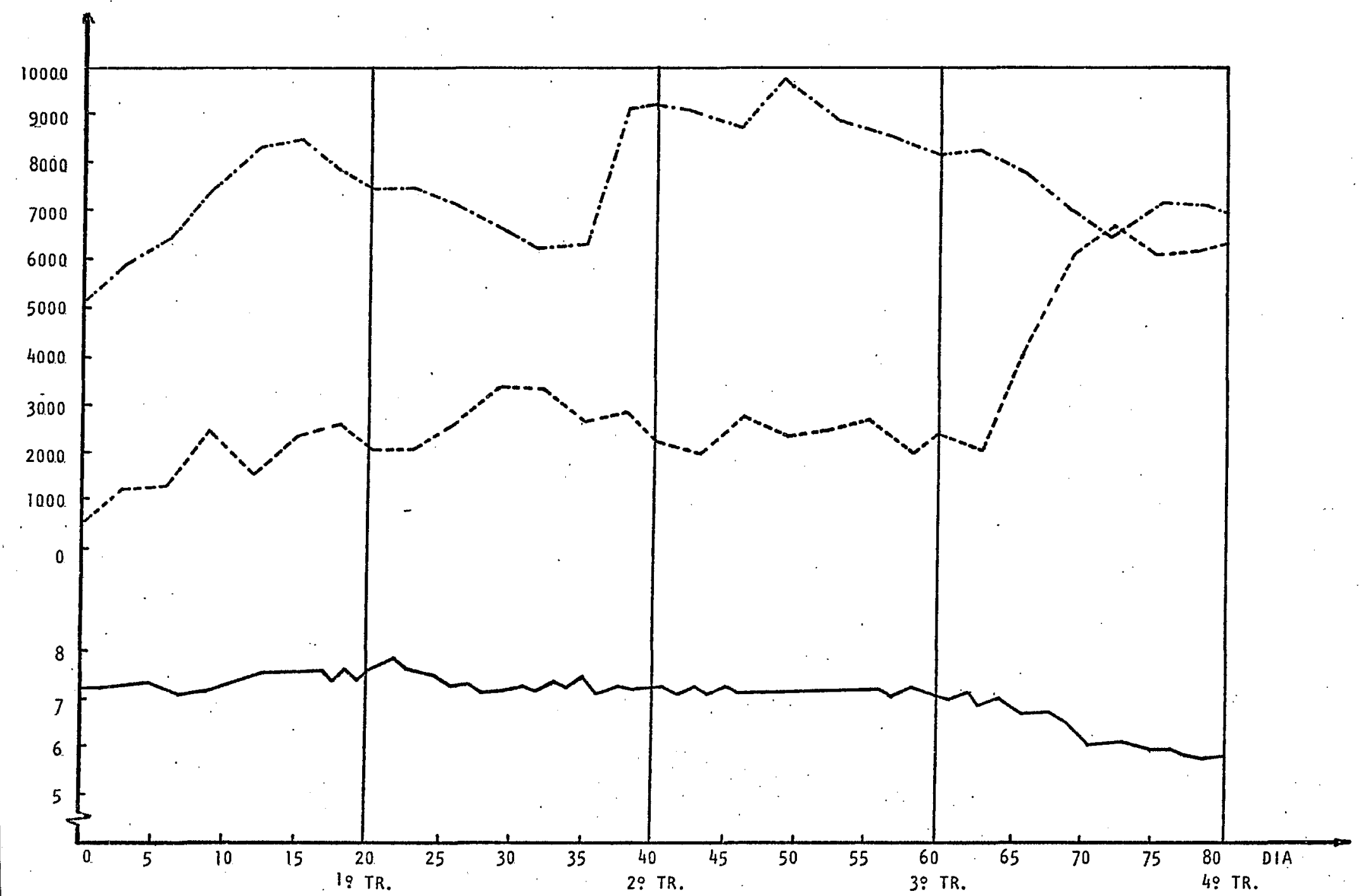

Figura 12: Valores de $\mathrm{pH}(-)$, acidez volätil expressa em mg $\mathrm{CH}_{3} \mathrm{COOH} / \mathrm{l}(---)$ e alcalini- $\mathrm{G}$ dade expressa em mg $\mathrm{CaCO}_{3} / 1\left(-.-\right.$ - $\left.^{-}\right)$do biodigestor 5 . 


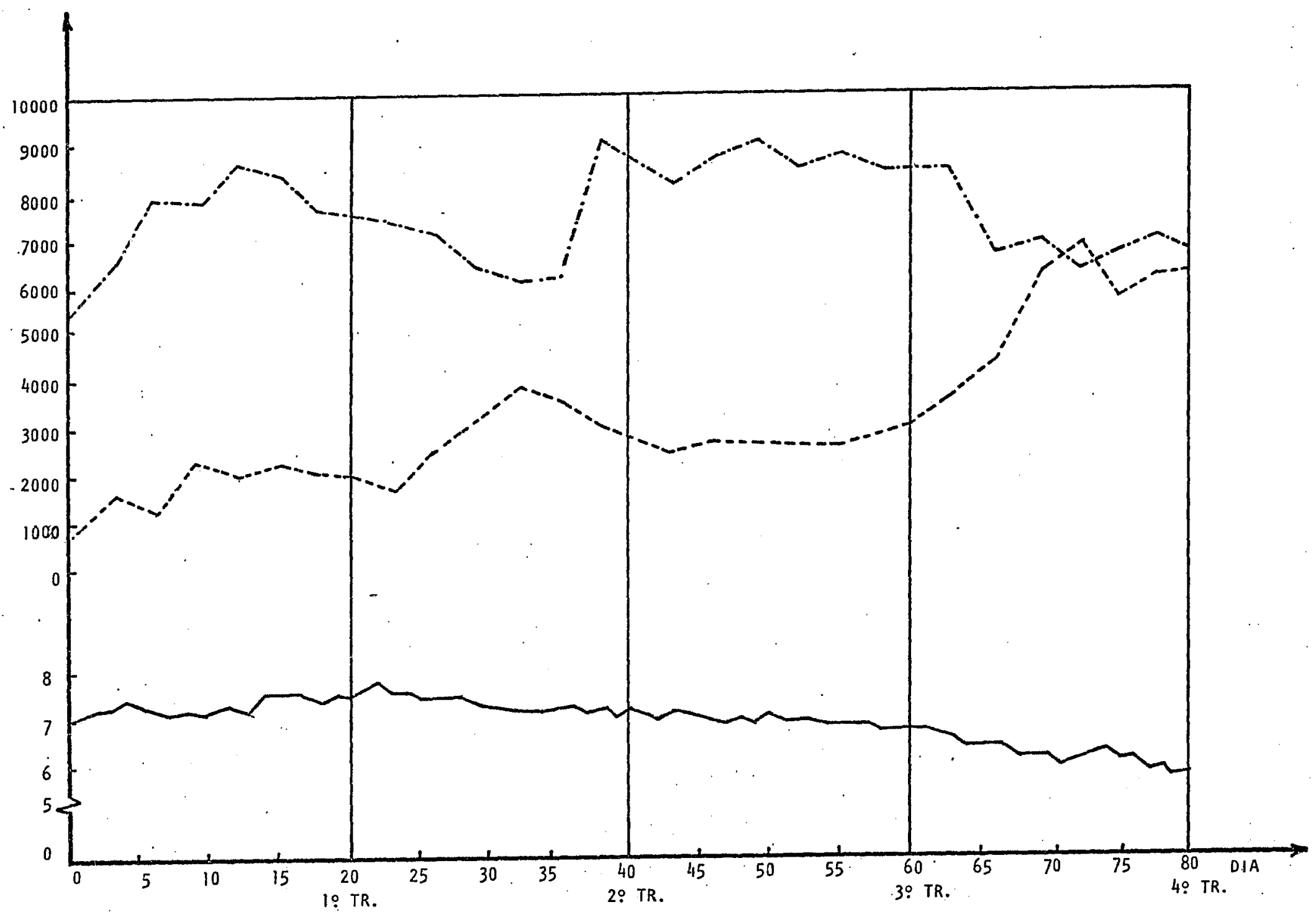

Figura 13: Valores de $\mathrm{pH}(-)$, acidez volätil expressa em $\mathrm{mg} \mathrm{CH}_{3} \mathrm{COOH} / \mathrm{l}(---)$ e alcalinidade expressa em mg $\mathrm{CaCO}_{3}(-. .-)$. do biodigestor 6 . 
e 6) e no final deste tempo esta se encontrava em aproximadamente 2.200-2.700 mg CH $\mathrm{COOH} / 1$ (5-6). No 39TR a acidez não oscilou (intervalos de alimentação igual a 6 horas) e no 49TR a acidez cresceu rapidamente alcançando no final deste concentração de acidez de $6.150 \mathrm{mg} \mathrm{CH}_{3} \mathrm{COOH} / 1$; com a carga adicionada de uma só vez.

Neste tratamento, a acidez volätil prejudicou a digestão anaeróbica quando ocorreu a queda do pH, pois mesmo encontrando-a nas faixas tolerāveis esta tornou-se tóxica ao sistema como citado por McCARTY \& McKYNNEY (1961). A queda do pH é explicada com a não divisão da carga orgānica adicionada, isto é, com a adição total da carga $(5,38 \mathrm{~g} \mathrm{DQO/dia)} \mathrm{a} \mathrm{produção} \mathrm{de} \mathrm{äcidos} \mathrm{foi} \mathrm{räpida} \mathrm{no} \mathrm{iní-}$ cio do tratamento e não conseguindo degradá-los até a adição subsequente, mesmo com níveis de alcalinidade elevados.

A alcalinidade inicial no 1 QTR oscilou entre $5.200-5.400 \mathrm{mg} \mathrm{CaCO}_{3} / 1$. Com a correção de pH do soro com bicarbonato de sódio a 6,5 a alcalinidade aumentou acentuadamente até ofinal do $290 \mathrm{TR}(9.000 \mathrm{mg} \mathrm{CaCO} / 1)$ e não se alterou no $39 T R$. No final do 49TR a alcalinidade diminuiu

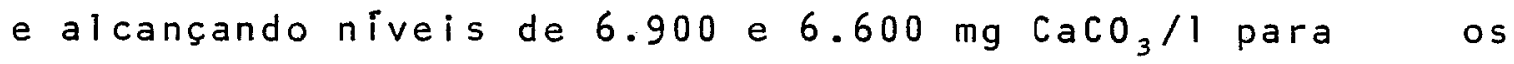
biodigestores 5 e 6 respectivamente.

Assim, nas condições do experimento sem correção do $\mathrm{pH}$ do soro de alimentação, independente da subdi visão da carga de DQO adicionada diariamente, o acümulo 
de äcidos voläteis e a queda do $\mathrm{pH}$ dos biodigestores 1 e 2 no final do 2oTR impediu o bom desempenho da digestão anaeröbica nos TR subsequentes, o que não ocorreu com os biodigestores $3,4,5$ e 6 onde houve uma correção inicial do pH do soro de alimentação. Nesses tratamentos atē o final do 39TR (onde houve o parcelamento da carga de DQO adicionada) foi conseguido o tamponamento do meio, o que não ocorreu no 49TR onde a carga de DQO não foi parcelada e a concentração de äcidos desses biodigestores praticamente paralizou a digestão anaeröbica.

4.2. Eficiência da Digestão Anaeróbica do Soro de Queijo em Relação à Remoção de $D Q 0$ e Produção de Biogās

A eficiência da biodegradação do material orgânico do soro de queijo foi caracterizada pela anälise de DQO no efluente centrifugado. Os resultados obtidos no experimento encontram-se nas Tabelas 10,11 e 12 do Apêndice e nas Figuras $14,15,16,17,18$ e 19 .

A produção de biogās ( 1 biogās/dia) obtida é encontrada nas Tabelas $13,14,15$ e 16 do Apéndice e Figuras $14,15,16,17,18$ e 19 .

Segundo citações de GRYSCHEK \& BELO (1983) o rendimento da digestão anaeróbica é grandemente afetado pela 


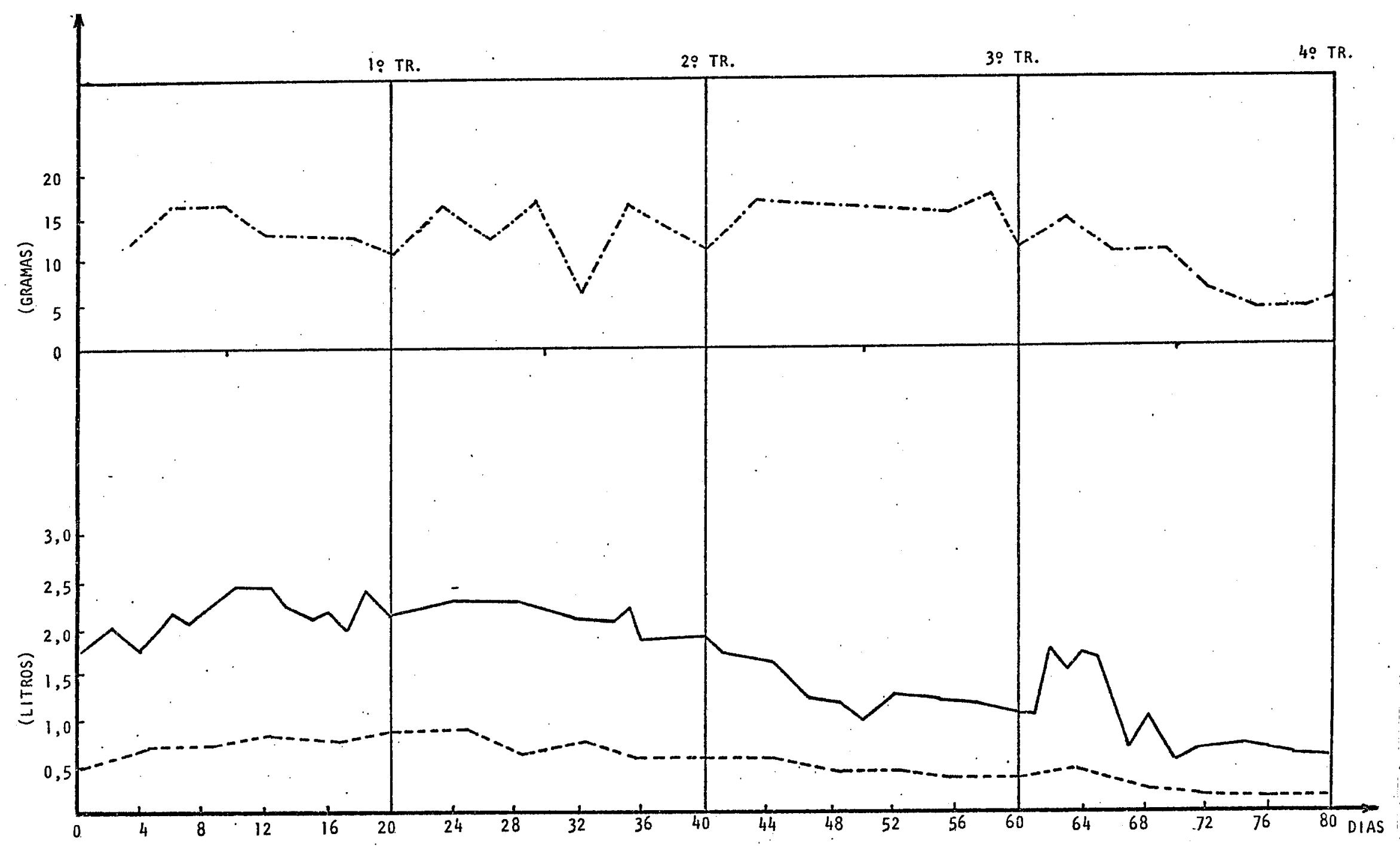

Figura 14: Produção de biogās (-), teor de metano no biogás (---) e grama de DQ0 removida em função do tempo (-...-) utilizando $5,38 \mathrm{~g}$ DQo/dia de soro, no biodigestor 1 . 


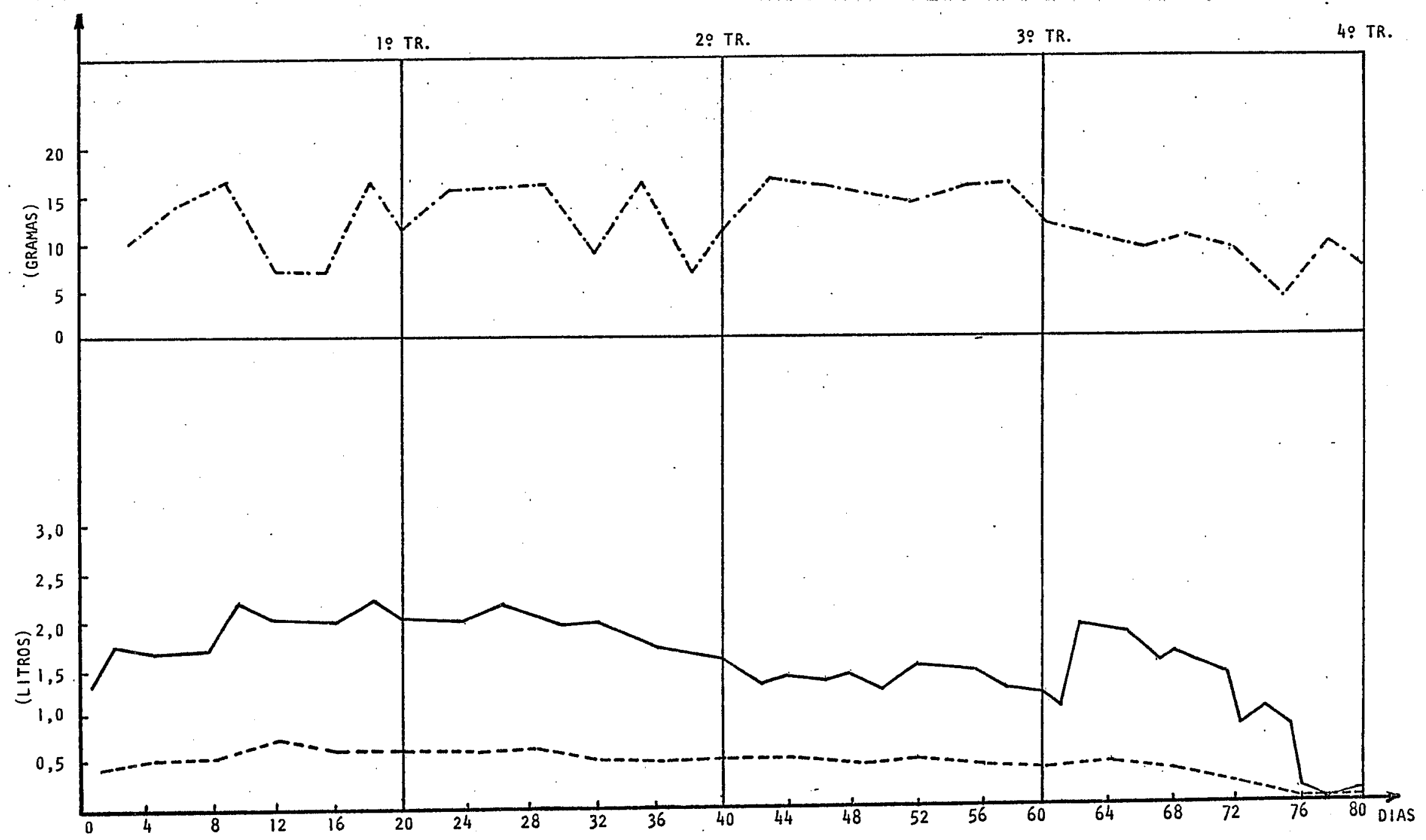

Figura 15: Produção de biogās (-), teor de metano no biogās (---) e grama de DQO removida em função do tempo (-...) utilizando $5,38 \mathrm{~g}$ DQO/dia de soro, biodigestor 2. 


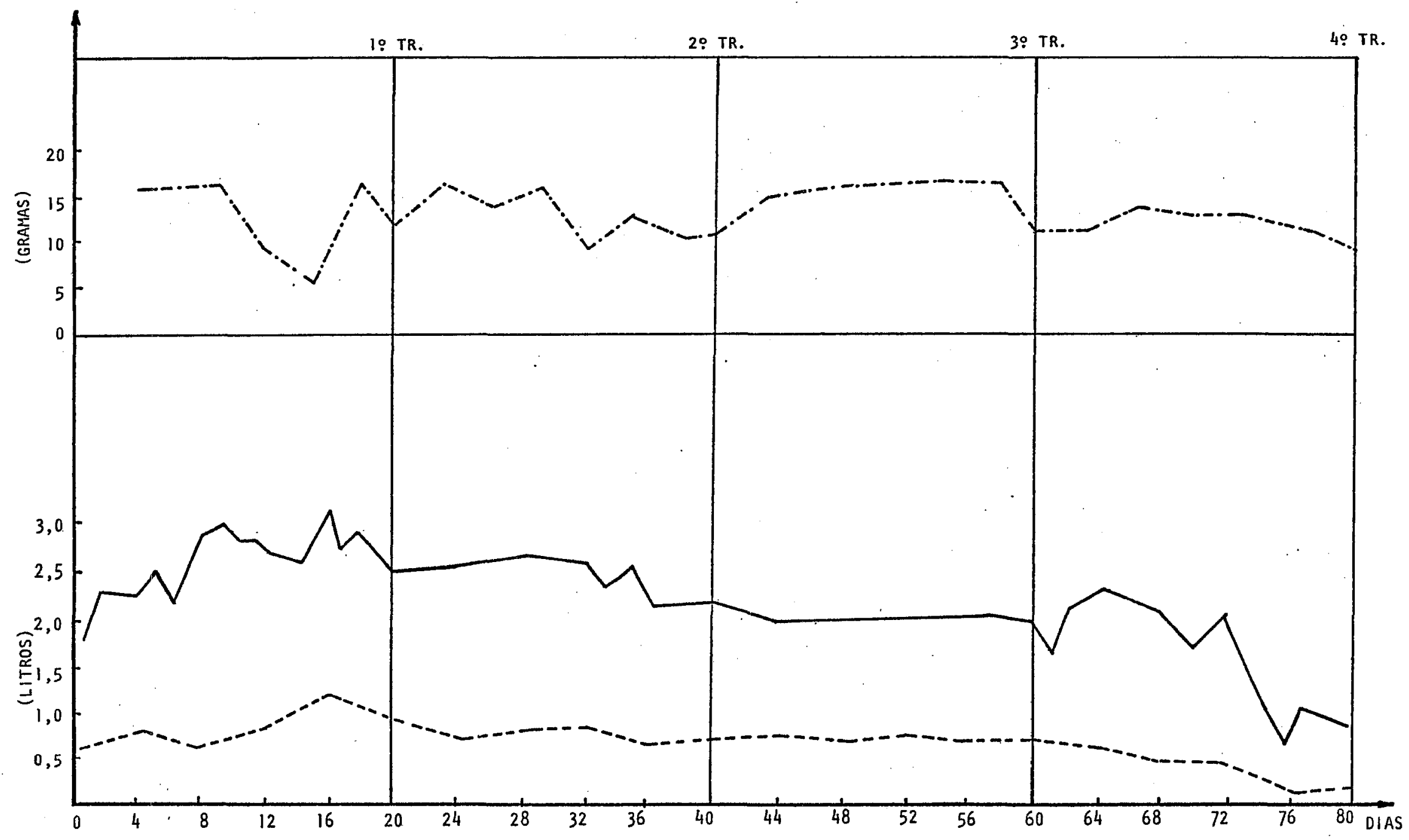

Figura 16: Produção de biogās (-), teor de metano no biogás (---) e grama de DQ0 removida em função do tempo (-..-) utilizando $5,38 \mathrm{~g} \mathrm{DQ0/dia} \mathrm{de} \mathrm{soro,} \mathrm{no} \mathrm{bio-}$ digestor 3 . 


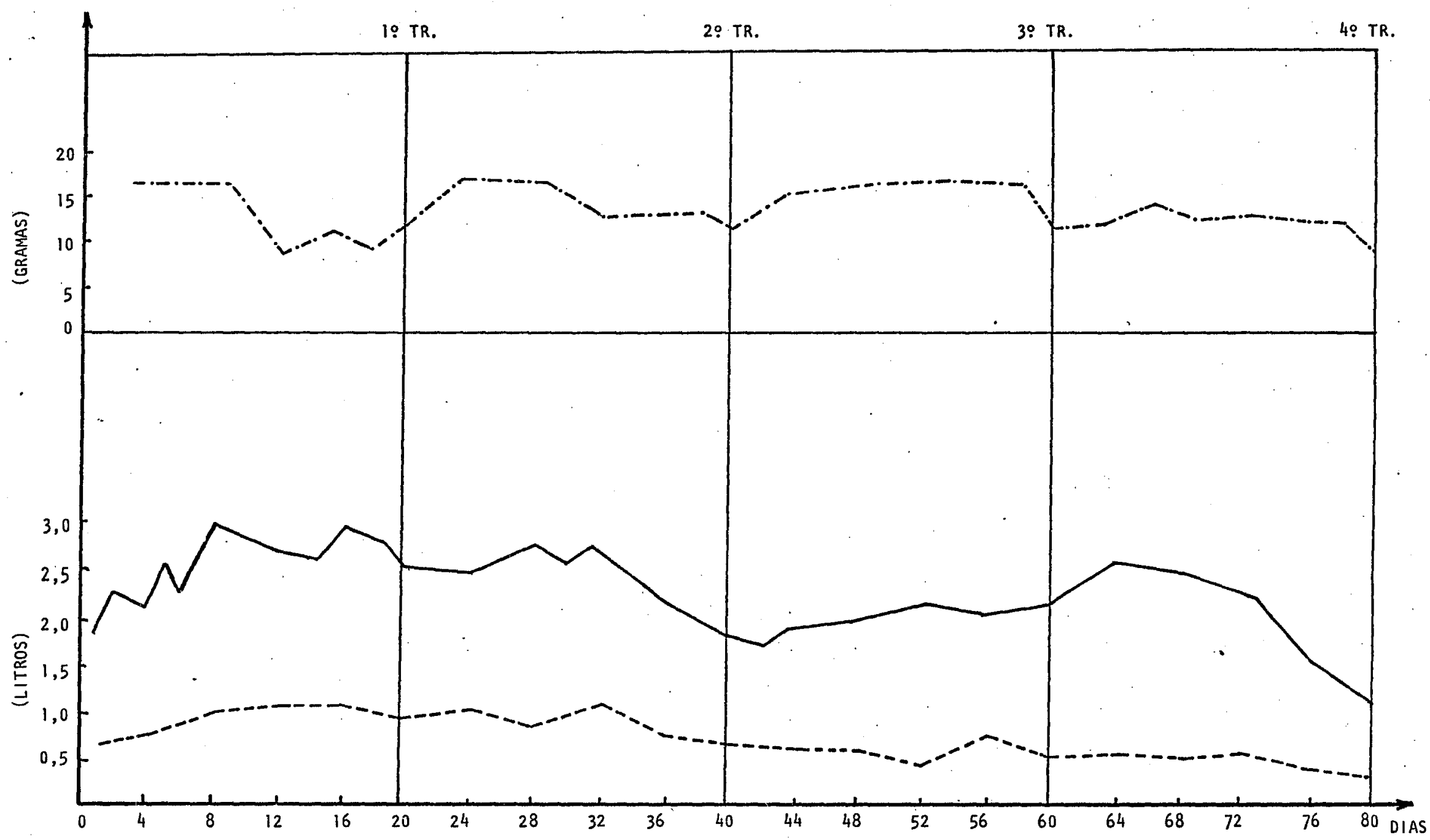

Figura 17: Produção de biogás (-), teor de metano no biogäs (---) e grama de DQ0 removida em função do tempo (-...) utilizando $5,38 \mathrm{~g}$ DQO/dia de soro, no biodigestor 4 . 


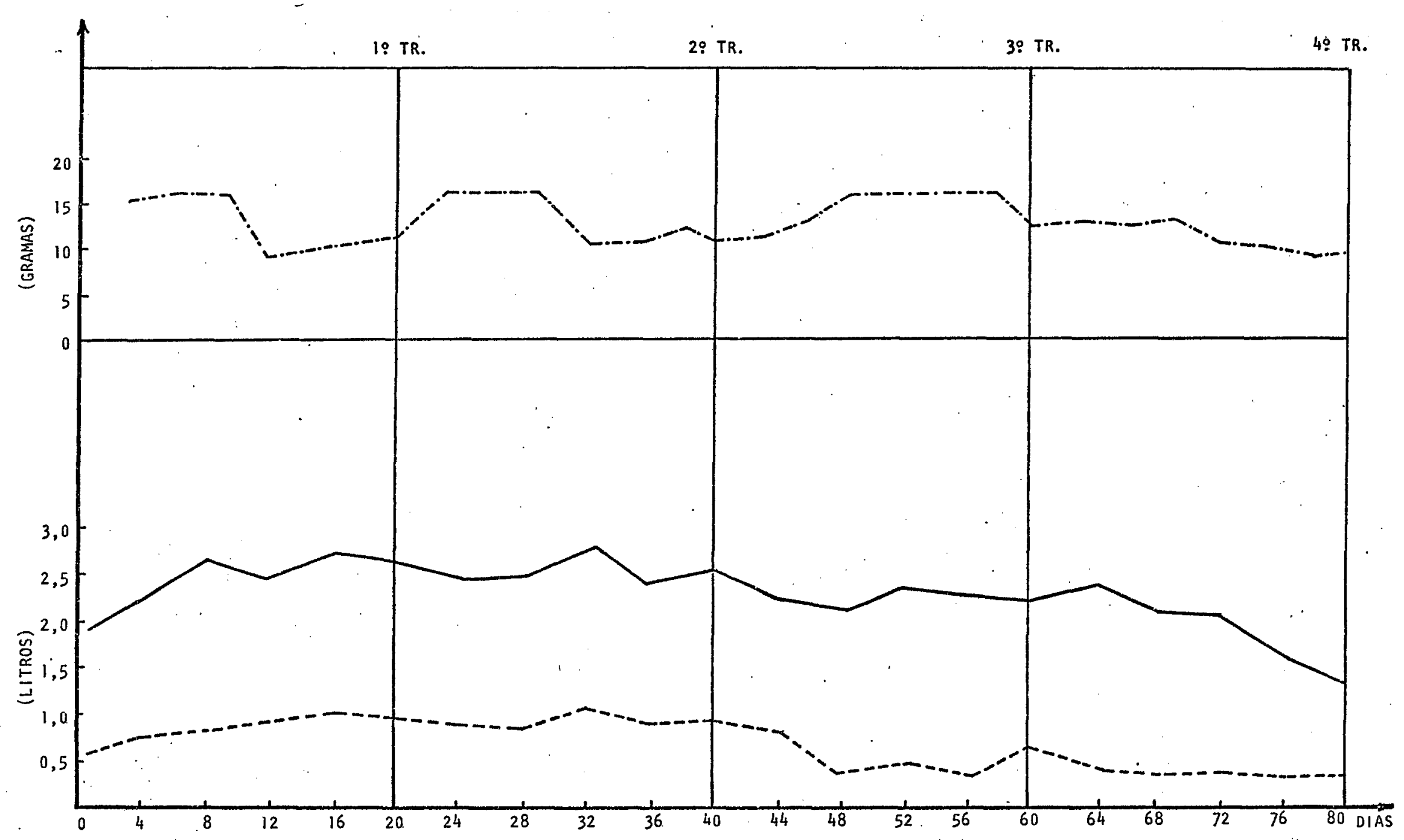

Figura 18: Produção de biogäs (-), teor de metano no biogäs (---) e grama de DQ0 removida em função do tempo (-...-) utilizando $5,38 \mathrm{~g}$ DQO/dia de soro, no biodigestor 5 . 


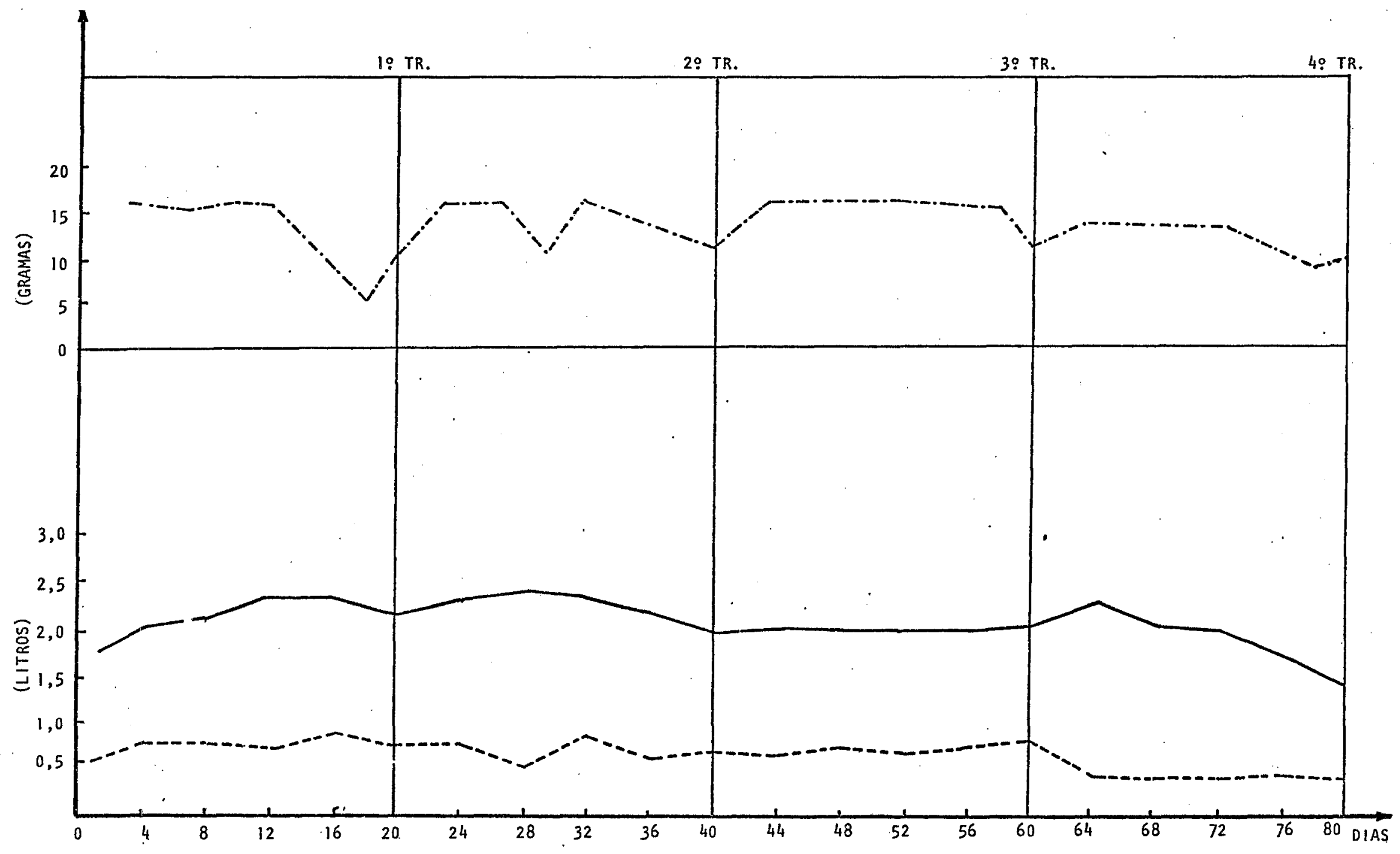

Figura 19: Produção de biogās (-), teor de metano no biogās (---) e grama de DQ0 removida em função do tempo (-...-) utilizando $5,38 \mathrm{~g}$ DQO/dia de soro, biodigestor 6 .

ט 
composição química do resíduo. Como exemplo os mesmos autores citam que, resíduos contendo baixa digestibilidade como residuos fibrosos (bagaco de cana e residuos agrícolas) apresentam potenciais mais reduzidos quando comparado com resíduos contendo alta digestibilidade ( resíduos de matadouros e laticinios).

A digestão anaeröbica do soro de queijo, um resíduo de alta digestibilidade, é tambēm afetada pelo tipo de biodigestor empregado (SOUZA, 1982a).

Como exemplo, utilizando biodigestores

não convencionais como o caso de LO \& LIAO (1986a e b) (biodigestores de escala laboratorial de contato) conseguiram remoções de DQO que variavam de 76 a $93 \%$; já HOLDER \& SEWARDS, citado por BARFORD (1986) utilizando tratamento similar ao citado anteriormente obtiveram remoções de $90 \%$. HICKEY $\varepsilon$ OWENS (1980) conseguiram remover $83,6 \%$ de DQO utilizando uma carga de $13,4 \mathrm{~kg} D Q 0 / \mathrm{m}^{3}$.dia no $T R=1,4$ dia em biodigestores de leito fluidizado.

Comparando os resultados obtidos de remoção de DQO com o tipo de biodigestor utilizado neste experimento (Figura, 6), as remoções de DQO variaram bastante e os biodigestores $\left(\begin{array}{lll}1 & \text { e } & 2\end{array}\right)$ que foram alimentados com soro de queijo sem correção de $\mathrm{pH}$ foram os que obtiveram menor remoção de DQO (Tabela 20). 
Os melhores rendimentos da digestäo anaeróbica expressos em 1 de biogás produzido/g DQO removida, obtidos nos biodigestores foram encontrados nos 19 e $20 T R$ como mostram as Tabelas 17,18 e $19, \quad$ onde a carga de alimentação foi parcelada em 3 e 2 vezes respectivamente. No 3 oTR a remoção de DQO alcançada foi bastante elevada, mas o rendimento em biogás neste TR foi baixo (Tabela 20). Isto poderia ser fundamentado no fato de que, com o parcelamento da carga de alimentação em 4 vezes, isto é, com a abertura dos biodigestores, o contato do material digerido com o ar foi bem maior do que nos TR anteriores.

No 49TR a remoção de DQO decresceu acentuadamente em todos biodigestores mais o rendimento em biogás me1 horou quando comparado com o $39 T R$, pois a carga de DQO foi adicionada de uma só vez, o que levou a uma maior condição de anaerobiose do sistema e consequentemente uma melhoria na atividade das bactérias metanogēnicas. 


\section{CONCLUSÕES}

Nas condições do presente trabalho os resultados encontrados para os quatro tempos de retenção e sistemas de alimentação levam as seguintes conclusões:

1) Os sistemas de alimentação utilizados no presente trabalho prejudicaram o desenvolvimento da digestão anaeröbica, afetando as condições de anaerobiose, principalmente quando a carga total de DQO (3OTR) fora parcelada, com alimentação de 6 em 6 horas.

2) A alimentação de uma só vez, da carga total de DQO (49TR) por outro lado, provocou um aumento muito rápido da concentração de acidez volátil o que levou consequentemente a uma diminuição drāstica da digestão anaeróbica e consequentemente diminuição da produção de biogãs.

3) Comparando-se a remoção de $D Q O$ em relação à correção do $\mathrm{pH}$, verifica-se que com correção do pH do soro de al imentação houve uma maior eficiência na remoção de DQO. 
4) A correção do $\mathrm{pH}$ do soro de alimentação,independentemente do sistema de alimentação, aumentou a produçāo de metano.

5) Não foram constatadas diferenças na produção de metano para os dois níveis de correção do $\mathrm{pH}(5,5$ e $6,5)$ do soro de alimentação. 


\section{REFERENCIAS BIBLIOGRÁFICAS}

AMERICAN PUBLIC HEALTH ORGANIZATION. Standard Methods for Examination of water and wastewater, $14 \mathrm{ed}$. Washington, D. C. APHA. American Public Health Organization, 1976.

ARAúJo, E.H.; MElo, G.S.; OLIVEIRA, I. Operação de biodigestor anaeróbico em escala de bancada para produção de biogàs a partir de soro de queijo. Revista de Microbiologia, São Paulo, 17(2): 155-161, 1986.

BARBOSA, R.A. Novas Tecnologias em. Biodigestores. In: SIMPÓSIO NACIONAL DE FERMENTAÇÃO. DA UNIVERSIDAdE DE VIÇOSA, 5. Viçosa, 1982. Anais, Viçosa, Universidade Federal de Vi çosa, 1986 .

BARFORD, J.P.; CAIL, R.G.; CALLENDER, I.J.; FLOYD, E.J. Anaerobic Digestion of High-Strenght Cheese Whey Utilizing Semicontinous Digesters and Chemical Floculant Addition. Riotecnology and Bioengineering, New York, 28: 1601-07, 1986. 
BARKER, H.A. Lectures in Microbial Biochemistry Bacterial Fermentations. New York, John Wiley e Sons, Inc. London Chapman e Hall Ltda., CIBA, 1956.

BATISTA, L.F. Construção e operação de biodigestor modelo Indiano. Energia - Fontes Alternativas, São Paulo, 3(15): $38-56,1981$.

BOENING, P.H. \& LARGEN, V.F. Anaerobic Fluidezed Bed Whey Treatment. Biotechnology and Bioengineering, New York, $24(11): 2539-56,1982$

BRYANT, M.P. Microbial methane production. Theoretical Aspects. Journal of Animal Science, New York, 48(1): 193$-201,1979$.

BYLUND, G. Tratamento e utilização do soro. Revista do Instituto de Laticinios cândido Tostes, Juiz de Fora, 30 $(179): 29-43,1975$.

CEREDA, M.P.; FLORS, A.; VALLES, S.; ALBEROA, J. Tratamiento anaerobio en dos fases de suspensiones amiláceos. 1 . Fase acidogēnica. Revista de Agroquímica y Tecnologia de Alimentos, Madrid, 26(1): 101-08, 1986.

costa, c. Biotecnologia e a Produção de Energia, Piracicaba, E.S.A. "Luiz de Queiroz" - Universidade de São Paulo, 1986, $183 \mathrm{p}$ 
COSTA, S.R.A. E LACAVA, P.M. Observações preliminares da digestão anaeróbica do soro de queijo. In: SEMINĀRIO REGIONAL DE ECOLOGIA DA UNIVERSIDADE FEDERAL DE SÃO CARLOS, 5. São Carlos, 1986. Anais, São Carlos, Universidade Federal de São Carlos, 1986. 1v.

CRAVEIRO, A.M. Produção de biogäs. In: SIMPósIO NACIONAL DE FERMENTAÇÃo de RECIFE. 4. Recife, 1986. Anais, Universidade Federal de Recife, 1986. 1v.

DANESE, M. Utilização do biogãs. Energia - Fontes Alternativas, São Paulo, 3(15): 14-19, 1981.

DE LA TORRE, I. E GOMA, G. Characterization of Anaerobic Microbial Culture with High Acidogenic Activity. Biotechnology and Bioengineering, New York, 23: 185-199, 1981.

DITCHFIELD, P. Industrial wastewater treatment: the anaerobic alternative. Trends Biotecnology, Amsterdam, p. 309-313, DEC, 1986.

FERRAT, A. Como valorizar o subproduto das fäbricas de queijos, o "Lacto-Soro". Boletim do Leite, Rio de Janeiro, $618: 32-38,1980$.

FOLLMANN, H. E MÄRKL, H. pH-satisches Verfahzenzur Kontinuierlichen Anaeroben Vergärung von Hochbelasteten Abwassern zu Methan 2. Eperimentelle Untersu Chungen und Verifizierung des Konzeptes an Beispiel der Molke. Mil 
Chwissen schaft, Hermann, 34(7): 393-396, 1979.

GONCGALES, A.C.R. A potencialidade de outros substratos para a digestão anaeróbica. In: SIMPÓSIO NACIONAL DE FERMENTAÇÃo, 5., Viçosa, 1982. Anais, Universidade Federal de Viçosa, 1982. 1v.

GRŸSCHEK, J.M. E BELO, F.R. Produção e Uso do Gäs Metano na Agricultura e Agro-indūstria, E.S.A. "Luiz de Queiroz" Universidade de São Paulo, 1983. 15p.

HARISCHANDRA, H.C. E SAVENA, K.L. Anaerobic Digestion of Cheese Whey Utilizing Sistem of Agitation in Digester. Environmental Health, $11(1): 41-50,1969$.

HICKEY, R.F. E OWENS, R.W. Third Symposium Biotechnology in Energy Production and Conservation, Gat linburg, Tennessec, 1981 .

HUGHES, D.E. What is anaerobic digestion? On over view. In: STAFFORD, D.A; WHEATLEY, B.I.; hughes, D.E. Anaerobic Digestion, London, Applied Science Publishers, 1980, $1-14$.

IZAGUIRRE, M.E. E CASTILLO, F.L. Selection of lactose fermenting yeast for ethanol production from whey. Biotecnology Letters, London, 4: 251, 1982. 
INSTITUTO DE DESENVOLVIMENTO INDUSTRIAL DE MINAS GERAIS. A Industrial de Laticinios de Minas Gerais, Belo Horizonte, INDI, 1980, 1v.

KOSIKOWSKI, F. Greater utilization of whey powder for human comsumption and nutrition. Journal of Dairy Science, New York, 50: 1343-45, 1967.

KUBIAK. C. E DUBUIS, T. Valorização dos dejetos e dos efluentes agrícolas, industriais e domésticos. In: SCRIBAN, R., Biotecnologia, Manole, 1985, 400-26.

LO, K.V. \& LIAO, P.H. Digestion of cheese whey with anaerobic rotating biological contact reactores. Biomass, 10 : $243-252,1986 a$.

LO, K.V. E LIAO, P.H. Two-stage anaerobic digestion of cheese whey. Biomass, 10:319-322, $1982 \mathrm{~b}$.

MAH, R.A.; WARD, D.M.; BARESI, L. \& GLASS, T.L. Biogenisis of methane. Annual Review of Microbiology, 31: 309-342, 1977.

MCCARTY, P.L. E MCKINNEY, R.E. Volatile acid toxicity in anaerobic digestion. Journal W.P.C.F., Washington, (3): $223-32, ; 961$.

PERES, C.S. Microbiologia da Digestão Anaerōbica. São Paulo, Instituto de Pesquisas Tecnológicas - IPT, Divisão de - Química, 1982. 40p. (mimeografado). 
REESEN, L. E STRUBE, R. Complete utilization of whey for alcohol and methane production. Process Biochemistry, London, p.21-24, nov., 1979.

SILVA, N.A. O biogás e o biofertilizante no balanço energètico do Brasil. Revista DAE, São Paulo, 44(136): 22 $-29,1984$.

SILVA, M.o.S.A. Anälises Fisico-quimicas para controle de Estações de Tratamento de Esgatos. ABES/BNH/CETESB, 1977, $225 p$.

SoUZA, M.E. Fatores que Influenciam a Digestão Anaerōbica. São Paulo, CETESB, 1982a. 30p. (mimeografado).

- Problemātica da Digestão Anaerōbica dos Reséduos Industriais. São Paulo, CETESB, 1982b. 35p. (mimeografado).

SUTTON, P.M. \& LI, A. Proceedings of $36^{\text {th }}$. Industrial Waste Conference, Purdue University, 1981.

TOERIEN, D.F. E HATTINGH, W.H. Anaerobic Digestion. 1. The microbiology of anaerobic digestion. Water Research, 3 : $385-396,1969$.

VIEIRA, M.A.; BRANDÃO, S.C.C.; PINHEIRO, A.J.R.; GUIMARÃES, W.R. Conservação do soro de queijo minas com peróxido de hidrogènio. Revista do Instituto de Laticinios cândido Tostes, Juiz de Fora, 40.(240): 17-28, 1985. 
VIEIRA, S.M.M. E SOUZA, M.E. Métodos Analiticos para o Acompanhamento da Biodigestão. São Paulo, CETESB, 1981. 11p. (mimeografado).

WOLFE, R.S. Microbial Formation of Methane. In: Advances in Microbial Physiology, 6, Academic Press, London, 1971. p. 107-146.

ZEIKUS, J.G. The biology of methanogenic bacteria. Bacteriological Reviews, Washington, 40:514-541, 1977.

ZEIKUS, J.G. Microbial populations inidigesters. In: STAFFORD, D.A.; WHETLEY, B.Y. E HUGHES, D.E. Anaerabic Digestion, London, Applied Science Publishers, 1980. p.61-89 .

ZEIKUS, J.G. Microbial ecophysiology of whey biomethanation: Intermediary metabolism of lactose degradation in continous culture. Applied and Environmental Microbiology, Baltimore, 51(1): 180-187, 1986.

ZINDER, S.H. Microbiology of anaerobic conversion organic wastes to methane: Recent developments. ASM News, (7): $294-298,1984$.

- Will a recombinant DNA yeast be able to solve whey disposal problems? Trends Biotechnology, Amsterdan, 4 (5): $107-108,1986$. 
A PENDICE 
Tabela 7: Acidez volátil, alcalinidade e pH dos biodigestores 1 e 2 mantidos à $35^{\circ} \mathrm{C}$.

\begin{tabular}{|c|c|c|c|c|c|c|c|}
\hline \multirow{2}{*}{$\begin{array}{l}\text { Tempo } \\
\text { retenção }\end{array}$} & \multirow{2}{*}{ Dia } & \multirow{2}{*}{$\mid \begin{array}{c}\mathrm{pH} \\
\text { biodig. } \\
1\end{array}$} & \multirow{2}{*}{$\begin{array}{c}\mathrm{pH} \\
\text { biodig. } \\
2\end{array}$} & \multicolumn{2}{|c|}{ Acidez volātil } & \multicolumn{2}{|c|}{ Alcalinidade } \\
\hline & & & & biodig.1 & biodig. 2 & biodig. 1 & biodig.2 \\
\hline 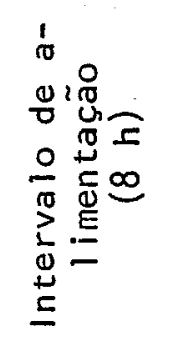 & $\begin{array}{l}0 \%: \\
3 \% \\
69 \\
9 \% \\
129 \\
15 \% \\
18 \% \\
20 \%\end{array}$ & $\begin{array}{l}7,02 \\
7,08 \\
6,84 \\
6,82 \\
6,84 \\
7,31 \\
7,10 \\
7,28\end{array}$ & $\begin{array}{l}7,08 \\
7,11 \\
7,05 \\
6,84 \\
6,83 \\
7,30 \\
7,32 \\
7,28\end{array}$ & $\begin{array}{r}484,8 \\
727,2 \\
1212,0 . \\
1212,0 \\
886,2 \\
379,4 \\
759,6 \\
759,6\end{array}$ & $\begin{array}{l}484,8 \\
848,4 \\
969,6 \\
969,6 \\
633,0 \\
633,0 \\
759,6 \\
886,2\end{array}$ & $\begin{array}{l}5.051,2 \\
4.706,8 \\
3.788,4 \\
4.160,0 \\
4.368,0 \\
4.264,0 \\
3.952,0 \\
3.848,0\end{array}$ & $\begin{array}{l}4.706,2 \\
5.051,2 \\
3.903,2 \\
5.096,0 \\
4.576,0 \\
4.368,0 \\
4.160,0 \\
3.848,0\end{array}$ \\
\hline 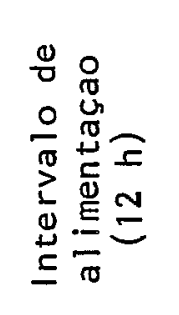 & $\begin{array}{l}23 \% \\
26 \% \\
29 \% \\
32 \% \\
35 \% \\
38 \% \\
40 \%\end{array}$ & $\begin{array}{l}7,26 \\
7,13 \\
7,10 \\
6,77 \\
6,81 \\
6,88 \\
6,40\end{array}$ & $\begin{array}{l}7,08 \\
6,92 \\
6,99 \\
6,69 \\
6,95 \\
6,60 \\
6,10\end{array}$ & $\begin{array}{r}886,2 \\
1139,4 \\
1407,5 \\
2942,9 \\
2942,9 \\
2047,2 \\
2303,1\end{array}$ & $\begin{array}{l}1392,6 \\
1899,0 \\
2431,1 \\
3326,7 \\
2431,1 \\
2303,1 \\
2686,9\end{array}$ & $\begin{array}{l}3.848,0 \\
3.640,0 \\
3.328,0 \\
3.120,0 \\
3.120,0 \\
4.822,4 \\
4.671,4\end{array}$ & $\begin{array}{l}3.848,0 \\
3.536,0 \\
3.432,0 \\
3.224,0 \\
3.952,0 \\
4.822,4 \\
4.973,1\end{array}$ \\
\hline 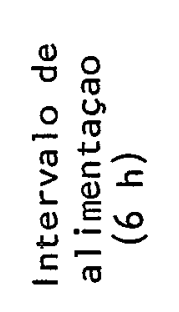 & $\begin{array}{l}430 \\
46 \% \\
490 \\
520 \\
55 \% \\
580 \\
60 \%\end{array}$ & $\begin{array}{l}6,40 \\
5,87 \\
5,60 \\
5,56 \\
5,58 \\
5,73 \\
5,74\end{array}$ & $\begin{array}{l}5,70 \\
5,48 \\
5,43 \\
5,39 \\
5,36 \\
5,35 \\
5,34\end{array}$ & $\begin{array}{l}2303,1 \\
2559,0 \\
4350,3 \\
4094,4 \\
4350,3 \\
4350,3 \\
4521,0\end{array}$ & $\begin{array}{l}2814,9 \\
3582,6 \\
3966,5 \\
3838,5 \\
3966,5 \\
3582,6 \\
3582,6\end{array}$ & $\begin{array}{l}4.521,0 \\
4.068,9 \\
4.219,6 \\
3.848,0 \\
4.219,6 \\
4.068,0 \\
4.521,0\end{array}$ & $\begin{array}{l}4.671,7 \\
4.521,0 \\
5.123,8 \\
5.123,8 \\
4.973,1 \\
4.521,0 \\
4.521,0\end{array}$ \\
\hline 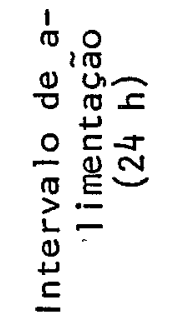 & $\begin{array}{l}630 \\
660 \\
690 \\
720 \\
750 \\
780 \\
80 \%\end{array}$ & $\begin{array}{l}5,80 \\
5,17 \\
5,00 \\
4,68 \\
4,67 \\
4,59 \\
4,51\end{array}$ & $\begin{array}{l}5,43 \\
5,17 \\
4,79 \\
5,06 \\
4,72 \\
4,40 \\
4,38\end{array}$ & $\begin{array}{l}4521,0 \\
5606,0 \\
6871,9 \\
7776,1 \\
6329,4 \\
6510,2 \\
6871,9\end{array}$ & $\begin{array}{l}3073,6 \\
3797,6 \\
3978,5 \\
5786,9 \\
6148,6 \\
6871,9 \\
6510,2\end{array}$ & $\begin{array}{l}4.068,0 \\
4.068,0 \\
3.390,0 \\
2.559,0 \\
2.373,0 \\
2.260,0 \\
2.373,0\end{array}$ & $\begin{array}{l}4.972,0 \\
4.294,0 \\
4.746,0 \\
3.955,0 \\
2.938,0 \\
2.260,0 \\
2.260,0\end{array}$ \\
\hline
\end{tabular}


Tabela 8: Acidez volátil, alcalinidade e pH dos biodigestores 3 e 4 mantidos à $35^{\circ} \mathrm{C}$

\begin{tabular}{|c|c|c|c|c|c|c|c|}
\hline \multirow{2}{*}{$\begin{array}{l}\text { Tempo } \\
\text { re tenção }\end{array}$} & \multirow{2}{*}{ Dia } & \multicolumn{2}{|c|}{$\mathrm{pH}$} & \multicolumn{2}{|c|}{ Acidez volātil } & \multicolumn{2}{|c|}{ Alcalinidade } \\
\hline & & Biodig. 3 & biodig. 4 & Biodig. 3 & Biodig. 4 & Biodig. 3 & Biodig. 4 \\
\hline 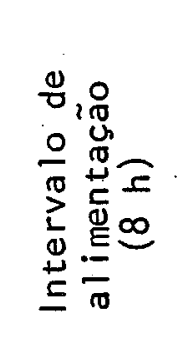 & $\begin{array}{r}0 \% \\
3 \% \\
6 \% \\
9 \% \\
12 \% \\
15 \% \\
18 \% \\
20 \%\end{array}$ & $\begin{array}{l}7,04 \\
6,98 \\
6,99 \\
6,84 \\
6,85 \\
7,36 \\
7,35 \\
7,32\end{array}$ & $\begin{array}{l}7,01 \\
7,10 \\
7,05 \\
6,92 \\
6,99 \\
7,38 \\
7,39 \\
7,38\end{array}$ & $\begin{array}{r}606,0 \\
727,2 \\
1.212,0 \\
1.333,2 \\
1.899,0 \\
1.239,4 \\
1.266,0 \\
1.392,6\end{array}$ & $\begin{array}{r}363,8 \\
969,6 \\
1.212,0 \\
1.212,0 \\
1.139,4 \\
1.266,0 \\
1.012,8 \\
1.266,0\end{array}$ & $\begin{array}{l}5.051,2 \\
4.936,4 \\
4.477,2 \\
5.200,0 \\
5.304,0 \\
5.200,0 \\
5.096,0 \\
4.992,0\end{array}$ & $\begin{array}{l}6.199,2 \\
5.166,0 \\
4.592,0 \\
6.344,0 \\
5.512,0 \\
5.512,0 \\
5.200,0 \\
4.888,0\end{array}$ \\
\hline 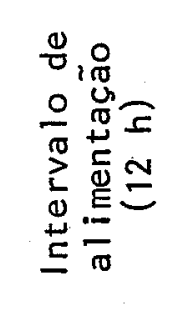 & $\begin{array}{l}23 \% \\
26 \% \\
29 \% \\
32 \% \\
35 \% \\
38 \% \\
40 \%\end{array}$ & $\begin{array}{l}7,37 \\
7,23 \\
7,24 \\
6,98 \\
6,95 \\
6,71 \\
6,86\end{array}$ & $\begin{array}{l}7,39 \\
7,21 \\
7,29 \\
7,14 \\
7,27 \\
7,28 \\
6,84\end{array}$ & $\begin{array}{r}886,2 \\
1.392,6 \\
2.303,1 \\
2.559,0 \\
2.559,0 \\
1.919,3 \\
3.582,6\end{array}$ & $\begin{array}{r}759,6 \\
1.645,8 \\
2.559,0 \\
2.175,1 \\
1.919,3 \\
2.047,2 \\
2.047,2\end{array}$ & $\begin{array}{l}4.992,0 \\
4.680,0 \\
4.264,0 \\
4.680,0 \\
4.368,0 \\
6.329,4 \\
6.932,2\end{array}$ & $\begin{array}{l}5.304,0 \\
4.888,0 \\
4.576,0 \\
4.576,0 \\
4.992,0 \\
6.622,0 \\
7.535,0\end{array}$ \\
\hline 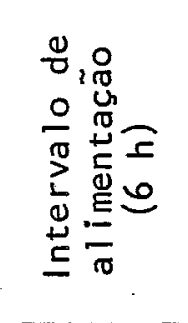 & $\begin{array}{l}43 \% \\
46 \% \\
49 \% \\
52 \% \\
55 \% \\
58 \% \\
60 \%\end{array}$ & $\begin{array}{l}6,95 \\
6,70 \\
6,66 \\
6,63 \\
6,58 \\
6,59 \\
6,52\end{array}$ & $\begin{array}{l}6,87 \\
6,68 \\
6,76 \\
6,77 \\
6,80 \\
6,74\end{array}$ & $\begin{array}{l}2.175,1 \\
3.070,8 \\
2.559,0 \\
2.431,1 \\
2.559,0 \\
2.175,1 \\
1.919,3\end{array}$ & $\begin{array}{l}2.559,0 \\
2.942,9 \\
2.814,9 \\
2.559,0 \\
2.431,1 \\
1.808,4 \\
1.808,4\end{array}$ & $\begin{array}{l}6.630,8 \\
6.178,7 \\
7.082,9 \\
6.622,0 \\
6.622,0 \\
6.329,4 \\
6.630,8\end{array}$ & $\begin{array}{l}6.932,2 \\
6.630,8 \\
7.233,6 \\
7.082,9 \\
6.968,0 \\
6.630,8 \\
6.630,8\end{array}$ \\
\hline 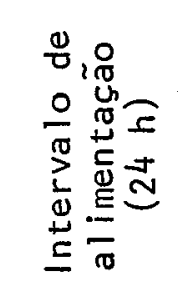 & $\begin{array}{l}63 \% \\
66 \% \\
69 \% \\
72 \% \\
75 \% \\
78 \% \\
80 \%\end{array}$ & $\begin{array}{l}6,53 \\
6,53 \\
6,27 \\
5,80 \\
5,58 \\
5,21 \\
5,19\end{array}$ & $\begin{array}{l}6,73 \\
6,49 \\
6,39 \\
6,14 \\
5,98 \\
5,72 \\
5,60\end{array}$ & $\begin{array}{l}1.808,4 \\
3.616,8 \\
4.521,0 \\
5.063,5 \\
5.063,5 \\
5.786,9 \\
6.010,8\end{array}$ & $\begin{array}{l}1.808,4 \\
2.712,6 \\
4.882,7 \\
5.425,2 \\
5.063,5 \\
5.244,4 \\
5.425,2\end{array}$ & $\begin{array}{l}6.780,0 \\
5.763,0 \\
5.537,0 \\
5.311,0 \\
5.650,0 \\
5.537,0 \\
5.763,0\end{array}$ & $\begin{array}{l}6.780,0 \\
6.215,0 \\
5.989,0 \\
5.311,0 \\
5.424,0 \\
5.763,0 \\
5.424,0\end{array}$ \\
\hline
\end{tabular}


Tabela 9: Acidez volátil, alcalinidade e pH dos biodigestores 5 e 6 mantidos à $35^{\circ} \mathrm{C}$

\begin{tabular}{|c|c|c|c|c|c|c|c|}
\hline \multirow{2}{*}{$\begin{array}{c}\text { Tempo } \\
\text { retenção }\end{array}$} & \multirow{2}{*}{ Dia } & \multicolumn{2}{|c|}{$\mathrm{pH}$} & \multicolumn{2}{|c|}{ Acidez.volätil } & \multicolumn{2}{|c|}{ Alcalinidade } \\
\hline & & Biodig. 5 & Biodig. 6 & Biodig. 5 & Biodig. 6 & Biodig. 5 & Biodig. 6 \\
\hline 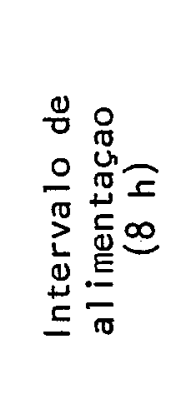 & $\begin{array}{r}0 \% \\
3 \% \\
6 \% \\
9 \% \\
12 \% \\
15 \% \\
18 \% \\
20 \%\end{array}$ & $\begin{array}{l}7,05 \\
7,20 \\
7,16 \\
7,06 \\
7,40 \\
7,50 \\
7,50 \\
7,48\end{array}$ & $\begin{array}{l}7,04 \\
7,19 \\
7,14 \\
7,10 \\
7,18 \\
7,53 \\
7,33 \\
7,35\end{array}$ & $\begin{array}{r}-\mathrm{mg} \text { ac. } \\
484,8 \\
1.212,0 \\
1.333,2 \\
2.424,0 \\
1.519,2 \\
2.278,8 \\
2.532,0 \\
2.025,6\end{array}$ & $\begin{array}{r}727,2 \\
1.575,6 \\
1.212,0 \\
2.302,8 \\
2.025,6 \\
2.152,2 \\
2.025,6 \\
2.025,6\end{array}$ & $\begin{array}{c}-\mathrm{mg} \mathrm{Ca} \\
5.280,8 \\
5.854,8 \\
6.314,0 \\
7.384,0 \\
8.320,0 \\
8.424,0 \\
7.800,0 \\
7.488,0\end{array}$ & $\begin{array}{r}\mathrm{CO}_{3} / 1 \\
5.395,6 \\
6.314,0 \\
7.806,4 \\
7.696,0 \\
8.528,0 \\
8.320,0 \\
7.592,0 \\
7.488,0\end{array}$ \\
\hline 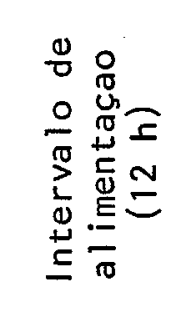 & $\begin{array}{l}23 \% \\
26 \% \\
290^{\circ} \\
32 \% \\
350 \\
38 \% \\
40 \%\end{array}$ & $\begin{array}{l}7,49 \\
7,32 \\
7,16 \\
7,08 \\
7,40 \\
7,19 \\
7,17\end{array}$ & $\begin{array}{l}7,50 \\
7,36 \\
7,33 \\
7,10 \\
7,12 \\
7,06 \\
7,19\end{array}$ & $\begin{array}{l}2.025,6 \\
2.532,0 \\
3.326,7 \\
3.198,7 \\
2.559,0 \\
2.686,9 \\
2.175,4\end{array}$ & $\begin{array}{l}1.645,8 \\
2.405,4 \\
3.070,8 \\
3.710,5 \\
3.454,7 \\
2.942,9 \\
2.686,9\end{array}$ & $\begin{array}{l}7.384,0 \\
6.968,0 \\
6.552,0 \\
6.132,0 \\
6.240,0 \\
0.042,0 \\
9.192,7\end{array}$ & $\begin{array}{l}7.280,0 \\
6.968,0 \\
6.344,0 \\
6.032,0 \\
6.136,0 \\
9.042,0 \\
8.740,6\end{array}$ \\
\hline 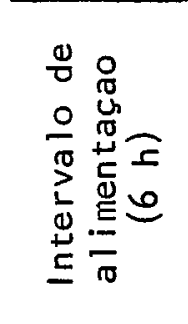 & $\begin{array}{l}43 \% \\
460 \\
49 \% \\
52 \% \\
550 \\
580 \\
60 \%\end{array}$ & $\begin{array}{l}7,20 \\
7,10 \\
7,13 \\
7,09 \\
7,06 \\
7,08 \\
7,00\end{array}$ & $\begin{array}{l}7,09 \\
6,91 \\
6,91 \\
6,89 \\
6,78 \\
6,72 \\
6,74\end{array}$ & $\begin{array}{l}1.919,3 \\
2.686,9 \\
2.303,1 \\
2.431,1 \\
2.559,0 \\
1.919,3 \\
2.431,1\end{array}$ & $\begin{array}{l}2.431,1 \\
2.559,0 \\
2.559,0 \\
2.559,0 \\
2.559,0 \\
2.686,9 \\
2.942,9\end{array}$ & $\begin{array}{l}9.042,0 \\
8.740,6 \\
9.795,5 \\
8.969,0 \\
8.740,6 \\
8.430,0 \\
8.137,8\end{array}$ & $\begin{array}{l}8.137,8 \\
8.740,6 \\
9.042,0 \\
8.430,0 \\
8.740,6 \\
8.430,0 \\
8.430,0\end{array}$ \\
\hline 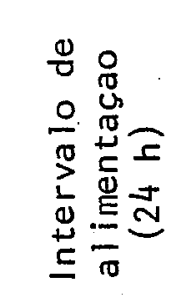 & $\begin{array}{l}63 \% \\
66 \% \\
69 \% \\
72 \% \\
75 \% \\
78 \% \\
80 \%\end{array}$ & $\begin{array}{l}6,83 \\
6,73 \\
6,47 \\
6,00 \\
5,91 \\
5,78 \\
5,70\end{array}$ & $\begin{array}{l}6,49 \\
6,30 \\
5,99 \\
6,00 \\
6,07 \\
5,80 \\
5,73\end{array}$ & $\begin{array}{l}1.989,2 \\
3.978,5 \\
5.967,7 \\
6.510,2 \\
5.967,7 \\
5.967,7 \\
6.148,6\end{array}$ & $\begin{array}{l}3.466,0 \\
4.159,3 \\
6.148,6 \\
6.691,1 \\
5.606,0 \\
5.967,7 \\
6.148,6\end{array}$ & $\begin{array}{l}8.249,0 \\
7.707,0 \\
7.006,0 \\
6.441,0 \\
7.032,0 \\
7.006,0 \\
6.893,0\end{array}$ & $\begin{array}{l}8.249,0 \\
7.458,0 \\
6.780,0 \\
6.215,0 \\
6.554,0 \\
6.893,0 \\
6.554,0\end{array}$ \\
\hline
\end{tabular}


Tabela 10: Remoção de DQO obtida na digestão anaeróbica do soro de queijo utilizando uma carga diāria de $5,38 \mathrm{~g}$ DQO nos biodigestores 1 e 2 .

\begin{tabular}{|c|c|c|c|c|c|}
\hline \multirow{2}{*}{$\begin{array}{l}\text { Tempo de } \\
\text { retenção }\end{array}$} & \multirow{2}{*}{ Dia } & \multicolumn{2}{|c|}{ Biodigestor 1} & \multicolumn{2}{|c|}{ Biodigestor 2} \\
\hline & & g DQO removida & \% remoção & g DQO removida & \% remoção \\
\hline 10 & $\begin{array}{r}0 \% \\
3 \% \\
6 \% \\
9 \% \\
12 \% \\
15 \% \\
18 \% \\
20 \%\end{array}$ & $\begin{array}{c}- \\
12,1 \\
16,1 \\
16,1 \\
13,2 \\
12,8 \\
12,4 \\
10,8\end{array}$ & $\begin{array}{r}- \\
74,7 \\
100,0 \\
100,0 \\
81,7 \\
79,5 \\
77,1 \\
100,0\end{array}$ & $\begin{array}{r}- \\
11,3 \\
14,0 \\
16,1 \\
7,0 \\
4,7 \\
16,1 \\
10,8\end{array}$ & $\begin{array}{r}- \\
70,0 \\
86,9 \\
100,0 \\
43,6 \\
29,2 \\
100,0 \\
100,0\end{array}$ \\
\hline 29 & $\begin{array}{l}23 ! \\
26 ! \\
29 \% \\
32 \% \\
35 \% \\
38 \% \\
40 \%\end{array}$ & $\begin{array}{r}16,1 \\
12,2 \\
16,1 \\
6,1 \\
15,0 \\
13,3 \\
10,8\end{array}$ & $\begin{array}{r}100,0 \\
75,8 \\
100,0 \\
38,0 \\
90,7 \\
82,5 \\
91,3\end{array}$ & $\begin{array}{r}16,1 \\
16,1 \\
16,1 \\
9,0 \\
16,1 \\
6,4 \\
10,8\end{array}$ & $\begin{array}{r}100,0 \\
100,0 \\
100,0 \\
55,8 \\
100,0 \\
39,9 \\
100,0\end{array}$ \\
\hline 39 & $\begin{array}{l}43 \% \\
46 \% \\
49 \% \\
52 \% \\
55 \% \\
58 \% \\
60 \%\end{array}$ & $\begin{array}{l}16,1 \\
16,1 \\
15,8 \\
15,6 \\
15,0 \\
16,1 \\
10,5\end{array}$ & $\begin{array}{r}100,0 \\
100,0 \\
97,5 \\
96,9 \\
92,7 \\
100,0 \\
94,8\end{array}$ & $\begin{array}{l}16,1 \\
16,1 \\
14,4 \\
13,8 \\
16,1 \\
16,1 \\
10,8\end{array}$ & $\begin{array}{r}100,0 \\
100,0 \\
89,5 \\
85,7 \\
100,0 \\
100,0 \\
100,0\end{array}$ \\
\hline 49 & $\begin{array}{l}63 \% \\
66 \% \\
69 \% \\
72 \% \\
75 \% \\
78 \% \\
809\end{array}$ & $\begin{array}{r}14,4 \\
10,6 \\
10,9 \\
6,1 \\
4,1 \\
4,4 \\
5,3\end{array}$ & $\begin{array}{l}89,3 \\
65,5 \\
67,6 \\
37,9 \\
25,4 \\
27,3 \\
32,9\end{array}$ & $\begin{array}{r}10,6 \\
9,3 \\
10,0 \\
8,4 \\
3,8 \\
9,7 \\
6,9\end{array}$ & $\begin{array}{l}65,8 \\
57,8 \\
62,1 \\
52,2 \\
23,6 \\
60,2 \\
43,0\end{array}$ \\
\hline
\end{tabular}


TTabela 11: Remoção de DQO obtida na digestão anaeróbica do soro de queijo utilizando uma carga diāria de $5,38 \mathrm{~g}$ DQO nos biodigestores 3 e 4 .

\begin{tabular}{|c|c|c|c|c|c|}
\hline \multirow{2}{*}{$\begin{array}{l}\text { Tempo de } \\
\text { retenção }\end{array}$} & \multirow{2}{*}{ Dia } & \multicolumn{2}{|c|}{ Biodigestor 3} & \multicolumn{2}{|c|}{ Biodigestor 4} \\
\hline & & g DQO removida & $\%$ remoção & g DQO removida & $\%$ remoção \\
\hline 19 & $\begin{array}{r}0 \% \\
3 \% \\
6 \% \\
9 \% \\
12 \% \\
15 \% \\
18 \% \\
20 \%\end{array}$ & $\begin{array}{r}- \\
15,6 \\
16,1 \\
16,1 \\
9,1 \\
5,8 \\
16,1 \\
10,6\end{array}$ & $\begin{array}{r}- \\
96,9 \\
100,0 \\
100,0 \\
56,5 \\
36,0 \\
100,0 \\
65,8\end{array}$ & $\begin{array}{r}- \\
16,1 \\
16,1 \\
16,1 \\
9,2 \\
10,7 \\
8,7 \\
10,6\end{array}$ & $\begin{array}{c}- \\
100,0 \\
100,0 \\
100,0 \\
57,1 \\
66,5 \\
54,0 \\
100,0\end{array}$ \\
\hline 29 & $\begin{array}{l}23 \% \\
26 \% \\
29 \% \\
32 \% \\
35 \% \\
38 \% \\
40 \%\end{array}$ & $\begin{array}{r}16,1 \\
14,2 \\
16,1 \\
9,0 \\
12,2 \\
10,3 \\
10,6\end{array}$ & $\begin{array}{r}100,0 \\
88,2 \\
100,0 \\
55,9 \\
75,8 \\
64,0 \\
100,0\end{array}$ & $\begin{array}{l}16,1 \\
16,1 \\
16,1 \\
12,4 \\
12,7 \\
12,2 \\
10,6\end{array}$ & $\begin{array}{r}100,0 \\
100,0 \\
100,0 \\
77,0 \\
78,9 \\
75,8 \\
100,0\end{array}$ \\
\hline 39 & $\begin{array}{l}43 \% \\
46 \% \\
49 \circ \\
52 \% \\
55 \% \\
58 \% \\
60 \%\end{array}$ & $\begin{array}{l}16,1 \\
13,9 \\
16,1 \\
14,5 \\
16,1 \\
16,1 \\
10,6\end{array}$ & $\begin{array}{r}100,0 \\
86,3 \\
100,0 \\
90,1 \\
100,0 \\
100,0 \\
100,0\end{array}$ & $\begin{array}{l}14,5 \\
15,5 \\
16,1 \\
16,1 \\
15,9 \\
15,9 \\
10,6\end{array}$ & $\begin{array}{r}90,3 \\
96,3 \\
100,0 \\
100,0 \\
98,8 \\
98,8 \\
100,0\end{array}$ \\
\hline 40 & $\begin{array}{l}63 \% \\
660 \\
69 \circ \\
72 \% \\
75 \circ \\
78 \% \\
80 \%\end{array}$ & $\begin{array}{r}11,4 \\
12,0 \\
10,9 \\
10,8 \\
11,6 \\
9,4 \\
8,2\end{array}$ & $\begin{array}{l}70,8 \\
74,5 \\
67,7 \\
67,1 \\
72,1 \\
58,4 \\
50,9\end{array}$ & $\begin{array}{r}11,8 \\
13,4 \\
12,0 \\
12,6 \\
11,7 \\
10,9 \\
8,6\end{array}$ & $\begin{array}{l}73,3 \\
83,2 \\
74,5 \\
78,3 \\
72,7 \\
67,7 \\
60,3\end{array}$ \\
\hline
\end{tabular}


Tabela 12: Remóãa de DQO otbida na digestão anaeróbica do soro de queijo utilizando uma carga diāria de $5,38 \mathrm{~g}$ DQO nos biodigestores 5 e 6 .

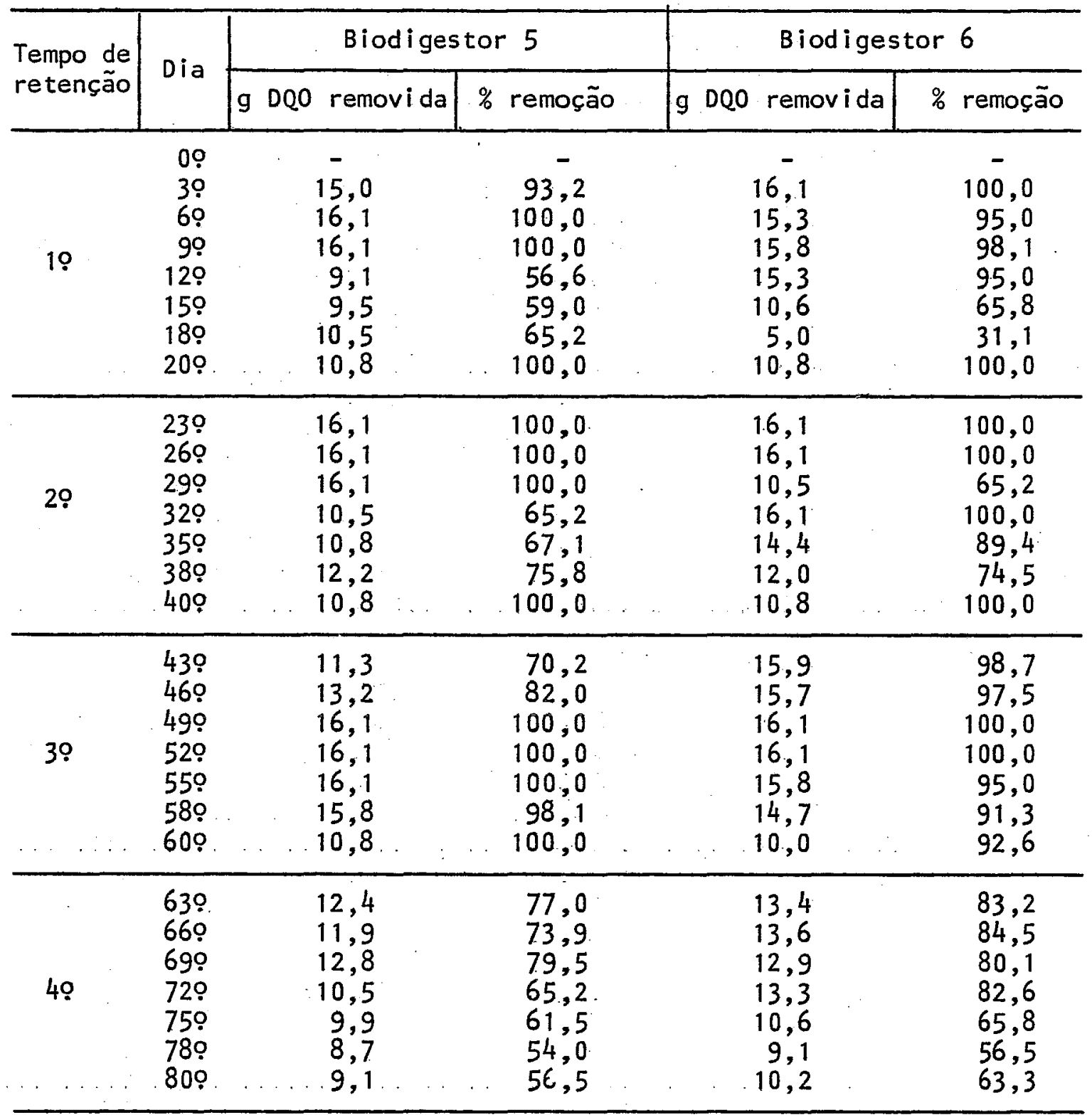


Tabela 13: Produção de biogās. (1) nos biodigestores 1, 2, 3 , 4,5 e 6 mantidos à temperatura de $35^{\circ} \mathrm{C}$ e alimentados com $5,38 \mathrm{~g}$ DQO/dia no primeiro tempo de retenção.

\begin{tabular}{r|c|c|c|c|c|c}
\hline Dia & $\begin{array}{c}\text { Biodiges- } \\
\text { tor } 1\end{array}$ & $\begin{array}{c}\text { Biodiges- } \\
\text { tor } 2\end{array}$ & $\begin{array}{c}\text { Biodiges- } \\
\text { tor } 3\end{array}$ & $\begin{array}{c}\text { Biodiges- } \\
\text { tor } 4\end{array}$ & $\begin{array}{c}\text { Biodiges- } \\
\text { tor } 5\end{array}$ & $\begin{array}{c}\text { Biodiges- } \\
\text { tor } 6\end{array}$ \\
\hline 19 & - & - & - & - & - & - \\
29 & 1,78 & 1,32 & 1,75 & 1,85 & 1,87 & 1,73 \\
39 & 1,98 & 1,66 & 2,36 & 2,24 & 2,23 & 1,97 \\
49 & 1,81 & 1,65 & 2,23 & 2,09 & 2,21 & 1,97 \\
59 & 1,96 & 1,64 & 2,48 & 2,50 & 2,51 & 2,02 \\
69 & 2,12 & 1,64 & 2,18 & 2,22 & 2,35 & 2,13 \\
79 & 2,07 & 1,62 & 2,55 & 2,56 & 2,65 & 2,31 \\
89 & 2,15 & 1,64 & 2,73 & 2,89 & 2,58 & 2,11 \\
99 & 2,38 & 1,90 & 2,83 & 2,86 & 2,43 & 2,30 \\
109 & 2,42 & 2,20 & 2,72 & 2,80 & 2,36 & 2,13 \\
119 & 2,25 & 1,86 & 2,74 & 2,79 & 2,36 & 2,06 \\
129 & 2,40 & 1,92 & 2,68 & 2,70 & 2,40 & 2,27 \\
139 & 2,20 & 1,85 & 2,64 & 2,69 & 2,40 & 2,23 \\
149 & 2,15 & 1,92 & 2,55 & 2,57 & 2,53 & 2,10 \\
159 & 2,11 & 1,90 & 2,63 & 2,69 & 2,66 & 2,25 \\
169 & 2,15 & 1,95 & 3,11 & 2,89 & 2,64 & 2,30 \\
179 & 1,91 & 1,89 & 2,69 & 2,72 & 2,59 & 2,42 \\
189 & 2,37 & 2,19 & 2,78 & 2,70 & 2,70 & 2,29 \\
199 & 2,28 & 2,09 & 2,64 & 2,78 & 2,59 & 2,33 \\
209 & 2,14 & 1,97 & 2,39 & 2,52 & 2,56 & 2,13 \\
\hline Tota1 & 40,64 & 34,81 & 48,68 & 49,06 & 46,62 & 41,05 \\
\hline
\end{tabular}


Tábela 14: Produção de biogás (1) nos biodigestores $1,2,3$, 4,5 e 6 mantidos à temperatura de $35^{\circ} \mathrm{C}$ e alimentados com $5,38 \mathrm{~g}$ DQO/dia no primeiro tempo de retenção.

\begin{tabular}{c|c|c|c|c|c|c}
\hline Dia & $\begin{array}{c}\text { Biodiges- } \\
\text { tor } 1\end{array}$ & $\begin{array}{c}\text { Biodiges- } \\
\text { tor } 2\end{array}$ & $\begin{array}{c}\text { Biodiges- } \\
\text { tor } 3\end{array}$ & $\begin{array}{c}\text { Biodiges- } \\
\text { tor } 4\end{array}$ & $\begin{array}{c}\text { Biodiges- } \\
\text { tor } 5\end{array}$ & $\begin{array}{c}\text { Biodiges- } \\
\text { tor } 6\end{array}$ \\
\hline 219 & 2,20 & 2,01 & 2,40 & 2,63 & 2,59 & 2,49 \\
229 & 2,29 & 1,94 & 2,33 & 2,46 & 2,43 & 2,17 \\
239 & 2,28 & 2,06 & 2,46 & 2,56 & 2,44 & 2,43 \\
249 & 2,25 & 2,03 & 2,51 & 2,45 & 2,34 & 2,30 \\
259 & 2,23 & 2,01 & 2,51 & 2,50 & 2,38 & 2,23 \\
269 & 2,38 & 2,15 & 2,59 & 2,58 & 2,54 & 2,32 \\
279 & 2,23 & 2,07 & 2,48 & 2,41 & 2,40 & 2,27 \\
289 & 2,20 & 2,02 & 2,59 & 2,73 & 2,40 & 2,33 \\
299 & 2,23 & 2,03 & 2,45 & 2,57 & 2,31 & 2,30 \\
309 & 2,15 & 1,93 & 2,58 & 2,68 & 2,39 & 2,17 \\
319 & 1,90 & 1,78 & 2,23 & 2,41 & 2,30 & 1,94 \\
329 & 2,10 & 1,95 & 2,48 & 2,73 & 2,70 & 2,30 \\
339 & 1,99 & 1,79 & 2,27 & 2,54 & 2,46 & 1,98 \\
349 & 2,05 & 1,85 & 2,34 & 2,50 & 2,48 & 2,10 \\
359 & 2,10 & 1,93 & 2,47 & 2,48 & 2,58 & 2,20 \\
369 & 1,82 & 1,63 & 2,09 & 2,17 & 2,33 & 2,15 \\
379 & 1,89 & 1,76 & 2,11 & 2,08 & 2,36 & 2,13 \\
389 & 1,85 & 1,58 & 2,19 & 2,02 & 2,28 & 2,13 \\
399 & 1,80 & 1,56 & 2,30 & 1,98 & 2,38 & 2,10 \\
409 & 1,81 & 1,60 & 2,16 & 1,80 & 2,46 & 1,94 \\
\hline Total & 41,75 & 37,68 & 47,54 & 45,72 & 48,55 & 43,98 \\
\hline
\end{tabular}


Tábela 15: Produção de biogás (1) nos biodigestores 1, 2, 3, 4,5 e 6 mantidos à temperatura de $35^{\circ} \mathrm{C}$ e alimentados com $5,38 \mathrm{~g} \mathrm{DQO/dia}$ no primeiro tempo de retenção.

\begin{tabular}{|c|c|c|c|c|c|c|}
\hline Dia & $\begin{array}{c}\text { Biodiges- } \\
\text { tor } 1\end{array}$ & $\begin{array}{c}\text { Biodiges- } \\
\text { tor } 2\end{array}$ & $\begin{array}{c}\text { Biodiges - } \\
\text { tor. } 3\end{array}$ & $\begin{array}{c}\text { Biodiges- } \\
\text { tor } 4\end{array}$ & $\begin{array}{c}\text { Biodiges- } \\
\text { tor } 5\end{array}$ & $\begin{array}{c}\text { Biodiges- } \\
\text { tor } 6\end{array}$ \\
\hline 419 & 1,70 & 1,35 & 2,11 & 1,53 & 2,08 & 1,97 \\
\hline 429 & 1,68 & 1,38 & 2,19 & 1,69 & 2,10 & $2,0.0$ \\
\hline 439 & 1,62 & 1,34 & 2,11 & 1,80 & 2,14 & 1,98 \\
\hline 449 & 1,54 & 1,40 & 1,94 & 1,84 & 2,17 & 2,00 \\
\hline 459 & 1,39 & 1,31 & 1,92 & 1,88 & 2,05 & 1,83 \\
\hline 469 & $1,2.0$ & 1,27 & 1,91 & 2,00 & 2,11 & 2,02 \\
\hline $47 ?$ & 1,11 & 1,21 & 1,87 & 1,85 & 2,12 & 2,00 \\
\hline 480 & 1,14 & 1,34 & 1,98 & 1,95 & 2,11 & 2,00 \\
\hline 490 & 1,00 & 1,31 & 1,92 & 2,02 & 2,12 & 1,97 \\
\hline 509 & 0,95 & 1,21 & 1,87 & 1,99 & 2,03 & 1,81 \\
\hline 510 & 1,14 & 1,33 & 1,90 & 2,11 & 2,11 & 1,87 \\
\hline 529 & 1,20 & 1,48 & 1,98 & 2,15 & 2,24 & 1,94 \\
\hline 539 & 1,07 & 1,43 & 1,94 & 2,11 & 2,18 & 1,79 \\
\hline 540 & 1,11 & 1,46 & 1,95 & 2,10 & 2,20 & 1,82 \\
\hline 550 & 1,09 & 1,40 & 2,00 & 2,01 & 2,15 & 1,90 \\
\hline 560 & 1,15 & 1,42 & 2,01 & 1,96 & 2,18 & 1,95 \\
\hline $570^{\circ}$ & 1,13 & 1,29 & 1,97 & 2,04 & 2,21 & 2,00 \\
\hline 580 & 1,10 & 1,20 & 1,93 & 2,10 & 2,20 & 2,01 \\
\hline 590 & 1,05 & 1,23 & 1,89 & 2,15 & 2,11 & 1,95 \\
\hline 609 & 1,00 & 1,20 & 1,90 & 2,10 & 2,13 & 1,99 \\
\hline Total & 24,37 & 26,56 & 39,29 & 39,38 & 42,74 & 38,80 \\
\hline
\end{tabular}


Tábela 16: Produção de biogãs (1) nos biodigestores $1,2,3$, 4,5 e 6 mantidos à temperatura de $35^{\circ} \mathrm{C}$ e alimentados com $5,38 \mathrm{~g}$ DQO/dia no primeiro tempo de retenção.

\begin{tabular}{ccc|c|c|c|c}
\hline Dia & $\begin{array}{c}\text { Biodiges- } \\
\text { tor } 1\end{array}$ & $\begin{array}{c}\text { Biodiges- } \\
\text { tor } 2\end{array}$ & $\begin{array}{c}\text { Biodiges- } \\
\text { tor } 3\end{array}$ & $\begin{array}{c}\text { Biodiges- } \\
\text { tor } 4\end{array}$ & $\begin{array}{c}\text { Biodiges- } \\
\text { tor } 5\end{array}$ & $\begin{array}{c}\text { Biodiges- } \\
\text { tor } 6\end{array}$ \\
\hline 619 & 0,99 & 0,93 & 1,61 & 1,91 & 1,74 & 1,12 \\
629 & 1,70 & 1,85 & 2,11 & 2,39 & 2,11 & 2,11 \\
639 & 1,57 & 1,87 & 2,23 & 2,46 & 2,23 & 2,22 \\
649 & 1,67 & 1,84 & 2,24 & 2,54 & 2,32 & 2,23 \\
659 & 1,68 & 1,83 & 2,26 & 2,46 & 2,26 & 2,13 \\
669 & 1,03 & 0,91 & 2,20 & 2,40 & 2,24 & 2,24 \\
679 & 0,64 & 1,24 & 2,05 & 2,49 & 2,06 & 2,09 \\
689 & 0,92 & 1,35 & 2,06 & 2,44 & 2,02 & 1,96 \\
699 & 0,79 & 1,05 & 1,98 & 2,37 & 1,89 & 1,99 \\
709 & 0,51 & 0,83 & 1,67 & 2,26 & 1,82 & 1,74 \\
719 & 0,62 & 0,89 & 2,10 & 2,15 & 1,98 & 1,93 \\
729 & 0,60 & 0,83 & 2,00 & 2,20 & 1,99 & 1,95 \\
739 & 0,54 & 0,32 & 1,23 & 1,76 & 1,41 & 1,61 \\
749 & 0,70 & 0,52 & 1,25 & 1,71 & 1,53 & 1,58 \\
759 & 0,73 & 0,31 & 1,03 & 1,70 & 1,63 & 1,72 \\
769 & 0,62 & 0,16 & 0,63 & 1,56 & 1,46 & 1,70 \\
779 & 0,66 & 0,10 & 1,01 & 1,46 & 1,30 & 1,59 \\
789 & 0,51 & - & 1,10 & 1,40 & 1,42 & 1,58 \\
799 & 0,42 & 0,09 & 0,98 & 1,20 & 1,32 & 1,41 \\
809 & 0,48 & 0,12 & 0,86 & 1,10 & 1,28 & 1,40 \\
\hline Tota1 & 17,38 & 17,04 & 32,60 & 39,96 & 26,41 & 36,30 \\
\hline & & & & & & \\
\hline
\end{tabular}


Tabela 17: Eficiência da digestão anaeróbica de soro de queijo sem correção de $\mathrm{pH}$ a $35^{\circ} \mathrm{C}$ (Biodigestores 1 e 2 )

\begin{tabular}{|c|c|c|c|c|c|c|c|c|c|c|c|c|c|}
\hline \multirow{2}{*}{$\begin{array}{l}\text { Tempo de } \\
\text { retenção } \\
\text { (dia) }\end{array}$} & \multirow{2}{*}{$\begin{array}{c}\text { Carga adici } \\
\text { onada aos } \\
\text { biodig. } \\
(g \text { DQO })\end{array}$} & \multicolumn{2}{|c|}{$\begin{array}{l}\text { Produção de biogās } \\
\text { (1) }\end{array}$} & \multicolumn{2}{|c|}{ Remoçäo de DQO (\%) } & \multicolumn{2}{|c|}{$\begin{array}{c}1 \text { biogäs produzido/ } \\
\text { /g DQO removida }\end{array}$} & \multicolumn{2}{|c|}{$\begin{array}{c}\text { Valor de } \mathrm{CH}_{4} \text { no } \\
\text { biogäs (1) }\end{array}$} & \multicolumn{2}{|c|}{$\begin{array}{lll}\text { Valor teörico de } & \mathrm{CH}_{4} \\
\text { em rel.ä remoşão } & D Q O\end{array}$} & \multicolumn{2}{|c|}{ Eficiência $(\%)$} \\
\hline & & Biod. 1 & Biod. 2 & Biod. 1 & Biod. 2 & Biod. 1 & Biod. 2 & Biod. 1 & Biod. 2 & Biod. 1 & Biod. 2 & Biod. 1 & Biod. 2 \\
\hline $\begin{array}{c}19 \\
(19-209)\end{array}$ & 107,6 & 40,6 & 34,8 & 87,6 & 75,7 & 0,43 & 0,43 & 13,4 & 10,3 & 33,0 & 28,5 & 40,6 & 36,2 \\
\hline $\begin{array}{c}29 \\
(219-409)\end{array}$ & 107,6 & 41,8 & 37,7 & 82,6 & 85,1 & 0,47 & 0,41 & 13,5 & 10,9 & 31,1 & 32,0 & 43,4 & 25,1 \\
\hline $\begin{array}{c}39 \\
(419-609)\end{array}$ & 107,6 & 24,4 & 26,6 & 97,4 & 96,6 & 0,23 & 0,26 & 7,1 & 8,0 & 36,5 & 36,2 & 19,6 & 22,1 \\
\hline $\begin{array}{c}49 \\
(61.9-809)\end{array}$ & 107,6 & 17,4 & 17,0 & 49,4 & $\begin{array}{l}52,1 \\
\bar{x} \pm s\end{array}$ & $\begin{array}{c}0,33 \\
0,37 \pm 0,10\end{array}$ & $\begin{array}{c}0,30 \\
0,35 \pm 0,07\end{array}$ & 3,1 & 3,8 & 18,5 & 19,6 & 16,8 & 22,6 \\
\hline
\end{tabular}




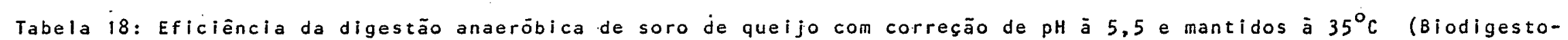
res 3 e 4).

\begin{tabular}{|c|c|c|c|c|c|c|c|c|c|c|c|c|c|}
\hline \multirow{2}{*}{$\begin{array}{l}\text { Tempo de } \\
\text { retenção } \\
\text { (dia) }\end{array}$} & \multirow{2}{*}{$\begin{array}{c}\text { Carga adici } \\
\text { onada aos } \\
\text { biodig. } \\
\text { (g DQO) }\end{array}$} & \multicolumn{2}{|c|}{$\begin{array}{l}\text { Produçao de biogās } \\
\text { (1) }\end{array}$} & \multicolumn{2}{|c|}{ Remoção de $D Q 0$ (\%) } & \multicolumn{2}{|c|}{$\begin{array}{c}1 \text { biogās produzido/ } \\
\text { /g DQO removida }\end{array}$} & \multicolumn{2}{|c|}{$\begin{array}{l}\text { Valor de } \mathrm{CH}_{4} \text { no } \\
\text { biogás (1) }\end{array}$} & \multicolumn{2}{|c|}{$\begin{array}{l}\text { Valor teörico de } \mathrm{CH}_{4} \\
\text { em rel.à remoşão } \mathrm{DQO}^{2}\end{array}$} & \multicolumn{2}{|c|}{ Eficiēncia (\%) } \\
\hline & & Biod. 3 & Biod. 4 & Biod. 3 & Biod. 4 & Biod. 3 & Biod. 4 & Biod. 3 & Biod. 4 & Biod. 3 & Biod. 4 & Biod. 3 & Biod. 4 \\
\hline $\begin{array}{c}19 \\
(19-209)\end{array}$ & 107,6 & 48,7 & 49,1 & 79,3 & 82,5 & 0,57 & 0,55 & 15,8 & 17,3 & 29,7 & 31,3 & 53,2 & 55,3 \\
\hline $\begin{array}{c}29 \\
(219-409)\end{array}$ & 107,6 & 47,5 & 45,7 & 83,4 & 90,2 & 0,53 & 0,47 & 15,3 & 16,4 & 31,3 & 33,9 & $.48,9$ & 33,5 \\
\hline $\begin{array}{c}39 \\
(419-609)\end{array}$ & 107,6 & 39,3 & 39,4 & 96,6 & 97,7 & 0,38 & 0,38 & 13,9 & 11,8 & 36,5 & 36,9 & 38,1 & 31,0 \\
\hline $\begin{array}{c}49 \\
(619-809)\end{array}$ & 107,6 & 32,6 & 40,0 & 65,9 & $\begin{array}{l}74,0 \\
\bar{x} \pm s\end{array}$ & $\begin{array}{c}0,46 \\
0,49 \pm 0,07\end{array}$ & $\begin{array}{c}0,50 \\
0,48 \pm 0,06\end{array}$ & 7,8 & 9,2 & 24,9 & 27,9 & 31,3 & 29,4 \\
\hline
\end{tabular}


Tabela 17: Eficlência da digestão anaerōbica de soro de queijo sem correção de pH à $35^{\circ} \mathrm{C}$ (Biodigestores 1 e 2 )

\begin{tabular}{|c|c|c|c|c|c|c|c|c|c|c|c|c|c|}
\hline \multirow{2}{*}{$\begin{array}{l}\text { Tempo de } \\
\text { retenção } \\
\text { (dia) }\end{array}$} & \multirow{2}{*}{$\begin{array}{l}\text { Carga adici } \\
\text { onada aos } \\
\text { biodig. } \\
(g \text { DQO })\end{array}$} & \multicolumn{2}{|c|}{$\begin{array}{l}\text { Produção de biogäs } \\
\text { (1) }\end{array}$} & \multicolumn{2}{|c|}{ Remoção de DQO (\%) } & \multicolumn{2}{|c|}{$\mid \begin{array}{c}1 \text { biogäs produzido/ } \\
/ g \text { DQO removida }\end{array}$} & \multicolumn{2}{|c|}{$\begin{array}{l}\text { Valor de } \mathrm{CH}_{4} \text { no } \\
\text { biogäs (1) }\end{array}$} & \multicolumn{2}{|c|}{$\begin{array}{l}\text { Valor teörico de } \mathrm{CH}_{4} \\
\text { em rel.ä remoção } \mathrm{DQO}\end{array}$} & \multicolumn{2}{|c|}{ Eficiência (\%) } \\
\hline & & Biod. 1 & Biod. 2 & Biod. 1 & Biod. 2 & Biod. 1 & Biod. 2 & Biod. 1 & Biod. 2 & Biod. 1 & Biod. 2 & Biod. 1 & Biod. 2 \\
\hline $\begin{array}{c}19 \\
(19-209)\end{array}$ & 107,6 & 40,6 & 34,8 & 87,6 & 75,7 & 0,43 & 0,43 & 13,4 & 10,3 & 33,0 & 28,5 & 40,6 & 36,2 \\
\hline$\frac{2 \%}{(219-40 \%)}$ & $.107,6$ & 41,8 & 37,7 & 82,6 & 85,1 & 0,47 & 0,41 & 13,5 & 10,9 & 31,1 & 32,0 & $43,4^{\circ}$ & 25,1 \\
\hline $\begin{array}{c}39 \\
(419-609)\end{array}$ & 107,6 & 24,4 & 26,6 & 97,4 & 96,6 & 0,23 & 0,26 & 7,1 & 8,0 & 36,5 & 36,2 & 19,6 & 22,1 \\
\hline $\begin{array}{c}49 \\
(619-809)\end{array}$ & 107,6 & 17,4 & 17,0 & 49,4 & $\begin{array}{l}52,1 \\
\bar{x} \pm 5\end{array}$ & $\begin{array}{c}0,33 \\
0,37 \pm 0,10\end{array}$ & $\begin{array}{c}0,30 \\
0,35 \pm 0,07\end{array}$ & 3,1 & 3,8 & 18,5 & 19,6 & 16,8 & 22,6 \\
\hline
\end{tabular}


Tabela 20: Remoção total de DQO em cada TR mantidos à $35^{\circ} \mathrm{C}$ e utilizando $5,38 \mathrm{~g}$ DQO/ /dia.

\begin{tabular}{c|c|c|c|c|c}
\hline Digestores & IOTR & 29TR & $39 T R$ & $49 T R$ & $\bar{x} \pm S$ \\
\hline 1 & 87,6 & 82,6 & 97,4 & 49,4 & $79,3 \pm 18,0$ \\
2 & 75,7 & 85,1 & 96,6 & 52,1 & $77,4 \pm 16,4$ \\
\hline 3 & 79,3 & 83,4 & 96,6 & 65,9 & $81,3 \pm 11,4$ \\
4 & 82,5 & 90,2 & 97,7 & 74,0 & $86,1 \pm 8,8$ \\
\hline 5 & 82,0 & 86,9 & 92,5 & 66,8 & $82,1 \pm 9,6$ \\
6 & 83,6 & 89,9 & 96,4 & 73,7 & $85,9 \pm 8,4$ \\
\hline
\end{tabular}

